\title{
George French Angas and the Creation of Colonial Knowledge in New Zealand
}

\author{
Catherine Falconer-Gray
}

A thesis submitted to Victoria University of Wellington in fulfilment of the requirements for the degree of Master of Arts in History

Victoria University of Wellington 

To Michael Kingston

For Everything, Always 

Abstract

In 1844, George French Angas, the English traveller, artist, natural historian and ethnographer spent four months travelling in New Zealand. He sought out and met many of the most influential Maori leaders of the time, sketching and recording his observations as he went. His stated intention was to provide a 'more correct idea' of New Zealand and the New Zealanders. In Australia and then Britain he held exhibitions of his work and in 1847 he published two works based on this time in New Zealand: a large volume of fullcolour lithographs, The New Zealanders Illustrated and a travel narrative based on his journal, Savage Life and Scenes in Australia and New Zealand. These exhibitions and publications comprised the nineteenth century's largest collection of works about Maori and Maori culture.

This thesis is a study of the 'more correct idea' that Angas sought to provide: his creation of colonial knowledge about Maori. Angas is most commonly described in New Zealand as being an unremarkable artist but as providing a window onto New Zealand in the 1840s. This thesis opens the window wider by looking at Angas's works as a record of a cultural encounter and the formation of a colonial identity. The works were shaped by numerous ideological and intellectual currents from Britain and the empire, including humanitarianism and the aesthetic of the picturesque. Ideas about gender and the body form a central part of the colonial knowledge created in Angas's work. Particularly notable is what this thesis terms 'sartorial colonisation' - a process of colonisation through discourse and expectations around clothes.

Angas also travelled and worked in a dynamic middle ground in New Zealand and Maori played a vital role in the creation of his works. Angas represented Maori in a sympathetic light in many ways. Ultimately however, he believed in the superiority of the British culture, to the detriment of creating colonial knowledge that placed Maori as equal partners in the recently signed Treaty of Waitangi. This thesis also examines the ways in which Angas's body of work has been engaged with by the New Zealand public through to the present. As a study of the products of a British traveller who spent time in other parts of the empire as well as in New Zealand, this thesis contributes to histories of New Zealand, and British imperial and transcolonial history. 

List of Plates and Figures vii

Abbreviations $\quad$ ix

Introduction 1

Chapter One

'Wandering on the outskirts of civilisation': The Traveller

Chapter Two

'A writer of images': The Artist

Chapter Three

'A faithful describer': The Natural Historian \& Ethnographer

Chapter Four

'Aged but Vivid: Angas's Work into the Present

Conclusion 


\section{Acknowledgments}

First and foremost, my acknowledgments and gratitude go to my supervisor Professor Charlotte Macdonald for her guidance, enthusiasm and encouragement. Her insightful feedback has always challenged and extended me in my studies generally, and in this project particularly.

My thanks also go to all the people who have helped and inspired me in various ways while this thesis has been in production:

To the staff and postgraduates in the History programme at Victoria University of Wellington, for a stimulating and supportive environment. In particular I would like to thank Adam, Alex, Carl, Coralie, Daniel, Dayton, Elizabeth, Florence, Grace, Hannah, Leigh, Matthew, Owen, Rachel and Susann for friendship and inspiration. To Associate Professor Roger Blackley of the Art History programme for so generously answering all my Art History questions.

To my amazing and supportive parents Sally and Stephen, and my brothers Michael, Richard and Phillip who have as always been beside me all the way, helping in all sorts of ways. To my partner at the beginning of the journey, Mike Kingston, and to my partner at the end of the journey, Ben Kilgore. To my wonderful friends and flatmates who have let me go on endlessly about how exciting history is, and how hard writing it is. Special thanks go to Nellie Ralston, Joseph Nichols, Andrew Morrison, Peter Fernando, and Nola Wicks without whom this thesis would never have been completed.

To the first historian I encountered, Richard Webb, for igniting my love of history at Queen's High School and to all the historians whose work continues to inspire and challenge me.

I am very grateful to Victoria University of Wellington for a Masters by Thesis Scholarship and the Bowen Prize which helped to fund this project, and for a Faculty Research Grant which allowed me to do research in Australia. My gratitude also goes to the staff at the Victoria University Library (especially Justin Cargill and the Beaglehole Room librarians), the National Library of New Zealand, the National Library of Australia, the State Library of South Australia, the Auckland City Central Library, the National Gallery of Australia, the Art Gallery of South Australia, the Auckland Art Gallery, and the South Australia Museum (particularly Helen Hopper and Philip Jones). 
1. 'Mr G. French Angas's New Zealand and Australian exhibition,' Exhibition handbill advertisement.

2. 'George French Angas,' oil, unknown artist.

3. 'New Zealand Itinerary, 1844, of George French Angas', G.C.

Petersen and S.M. Mead.

4. 'George French Angas', lithograph, Charles Baugniet.

5. 'Te Wherowhero or Patuatu (Potatau): The Principal Chief of all Waikato', lithograph, George French Angas.

6. 'Waingaroa. Te Moanaroa (Stephen). Te Awaitaia (William Naylor)', lithograph, W. Hawkins and George French Angas.

7. 'Aisha', Heath's Book of Beauty.

8. 'E Wai. Wife of Tuarau the son of Na Horua or Tom Street. Kahoki. Niece of Rauparaha. and daughter of Te Wehiarangi. Chief of Roturua Lakes',watercolour, George French Angas.

9. 'E Wai and Kahoki, nieces of Rauparaha', lithograph, W. Hawkins and George French Angas.

10. 'Nga Toenga, daughter of the Barrier Island Chief', lithograph, W. Hawkins and George French Angas.

11. 'Rora Pare. (A regular vixen) Daughter of Hurakea Ngati Wauroa Tribe Domesticated at Pépépé: Oct: $2^{\text {nd }}$, watercolour, George

French Angas; 'Josiah Taonui. Nov 25 ${ }^{\text {th }}$ 1844,' watercolour, George French Angas.

12. 'Ko Nga Waka Te Karaka, (or Clark). The Christian Chief of the Nga-ti-waoroa Tribe, Waikato. And Wakauenuku, his Attendant Boy', lithograph, George French Angas.

13. 'Paratene Maioha, a Chief of Waingaroa,' lithograph, George French Angas.

14. 'Typical Portraits of the New Zealanders', lithograph, J.W. Giles and George French Angas.

15. 'New Antilope[sic] from St Lucia Bay,' [Tragelaphas Angasi], watercolour, George French Angas.

16. 'South Australian Entomology,' lithograph, W. Wing and George French Angas; 'South Australian Botany,' lithograph, W. Wing and George French Angas.

17. 'Te Rauparaha and Ko Katu', watercolour, George French Angas; 'Tamihana Te Rauparaha,' watercolour, George French Angas. 
AAGRL Auckland Art Gallery Research Library

AGSA Art Gallery of South Australia

ATL Alexander Turnbull Library

NLA National Library of Australia

SAM South Australian Museum

SLSA State Library of South Australia 



\section{Introduction}

In April 1846 an exhibition of the works of George French Angas (1822 -1886) opened at the Egyptian Hall in Piccadilly, London. For a one shilling entrance fee, the public could see 270 watercolour paintings and sketches from New Zealand and Australia, including eighty-two 'Full-Length Portraits, from Life, of the Principal New Zealand Chiefs, with their Wives and Children." Also in attendance was Hemi Pomare, a 'young New Zealand Chief in 'Costume' (see Fig. 1). The Egyptian Hall was a well-known venue for mass entertainment and this exhibition, 'under the especial patronage of the Queen and HRH Prince Albert', was described as 'one of the great Easter attractions' by the Illustrated London News. ${ }^{2}$ It was the largest public display of images of the tangata whenua of New Zealand in the nineteenth century. ${ }^{3}$ Within a year Angas also published two works about New Zealand: The New Zealanders Illustrated and Savage Life and Scenes in Australia and New Zealand. $^{4}$

The body of work which comprised the exhibition and the publications was based on a visit the twenty-one year old Angas made to New Zealand in 1844. He left London in 1843 and travelled to Adelaide in South Australia. After travelling there for six months he crossed the Tasman Sea to New Zealand, the newest of the British colonies. Landing first in the New Zealand Company settlement of Wellington in August 1844, he spent the next four months travelling by boat and on foot. From Wellington he travelled to Porirua and over the Cook Strait to Queen Charlotte Sound. The longest leg of his journey was a round trip from Auckland through the Taupo and Waikato areas. ${ }^{5}$ Travelling with his sketchbook and his journal he met, sketched, and wrote about Maori, including many of the most influential leaders of the time. He left New Zealand on 12 December, travelled for several more months in Australia then returned to London, the 'cultural centre' of empire, to exhibit and publish his images and writing. ${ }^{6}$

1 'Mr G. French Angas's New Zealand and Australian exhibition,' Exhibition handbill advertisement, London, 1846, F/Broadside F4218, National Library of Australia (NLA).

2 'The New Zealand and South Australian Exhibition,' Illustrated London News, 18 April 1846, 253.

${ }^{3}$ Leonard Bell, Colonial Constructs: European Images of Maori, 1840-1914 (Auckland: Auckland University Press, 1992), 9.

${ }^{4}$ George French Angas, The New Zealanders Illustrated (London: Thomas McLean, 1847); George French Angas, Savage

Life and Scenes in Australia and New Zealand: Being an Artist's Impressions of Countries and People at the Antipodes, vols. I and II

(London: Smith, Elder and Co., 1847).

${ }^{5}$ See 'Chapter One: "Wandering on the Outskirts of Civilisation”: The Traveller', 16, for a map of Angas's New Zealand journey.

${ }^{6}$ Tim Barringer, Geoff Quilley, and Douglas Fordham, "Introduction," in Art and the British Empire, ed. Tim Barringer, Geoff Quilley, and Douglas Fordham (Manchester: Manchester University Press, 2007), 13. 


\section{NOW OPEN, 15,6}

Under the especial patronage of the QUBEN and H.R.H. Prince ALBERT.

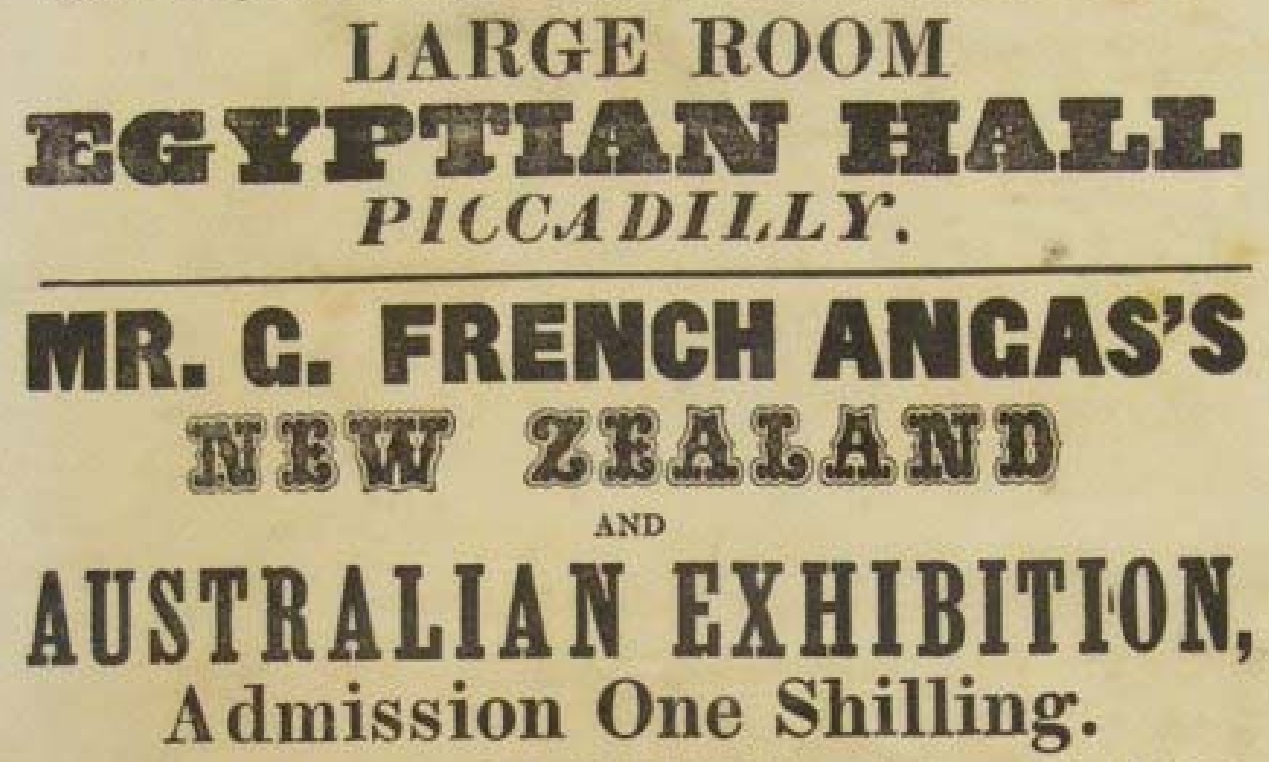

Comprising upwards of $\mathbf{2 0 0}$ Full-length Portraits, from Life, of the Principal

New Zealand Chiefs,

With their Wives and Children.

Arrongst them are fbose of Heki, Nene, or Tumiti Waka, Te Whero-whero, Pomare, William Naylor, Rauparaha, Bangihaeta, \&c., \&c., \&c., in their full native costume. Their carved buildings, colossal images, canoes, temples, houses, tombs, pahs, fortifications, dances, games, manners, customs, and entire domestic economy, autographs, tattooing, \&c.

\section{One Hundred Portraits of the Natives and Scenery of South Australia.}

Views in New South Wales, Brazil, Cape de Verdes, \&c., \&c., and a variety of other subjects. Also, a Large Collection of Costumes, Weapons, Implements, Canoes, \&c. \&c., illustrative of the natives of the above countries, and objects of natural history.

For the last three years, Mr. Angas has been travelling and living amongat the New Zealunders and Australian natives, and having devoted his pencil to the careful representation on the spot, of every object of note amongat them, his drawings and collections will be of the highest novelty and interest, tha subjects being as entertaining as they are new.

\section{A Young New Zealand Chief will attend in the Room in his Costume. \\ T. FROST, Printer, 45, Marahall Street, Golden Square.}

Figure 1: 'Mr G. French Angas's New Zealand and Australian exhibition,' Exhibition handbill advertisement, London, 1846, F/Broadside F4218, NLA. 
The New Zealanders Illustrated was a large, lavish and colourful collection of lithographs. Dedicated to His Royal Highness Prince Albert, the collection was aimed at an elite audience. Subscribers included such eminences as Her Most Gracious Majesty the Queen, the Governor of New Zealand and the Honourable the Board of the East India Company. The collection consisted of sixty full colour plates with text, thirty-one of which were full-length portraits. Landscapes and depictions of ceremonies, artefacts and architecture made up the rest. Angas published the collection in ten instalments at two monthly intervals, as was common for such productions in the nineteenth century. ${ }^{7}$ Subscribers who acquired all ten instalments had them bound into the single volume. Savage Life and Scenes, published in two volumes, was aimed at a more popular audience. It was a vibrant, entertaining and eminently readable travelogue based on Angas's journal.

Today, over 165 years later, Angas's work features prominently in the shaping of the imagination and understanding of Maori and of New Zealand in the 1840s. His images frequently illustrate books and historical displays. His writing about New Zealand, from Savage Life and Scenes and from the text of The New Zealanders, is used to detail Maori personalities and culture. ${ }^{8}$ Angas's work is treated as a window on the past and a valuable source of information. In 1975, the historian G.C. Petersen, in an expensive publication of a number of Angas's New Zealand watercolours, described his work as a 'vivid and authentic part of the historical record of New Zealand."

To provide a 'vivid and authentic' record of Maori in 1844 was Angas's intention. In the preface to The New Zealanders, he stated, 'the great change that is daily going on in [the New Zealanders'] physical and social condition, renders it necessary that a more correct idea of them should be obtained at home, than one offered by mere description'. ${ }^{10}$ This thesis treats Angas's New Zealand works that entered the public domain through exhibition and publication as a window, but one that opens onto a much wider view. Locating itself within the theoretical frameworks of new imperial history, it investigates the nature of the 'more correct idea' of Maori that Angas intended his audience to obtain. It explores his works as sites which constructed particular understandings and ways of

\footnotetext{
7 'A Catalogue of Paintings by George French Angas, illustrative of the natives and scenery of New Zealand and South Australia', PIC Artists Drawers, NK2215, Rex Nan Kivell Collection, NLA.

${ }^{8}$ For example, his images appear in Michael King, The Penguin History of New Zealand: Illustrated (Auckland: Penguin, 2007); his images and writing are used throughout Te Ara: The Encyclopaedia of New Zealand, www.teara.govt.nz. Two recent examples of the use of his works as cover illustrations are Damon Ieremia Salesa, Racial Crossings: Race, Intermarriage, and the Victorian British Empire (Oxford: Oxford University Press, 2011); Pei Te Hurinui, King Potatau: An Account of the Life of Potatan Te Wherowhero the First Maori King (Wellington and Auckland: Huia; Polynesian Society, 2010).

${ }^{9}$ G.C. Peterson, "Preface," in Portraits of the New Zealand Maori Painted in 1844, eds. G.C. Petersen and S.M. Mead (Wellington: A. H. and A. W. Reed, 1972), 10.

10 Angas, New Zealanders Illustrated, Preface.
} 
knowing about New Zealand and the colonial encounter that was taking place there: as sites which constructed colonial knowledge.

In the presentation of his works, Angas positioned himself as a reliable and authentic source of information. This thesis divides his positioning into three roles: traveller, artist and natural historian/ethnographer. These roles provide the physical framework from which to interrogate Angas's work. Why did Angas think New Zealand was worth travelling to and how did he travel once he was there? Why did he think it was important to create visual representations of Maori, offering more than 'mere description'? How did the context of his encounter and cultural conventions about aesthetics and science influence the forms of knowledge he was creating?

When Angas arrived in New Zealand he brought with him a particular set of experiences, both personal and cultural that influenced his encounter and his work. He was born on 25 April 1822 in Newcastle-on-Tyne, England, the fourth child and the oldest son of Rosetta French and George Fife Angas. ${ }^{11}$ In 1822 George Fife Angas was helping run the family coach making business, but during Angas's childhood the Angas family became increasingly wealthy and influential. George Fife Angas expanded the business to include shipping and importation, with offices in the West Indies and Spanish America. He also moved into banking. ${ }^{12}$ His imperial connections extended into settlement and colonial interests when, in 1832, he helped found the South Australian Land Company, inspired by Edward Gibbon Wakefield's theories of systematic colonisation. ${ }^{13}$

Also central to the family environment in which Angas was raised were the ethics of Protestantism and of the humanitarian movement. George Fife Angas supported the antislavery movement in Honduras and sponsored missionaries to go the West Indies to prepare the slaves for the 'intelligent appreciation of liberty'. ${ }^{14}$ Following the abolition of slavery in 1833, he participated in the formation of the Aborigines' Protection Society and was a member of its board. The Society believed that part of participating in the expansion of empire was a duty of trusteeship of the 'natives', protecting them from the

\footnotetext{
${ }^{11}$ Fife is sometimes spelt as Fyfe.

${ }^{12}$ Edwin Hodder, George Fife Angas: Father and Founder of South Australia (London: Hodder and Stoughton, 1891), 21.

13 Ibid, 98.

${ }^{14}$ Ibid., $30,33$.
} 
worst effects of European expansion. ${ }^{15}$ George Fife Angas was a diligent member of what Asa Briggs called the 'Age of Improvement', and Boyd Hilton, the 'Age of Atonement'. ${ }^{16}$

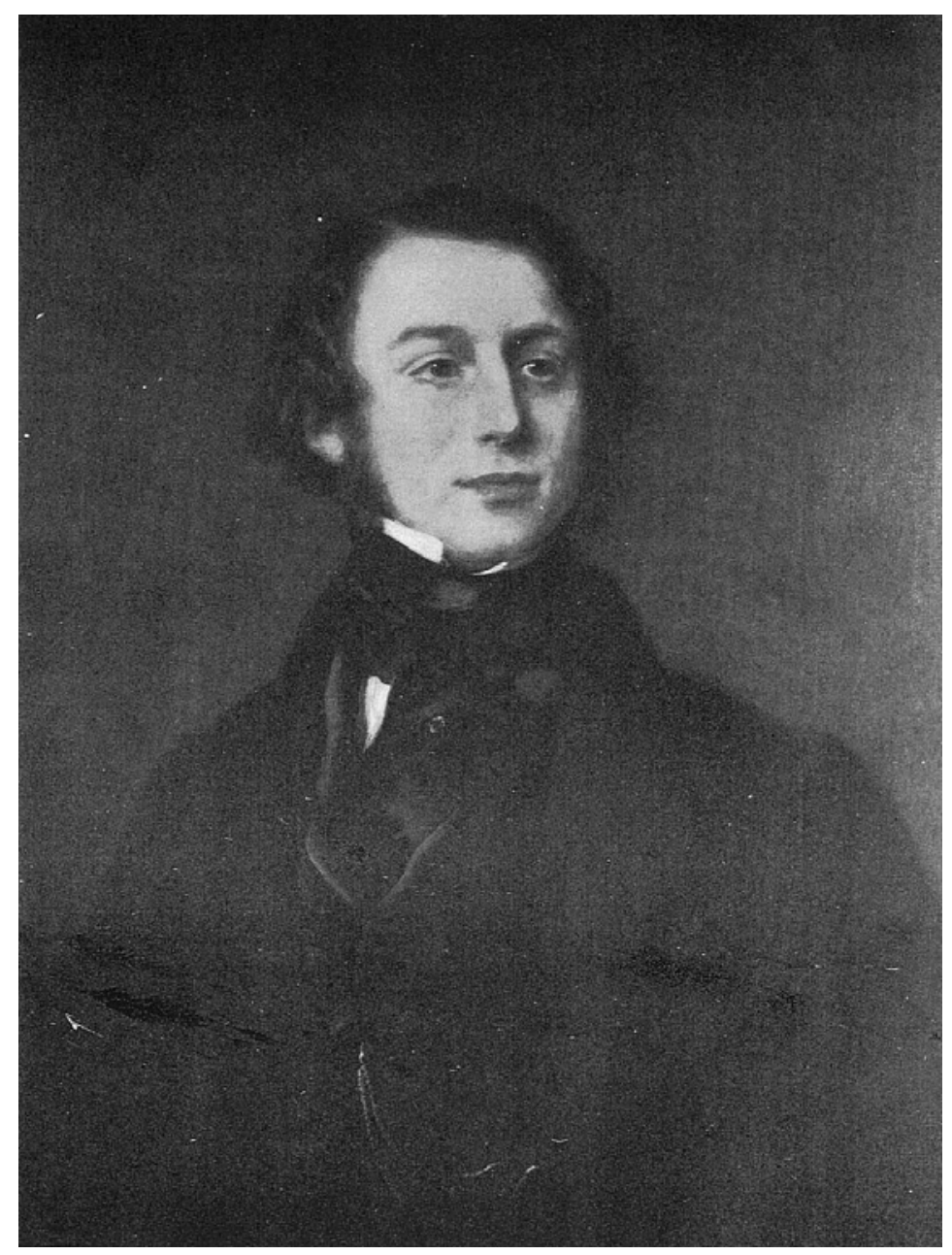

Figure 2: Unknown artist, 'George French Angas,' oil, Catalogue of Important English, European, Australian and New Zealand paintings, Natural History Voyages and Travels, Coloured Book Plates, Prints and Maps, McArthurs and Co., Auckland, 1982.

As the eldest son, Angas was expected to follow his father into the family business. Consequently, upon completion of his schooling, he started work at his father's London counting house near St Mary Axe. After twelve months in the counting house however, Angas rebelled from the religious and business-orientated lifestyle of his father. Angas expressed this rebellion in strong terms:

I broke loose from the trammels that bound me to the artificial world; I was but one amongst the two millions of mighty London, - a mere cipher,

\footnotetext{
15 Report of the Parliamentary Select Committee on Aboriginal Tribes (British Settlements) with Comments by the "Aborigines Protection Society" (London: William Ball and Hatchard \& Son, 1837), 1.

16 Asa Briggs, The Age of Improvement, $1783-1867$ (London and New York: Longman, 1979); Boyd Hilton, The Age of Atonement: The Influence of Evangelicalism on Social and Economic Thought, 1795-1865 (Oxford: Clarendon Press, 1988).
} 
inhabiting but one speck on the wide, free globe. I felt that I was not born to sacrifice every high thought and feeling at the shrine of Mammon: I longed for the natural world; and with a glad and thrilling heart, I shook off, as it were, from my feet the dust of the city, and went forth alone to the uttermost ends of the earth. ${ }^{17}$

Angas achieved his access to the longed for 'natural world' by becoming a travelling artist and natural historian. He also moved away from the religious beliefs of his father. ${ }^{18}$ As a result of these moves, Angas was largely disinherited by his father. His position as a member of the Angas family and his upbringing continued to influence Angas nonetheless. His New Zealand works demonstrated a commitment to humanitarian ideals, though in more secular form.

Circumstances in New Zealand also influenced Angas and his work. He arrived in New Zealand just four years after the signing of the Treaty of Waitangi and the formal creation of New Zealand as a British colony. Formal acquisition had given the British only very limited control. ${ }^{19}$ Disease and the effects of the Musket Wars had reduced the Maori population by about forty per cent from pre-contact numbers but they still vastly outnumbered Pakeha. ${ }^{20}$ It was a 'Maori country' in which British migrants had to settle on the edges, dependent on Maori for food and travel, and in which Maori was the language of communication. ${ }^{21}$ Maori were still 'the New Zealanders'.

In the preface to The New Zealanders, Angas wrote that no country was 'more peculiarly interesting than New Zealand; no race of men more singular than its Aboriginal Inhabitants'. ${ }^{22}$ In the governmental circles of New Zealand, in the Colonial Office in London and in certain vocal sectors of the public, humanitarianism was a very influential ideology. New Zealand had become a testing ground for debates about the negative impact that contact with Europeans was having on indigenous peoples. Nearby Van Diemen's Land provided a worst-case example of what could happen in a colonial

\footnotetext{
${ }^{17}$ George French Angas, The Kafirs Illustrated (London: J. Hogarth, 1849), v.

18 Angas later married an Irish Catholic woman, Alicia Moran, despite his father's fierce dislike of Catholicism, which he described as the "grand Satanic agency employed to create confusion in every Kingdom." Hodder, George Fife Angas,

${ }^{20}$ Ranginui Walker, Ka Whawhai Tonu Matou, Struggle Without End, 2nd ed. (Auckland: Penguin Books, 2004), 80.

${ }^{21}$ Judith Binney, "Kawanatanga and Rangatiratanga: 1840-1860," in The People and the Land: An Illustrated History of New Zealand, 1820-1920: Te Tangata Me Te Whenua, eds. Judith Binney, Judith Bassett, and Erik Olssen (Wellington: Bridget Williams Books, 1993), 79.

22 Angas, New Zealanders Illustrated, Preface.
} 
encounter. ${ }^{23}$ In 1840, just after the signing of the Treaty, the Anglican missionary George Clarke had been appointed New Zealand's first Protector of the Aborigines.

Others amongst the British population in New Zealand were increasingly viewing the Treaty as 'an overly generous reaction to the humanitarian conscience of the treaty period' and demanding access to land and sovereignty. ${ }^{24}$ In 1839 the first New Zealand Company settlers had arrived in Wellington, a group whose 'confidence knew no bounds. ${ }^{25}$ By 1844 the tension between Maori and Pakeha was leading to conflict. Just a year before Angas arrived the Wairau Affray, the first violent conflict over land, had taken place near the New Zealand Company settlement of Nelson leaving twenty six people dead. On 8 July 1844, just weeks before Angas set sail for New Zealand, the young chief Hone Heke, the 'turbulent spokesman' for discontent in the far north, had cut down a flagpole flying the British flag in Kororareka for the first time. ${ }^{26}$

To date, despite the ubiquity of his images, Angas's name is not well known in New Zealand and no in-depth study has been made of his New Zealand work. In Australia he has elicited more interest. In 1980 the Australian art historian John Tregenza wrote a biography, George French Angas: Artist, Traveller and Naturalist 1822-1886. This was produced in conjunction with an exhibition of Angas's work at the Art Gallery of South Australia. Despite being only a short work (twenty-three pages of text) this is still the primary biography of Angas. ${ }^{27}$ The Australian anthropologist Philip Jones has begun work on a biography of Angas and has already written about him within the context of other projects. $^{28}$

Angas's most solid presence in New Zealand is within histories of New Zealand art. It is however a minor presence. Two recent works, for example, Hamish Keith's The Big Picture, 2007 and David Filer's Painting the Frontier: the Art of New Zealand's Pioneers, 2009, include discussions of Angas's works, but, being small parts of larger projects, they are

23 James Heartfield, The Aborigines' Protection Society: Humanitarian Imperialism in Australia, New Zealand, Fiji, Canada, South Africa, and the Congo, 1836-1909 (New York: Columbia University Press, 2011), 71.

${ }^{24}$ Claudia Orange, The Treaty of Waitangi (Wellington: Bridget Williams Books, 1992), 38.

25 Philip Temple, A Sort of Conscience: The Wakeffields (Auckland: Auckland University Press, 2002), 285.

26 Binney, "Kawanatanga and Rangatiratanga," 79.

${ }^{27}$ John Tregenza, George French Angas: Artist, Traveller and Naturalist 1822-1886 (Adelaide: Art Gallery Board of South Australia, 1980).

${ }^{28}$ Philip Jones, "George French Angas: Colonial Artist at Large," in Crossing Cultures: Conflict, Migration and Convergence: The Proceedings of the 32nd International Congress of the History of Art, eds. Jaynie Anderson and Comite international d'histoire de l'art. (Carlton: Miegunyah Press Melbourne University Publishing, 2009), 322-327; Philip Jones, Ochre and Rust: Artefacts and Encounters on Australian Frontiers (Kent Town: Wakefield Press, 2007). 
necessarily brief. ${ }^{29}$ They are however, notable for the consistency of their narrative. They are dismissive of Angas's abilities to accurately depict people: the portraits are 'sentimentalised ${ }^{30}$ and 'misleading confections' that have 'little to do with reality'. ${ }^{31}$ The authors are enthusiastic about the objects Angas painted however, describing them as accurate and as providing a valuable ethnographic record. As Filer wrote, the 'significance of his work in documenting Maori life and custom cannot be denied'. ${ }^{32}$ Two works specifically on portraits, Richard Wolfe's New Zealand Portraits, 2008, and The Power of Portraiture by Erin Griffey, 2008, do not include Angas as a portrait artist of significance. ${ }^{33}$

The exception to this narrative consistency in New Zealand art history is the work of Leonard Bell. His 1992 study Colonial Constructs remains the best analysis of Angas's work. Though his discussion of Angas is also a small part of a larger project, it is a bigger 'small part'. Bell starts to problematise the idea of Angas's works being a good record. Bell's overall argument in this work is that artworks need to be studied as 'constructed' products 'loaded with social and cultural significance'. ${ }^{34}$ In 2000, Susan Mary Campbell's Art History Masters thesis, George French Angas: 'Describing, Prescribing, Inscribing, began to examine the way that Angas's landscape paintings of New Zealand were part of an explicit agenda to construct New Zealand as a European space. ${ }^{35}$

Two other examinations of the work of Angas, one from Australia and one from South Africa, have explored aspects of Angas's work in more depth. In South Africa, the arthistorian Sandra Klopper made a highly critical study of Angas's South African works, which she argues were 'marred by numerous inaccuracies' and produced with a view to 'satisfying the moral strictures and racial preconceptions of the Victorian market for which they are intended. ${ }^{36}$ Rick Hosking, working in the field of English literature and Australian Studies, wrote an article in 2007 which highlighted the privileged position of mobility that Angas's close relationship with colonial administrators allowed him. It

\footnotetext{
${ }^{29}$ David Filer, Painting the Frontier: The Art of New Zealand's Pioneers (Auckland: David Bateman, 2009); Hamish Keith, The Big Picture: a History of New Zealand Art from 1642 (Auckland: Godwit, 2007); See also Gordon H. Brown and Hamish Keith, An Introduction to New Zealand Painting, $1839-1967$ (Auckland: David Bateman in association with Collins, 1969), 17; Gil Docking, Two Hundred Years of New Zealand Painting (Wellington: A.H. \& A.W. Reed, 1971), 26-8; Michael Dunn, A Concise History of New Zealand Painting (Auckland: David Bateman, 1991), 24.

${ }^{30}$ Docking, Two Hundred Years of New Zealand Painting, 26-28.

31 Dunn, $A$ Concise History of New Zealand Painting, 24.

32 Filer, Painting the Frontier, 17.

${ }^{33}$ Richard Wolfe, New Zealand Portraits (Auckland: Viking, 2008). Wolfe mentions Angas only briefly in the introduction; Erin Griffey, The Power of Portraiture: Representing Leadership in New Zealand from 1840 to the Present (Auckland: University of Auckland Business School and David Ling Publishing, 2008).

${ }^{34}$ Bell, Colonial Constructs, 3. See also Bell, The Maori in European Art: a Survey of the Representation of the Maori by European Artists from the Time of Captain Cook to the Present Day (Wellington: A.H. and A.W. Reed, 1980).

${ }^{35}$ Susan Mary Campbell, "George French Angas: 'Describing, Prescribing, Inscribing”" (MA, University of Auckland, 2000).

${ }^{36}$ Sandra Klopper, “A Man of Splendid Appearance: Angas', Utimuni, Nephew of Chaka the Late Zulu King," African Studies 53, no. 2 (1994): 4.
} 
problematised the acts of travel and travel writing and explored the impact these had on Angas's encounter and the work he produced about Australia. ${ }^{37}$

Bell, Klopper and Hosking were writing in the context of a growing academic interest in the nature and processes of empire: new imperial history. It is in this historiographical context that this thesis is situated, though with the benefit of more recent theoretical models. It re-reads Angas's work to 'reconstruct the concerns that generated them, to clarify the logics that organised them'. ${ }^{38}$ This is a study of Angas, a study of New Zealand, and a study of empire: a 'discrete case study', interwoven with broader geographic and ideological frameworks. ${ }^{39}$ It examines the relationship between metropole and colony, which were 'not separate spaces but two sides of a single entity that defined and created each other, that blurred and entwined'. ${ }^{40}$ It also examines transcolonial connections. The New Zealanders was part of an unofficial trilogy of illustrated accounts of British settler colonies. Angas also published South Australia Illustrated in 1846, and The Kafirs Illustrated in 1849 following a trip to South Africa.

The 'discrete case study' is that of Angas's New Zealand encounter and works. The archive on which this study is based is the body of work that Angas produced out of his New Zealand encounter - the published Savage Life and Scenes and the complete collection of The New Zealanders, as well as the watercolours on which the lithographs were based. The particular focus is on the portraits. The timeframe of the study begins in 1844 when Angas arrived in New Zealand, though with reference to earlier events in his life. The thesis then follows Angas's creations into the present to consider how individuals and groups in New Zealand have engaged with Angas's work in various ways.

In recent years New Zealand historians have increasingly called for studies that pay closer attention to the processes of colonisation. In 2002 Peter Gibbons argued that 'historical writings dealing with cultural matters that do not take postcolonial perspectives and problematise the presence of Pakeha run the risk of being considered as parts of the

\footnotetext{
${ }^{37}$ Rick Hosking, “The Privileges of Mobility: George French Angas's Representations of Indigenous People in Savage Life and Scenes and His Debt to 'Learned Friend' William Cawthorne," Studies in Travel Writing 11 (2007): 15-35. 38 Tony Ballantyne, Webs of Empire: Locating New Zealand's Colonial Past (Wellington: Bridget Williams Books, 2012), 17879.

39 Tracey Banivanua-Mar and Penelope Edmonds, "Introduction: Making Space in Settler Colonies," in Making Settler Colonial Space: Perspectives on Race, Place and Identity, eds. Tracey Banivanua Mar and Penelope Edmonds (Basingstoke and New York: Palgrave Macmillan, 2010), 1.

40 Charlotte Macdonald, "Intimacy of the Envelope: Fiction, Commerce, and Empire in the Correspondence of Friends Mary Taylor and Charlotte Bronte, c. 1845-55," in Moving Subjects: Gender, Mobility, and Intimacy in an Age of Global Empire, eds. Tony Ballantyne and Antoinette Burton (Urbana: University of Illinois Press, 2009), 103; The term "transcolonial" comes from Catharine Coleborne, Madness in the Family: Insanity and Institutions in the Australasian Colonial World, 1860-1914 (Basingstoke: Palgrave Macmillan, 2009), 8-9.
} 
colonising process. ${ }^{31}$ There is a challenge in being a descendant of colonists, working within a discipline imported from the colonising culture, and trying to deconstruct the creation of colonial knowledge. Nepia Mahuika argues that European-derived 'cultural and intellectual frameworks' are inadequate for interpreting Maori history and would call me a historian 'from elsewhere'. ${ }^{42}$ My work is potentially a re-enactment of Angas's assertions of 'expert knowledge'. I have sought to avoid this by taking the definition of postcolonial history from Giselle Byrnes's introduction to The New Oxford History, and making this thesis a 'critical engagement with colonisation' which 'critiques and seeks to undermine the structures, ideologies and institutions that gave colonisation meaning, ${ }^{43}$

Angas would not have described himself as 'a creator of colonial knowledge'. He called himself a 'faithful describer' and introduced his works as providing a 'more correct idea'. He did so in an empire that was, as described by Tony Ballantyne, a,

complex agglomeration of overlapping webs, both fragile, prone to crisis where important threads were broken or structural nodes destroyed, yet also dynamic, being constantly remade and reconfigured through concerted thought and effort. ${ }^{44}$

Gathering knowledge and developing particular understandings of what was happening at the nodes of empire was part of the making and configuring of empire. In the mid-1990's a number of historians began to address the role of culture and knowledge in the construction of the British empire. Their works provide a basis from which to start interrogating Angas's work. Nicholas Thomas examined the role of cultural products in the colonisation of the Pacific and the way 'discoveries and trespasses' of empire were 'imagined and energised through signs, metaphors and narratives' ${ }^{45}$ Bernard Cohn and C.A. Bayly, writing about India, focussed respectively on the British empire as an invasion of 'epistemological space' and the role of the 'information order' in imperial administration. ${ }^{46}$ In the foreword to Cohn's book, the anthropologist Nicholas Dirks

\footnotetext{
${ }^{41}$ Peter Gibbons, "Cultural Colonization and National Identity," New Zealand Journal of History 36, no. 1 (April 2002): 15. ${ }^{42}$ Nepia Mahuika, “Closing the Gaps': From Postcolonialism to Kaupapa Maori and Beyond," New Zealand Journal of History 45, no. 1 (2011): 17.

${ }^{43}$ Giselle Byrnes, "Introduction: Reframing New Zealand History," in The New Oxford History of New Zealand, ed. Giselle Byrnes (South Melbourne: Oxford University Press, 2009), 9.

${ }_{44}^{4}$ Tony Ballantyne, Orientalism and Race: Aryanism in the British Empire (Basingstoke: Palgrave Macmillan, 2002), 15.

${ }^{45}$ Nicholas Thomas, Colonialism's Culture: Anthropology, Travel and Government (Cambridge: Polity Press, 1994), 2.

${ }^{46}$ Bernard Cohn, Colonialism and Its Forms of Knowledge: The British in India (Princeton: Princeton University Press, 1996), 4; C. A. Bayly, Empire and Information: Intelligence Gathering and Social Communication in India, 1780-1870 (Cambridge and New York: Cambridge University Press, 1996), 3.
} 
wrote 'colonial knowledge both enabled conquest and was produced by it... knowledge was what colonialism was all about'. ${ }^{47}$

This is a study of the creation of knowledge in the form of a visual record. Central to the way Angas presented the importance of his project in New Zealand was the fact that he was an artist, providing more than 'mere description'. ${ }^{48}$ Bernard Smith's European Vision and the South Pacific, first published in 1960, was an early study of 'the history of art and ideas' but is still valuable to a study of Angas. ${ }^{49}$ This study also uses more recent works that examine the links between art and empire. 'Drawings and paintings', Beth Fowkes Tobin wrote, 'are sites where the tensions and contradictions of colonialist doctrines and practices were negotiated, more or less successfully, on an aesthetic level..$^{50}$ This thesis is also founded on the idea that representations are more interesting for what they tell us about 'the politics of aesthetics and colonial practice' than about the subjects. ${ }^{51}$ The role of art in the colonial process remains understudied in New Zealand. In 2005 Roger Blackley described New Zealand's colonial portraits as a 'vital historical site' and a treasure trove awaiting serious attention. ${ }^{52}$

As studies of people, the knowledge that Angas produced was gendered and embodied. As written by Philippa Levine, the British empire cannot be understood without 'employing a gendered perspective'. ${ }^{53}$ This thesis follows the example of Tony Ballantyne and Antoinette Burton in Bodies in Contact, exploring the 'centrality of body in the articulation of imperial ideologies and in the often fraught dynamics of cross-cultural contact'. ${ }^{54}$ In Angas's work, clothes played a particularly significant role in the ways he understood and represented Maori. This thesis proposes the term 'sartorial colonisation', referring to a process of colonisation through discourses and expectations about the clothing that people wore.

An important feature of Angas's encounter in New Zealand, and therefore of this thesis, is the 'common, mutually comprehensible world' that existed between Maori and Pakeha

${ }^{47}$ Nicholas Dirks, "Foreword," in Cohn, Colonialism and Its Forms of Knowledge, ix.

48 Angas, The New Zealanders Illustrated, Preface.

${ }^{49}$ Bernard Smith, European Vision and the South Pacific, 2nd ed. (Melbourne: Oxford University Press, 1989). First published in 1960 as European Vision in the South Pacific, 1768-1850: a Study in the History of Art and Ideas.

${ }_{50}$ Beth Fowkes Tobin, Picturing Imperial Power: Colonial Subjects in Eighteenth-century British Painting (Durham: Duke University Press, 1999), 1.

51 Philippa Levine, "States of Undress: Nakedness and the Colonial Imagination," Victorian Studies 50, no. 2 (Winter 2008): 189.

${ }^{52}$ Roger Blackley, A Nation's Portraits, Art History Lecture Series 3 (Wellington: School of Art History, Victoria University of Wellington, 2005), 18, 44.

53 Philippa Levine, "Introduction: Why Gender and Empire?," in The Oxford History of the British Empire: Gender and

Empire, ed. Philippa Levine (Oxford: Oxford University Press, 2004), 1.

${ }^{54}$ Ballantyne and Burton, 'Introduction,' in Bodies in Contact, 5. 
in New Zealand. ${ }^{55}$ This thesis uses the term 'middle ground', as described by Richard White in $1991 .^{56}$ There are substantial differences between Angas's encounter in New Zealand and the encounters White was describing in Canada between 1650 and 1815, but the idea that colonial knowledge was not something that was imposed on passive populations of indigenous peoples is central to this study. Angas's experience highlights the role that indigenous people played in new forms of understanding that arose in colonial spaces. He travelled in a world where two cultures met on equal terms and were each of use to the other. Histories such as Vincent O'Malley's Meeting Place, 2012, have also demonstrated a thriving middle ground in New Zealand. ${ }^{57}$

As a humanitarian, Angas in some ways embraced the middle ground but reading his works against the grain reveals an even richer middle ground than he made explicit. As Bronwen Douglas wrote, indigenous agency is 'pervasively, if enigmatically, inscribed in colonial texts, which are steeped in subterranean indigenous presence. ${ }^{58}$ Also important in Angas's work however is the degree to which he denied the middle ground once he had left New Zealand and no longer depended on it. He was from a colonising culture, and no matter how much he professed otherwise, there his work was firmly located.

This study is divided into four chapters. Chapters One, Two and Three each focus on one of the identities that Angas created for himself, using them as a lens to explore the colonial knowledge that he created. Chapter One examines his role as a traveller, Chapter Two focuses on his role as an artist and on the portraits that he created, and Chapter Three concerns Angas as natural historian and ethnographer. Chapter Four brings Angas's work into the present, exploring the ways that they have been engaged with in New Zealand since their creation. This structure was just one possibility amongst many, and will naturally obscure some aspects of Angas' encounter and work that other structures would have highlighted. It diminishes, for example, the degree to which these identities were interlinked. Further studies of Angas and his work will hopefully explore other ways of reading Angas's work.

\footnotetext{
${ }^{55}$ Richard White, The Middle Ground: Indians, Empires, and Republics in the Great Lakes Region, 1650 - 1815 (Cambridge: Cambridge University Press, 1991), ix.

${ }^{56}$ Ibid.

${ }^{57}$ Vincent O'Malley, The Meeting Place: Maori and Pakeha Encounters, $1642-1840$ (Auckland: Auckland University Press, 2012)

${ }^{58}$ Bronwen Douglas, "Science and the Art of Representing 'Savages': Reading 'Race' in Text and Image in South Seas Voyage Literature," History and Anthropology 11, no. 2-3 (1999): 190.
} 
A note on terms: because Angas used the term 'New Zealand', for simplicity and consistency I have chosen to do likewise, rather than 'Aotearoa' or 'Aotearoa/New Zealand'. Also for reasons of simplicity I have decided to call the indigenous people of New Zealand 'Maori' rather than 'New Zealanders', as Angas called them, or 'tangata whenua' as some advocate using now. Despite the fact that Maori was not a widely used term at the time, it is the most widely used and understood term in the present. Angas's use of names for places and people was reasonably accurate. I use the names that Angas did and, if necessary and possible, I provide the present nomenclature in brackets. Angas did not use macrons, so to avoid confusion I have decided not to use them either. 


\section{'Wandering on the Outskirts of Civilisation': The Traveller}

In London, five years after he had been to New Zealand, George French Angas reflected on the times that he had spent travelling. From 'surf-girt islands of the Atlantic' to 'the plains of old Troy, bathed in the glory of Eastern moonlight,' to the 'howling...ice-bound regions of the Antarctic', he had 'stood...amidst', 'roamed amongst' and 'gazed upon', many parts of the world. ${ }^{1}$ Angas was consciously 'a traveller'. Arriving in New Zealand in August 1844, he spent just over four months travelling around the North Island, with a short trip to Queen Charlotte Sound at the top of the South Island. He described his travelling in New Zealand as 'wanderings on the outskirts of civilisation'. ${ }^{2}$ This chapter looks at the ways Angas travelled, exploring the ways he utilised Maori and British networks. It examines his discourses about himself as a traveller and the ways these constructed him as a reliable creator and provider of a 'more correct idea'. The focus of this chapter is primarily on Angas's travel narrative, Savage Life and Scenes.

At the beginning of Savage Life and Scenes, as he was narrating his departure from Britain, Angas included some lines of his poetry:
A thousand miles and more
From our native northern shore,
O'er the broad blue sea
Wanderers are we. ${ }^{3}$

By 'we' he may have been simply referring to his fellow travellers on the Augustus. But it could easily have been a general reference to the many British people who were travelling. The British empire was a place of mobility, defined by the webs that connected distant parts of the world and the ability to move along them. ${ }^{4}$ Angas was joining the many British people who were travelling these webs for many different reasons.

\footnotetext{
${ }^{1}$ George French Angas, The Kafirs Illustrated (London: J. Hogarth, 1849), v-vi.

2 George French Angas, Savage Life and Scenes in Australia and New Zealand: Being an Artist's Impressions of Countries and People at the Antipodes, vol. I (London: Smith, Elder and Co., 1847), vii.

${ }^{3}$ Ibid., I:5.

${ }^{4}$ Tony Ballantyne, Orientalism and Race: Aryanism in the British Empire (Basingstoke: Palgrave Macmillan, 2002), 14-5.
} 
Five months before Angas set sail in April 1843, his younger brother, John Howard Angas, also left for South Australia. John travelled as the new personal agent of his father's affairs in the colony. By 1843, George Fife Angas had significant commercial interests in South Australia. As well as substantial land holdings, he was also a director of the Union Bank of Australia and had helped found the South Australian Banking Company. The colony was in a financial depression and Charles Flaxman, his appointed agent, had been accused of mismanagement. ${ }^{5}$ John was to put things back in order.

It could well have been George French Angas, as the eldest son of the Angas family, who made that particular journey to assist in the establishment of a new settlement colony. But although he initially took the same route as his brother, from London to Adelaide, Angas travelled in very different circumstances and with very different intentions. He had grown up with conceptions of empire beyond those his father was primarily involved in business, religious, and settler-colonial. Later in his life, Angas recounted how he had read the books of famous travellers such as Alexander von Humboldt and Charles Waterton 'by the furtive gleam of a smuggled rushlight' in his boarding school dormitory. ${ }^{6}$ Humboldt and Waterton, both of whom had been to South America, were part of a trend of entertaining but informative narratives of imperial travel. ${ }^{7}$ Angas probably also saw the work of travelling artists, particularly George Catlin's exhibition of Native American portraits, and John Gould's Birds of Australia, published in quarterly parts from $1840{ }^{8}$ At the age of eighteen, after leaving his father's counting house, Angas chose to follow in the footsteps of these traveller-gatherers and spent four months training as a natural history illustrator with the renowned illustrator Benjamin Waterhouse Hawkins.?

\footnotetext{
${ }^{5}$ Charles Bright argues that these accusations were unjust and that Flaxman actually played a significant role in creating George Fife Angas's wealth. See Charles H. Bright, The Confidential Clerk: a Study of Charles Flaxman in South Australia and His Relationship with George Fife Angas (Adelaide: E.H. Bright, 1983).

6 "George French Angas, F.L.S," The Little Journal I, no. 3, Typed Transcript, Mitchell Library (May 1884): 1; Alexander von Humboldt and Aimé Bonpland, Personal Narrative of Travels to the Equinoctial Regions of America, During the Years 17991804, trans. Thomasina Ross, vol. 1 (London: Henry G. Bohn, 1852); Charles Waterton, Wanderings in South America, the North-West of the United States, and the Antilles, in the Years 1812, 1816, 1820 and 1824, ed. L. Harrison Matthews, 1st ed., reprinted (London: Oxford University Press, 1973).

${ }^{7}$ L. Harrison Matthews, "Introduction," in Waterton, Wanderings in South America, the North-West of the United States, and the Antilles, in the Years 1812, 1816, 1820 and 1824, xiv, xv.

8 Philip Jones, "George French Angas: Colonial Artist at Large," in Crossing Cultures: Conflict, Migration and Convergence: The Proceedings of the 32nd International Congress of the History of Art, ed. Jaynie Anderson and Comite international d'histoire de l'art. (Carlton: Miegunyah Press, Melbourne University Publishing, 2009), 322; Bernard Smith, European Vision and the South Pacific, 2nd ed. (Melbourne: Oxford University Press, 1989), 303.

9 John Tregenza, George French Angas: Artist, Traveller and Naturalist 1822-1886 (Adelaide: Art Gallery Board of South Australia, 1980), 7. One of the lithographers with whom Angas worked was W. Hawkins. More research needs to be done as to whether this W. Hawkins was Benjamin Waterhouse Hawkins. Though there is no particular reason to believe Angas did not study with Benjamin Waterhouse Hawkins, as Tregenza wrote, I have also not seen evidence that he did. If W. Hawkins was a different person, could Angas perhaps have studied with him? Pursuing this is unfortunately outside the scope of this study.
} 
British travellers of the empire were actively encouraged by their compatriots to take on the role of gatherers of information. As Mary Louise Pratt noted, the age of the European empires went with 'a European knowledge-building enterprise of unprecedented scale and appeal' with people everywhere 'collecting...measuring, annotating, preserving, making drawings, and trying desperately to get it all home intact'. ${ }^{10}$ In 1825 Angas's father had written, in a prospectus for a society he planned to establish, that imperial merchants were in an excellent position to 'elicit and collect accurate information respecting the state of the different tribes of men'. ${ }^{11}$ Travellers did record and, in the context of an expanding print industry, they published. ${ }^{12}$ By the 1840 s travel literature was in 'full flow. ${ }^{13}$ Travel publication was also notable by this time for the increasing use of images. ${ }^{14}$ In 1842 Angas joined the 'flow' when he published an illustrated account of a journey he had made to Malta and Sicily the previous year, A Ramble in Malta and Sicily in the Autumn of $1841 .^{15}$ When Angas left England for Australia in 1843, he was already planning to publish an illustrated book about South Australia and was enlisting subscribers, an important element in the publication of the sort of high-end book he had in mind. ${ }^{16}$

Malta and Sicily were standard destinations of the 'Grand Tour' undertaken by young British men from privileged backgrounds. When Angas set out for South Australia he was travelling a less well-worn path, but was still within his familial ambit, following the route his brother had taken. Although there was plenty of traffic around the trans-Tasman region in the 1840s, travelling to New Zealand was a more adventurous step for Angas. His inspiration for making the journey across the Tasman was, at least in part, commercial. Before he left Adelaide the South Australian Register reported his plans to illustrate 'the natural scenery of the country, and the habiliments and general contour of the natives. ${ }^{17}$ In the preface to The New Zealanders Angas wrote, 'at the present moment, no country is more peculiarly interesting than New Zealand; no race of men more singular than its Aboriginal Inhabitants'. ${ }^{18}$

${ }^{10}$ Mary Louise Pratt, Imperial Eyes: Travel Writing and Transculturation, 2nd ed. (London and New York: Routledge, 2008), 25.

${ }^{11}$ Edwin Hodder, George Fife Angas: Father and Founder of South Australia (London: Hodder and Stoughton, 1891), 65. The proposed society was the Society for Promoting Christianity and Civilisation through the Medium of Commercial, Scientific, and Professional Agency.

12 Patricia Anderson, The Printed Image and the Transformation of Popular Culture, 1790-1860 (Oxford: Clarendon Press, 1991), 1-2.

13 Peter Hulme and Youngs, "Introduction," in The Cambridge Companion to Travel Writing, ed. Peter Hulme and Tim Youngs (Cambridge: Cambridge University Press, 2002), 7.

14 Anderson, The Printed Image and the Transformation of Popular Culture, 1790-1860, 2-3.

15 George French Angas, A Ramble in Malta and Sicily, in the Autumn of 1841 (London: Smith, Elder and Co., 1842).

${ }_{16}$ Bob Newman to George Fife Angas, 9 October 1844, held by Henry Angas and sighted by Tregenza in 1980, quoted in Tregenza, George French Angas: Artist, Traveller and Naturalist 1822-1886, 8.

${ }_{17}$ Untitled, South Australian Register, 31 July 1844, p.3, col.a. Original italics.

${ }^{18}$ George French Angas, New Zealanders Illustrated (London: Thomas McLean, 1847), Preface. 


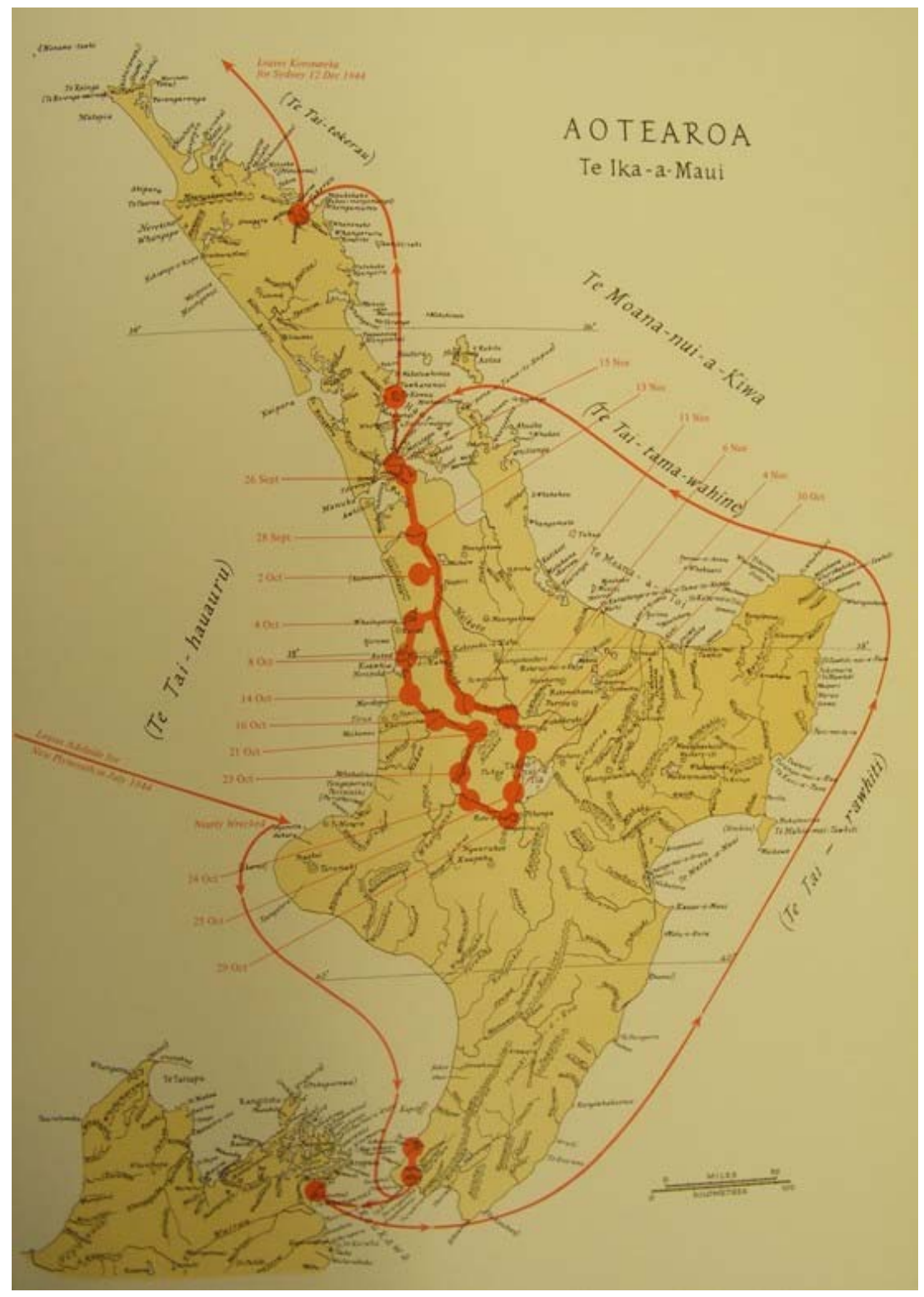

Figure 3: Department of Internal Affairs and G.C. Petersen, 'New Zealand Itinerary, 1844, of George French Angas', printed in George French Angas, Portraits of the New Zealand Maori, with Modern Text by G.C. Petersen and S.M. Mead, 1972. ${ }^{19}$

With his sketchbook and journal ready to record and his insect net and collecting box ready to gather, Angas arrived in New Zealand in August 1844. The schooner he was on arrived at the New Zealand Company settlement of Wellington after being diverted from its intended destination of New Plymouth by a 'gale raging terrifically for twelve hours'. ${ }^{20}$ From Wellington Angas travelled on foot to Porirua and back. He then sailed to Queen Charlotte Sound at the top of the South Island before boarding a boat for Auckland. From there he made the longest leg of his journey, largely on foot down through the

${ }^{19}$ Thank you to the Ministry for Culture and Heritage for granting me permission to include this map.

${ }^{20}$ Angas, Savage Life and Scenes, 1847, I:231. 
Waikato and the Taupo Lake area and back north to Auckland (see Fig. 3). From Auckland he sailed to the Bay of Islands before returning to Australia. ${ }^{21}$

In the introduction to Savage Life and Scenes, Angas suggested that he was 'entitled to the merit of originality' for the fact that he had travelled so widely and so far into 'the interior' in New Zealand. ${ }^{22}$ The extent of Angas's journey was indeed unusual given that he was only in the country for four months but it was certainly not original. There were many other young European and British men travelling extensively in New Zealand at the time that Angas was there. Government officials such as Thomas Spencer Forsaith, working for the office of the Protector of the Aborigines, were travelling on official business. George Selwyn, the new Bishop of New Zealand, was travelling through his diocese. Surveyors and topographical artists such as Charles Heaphy, Samuel Brees and William Fox were travelling in the employment of the New Zealand Company. These travellers were also publishing books based on their travels and experiences. Two examples of these, from 1843 and 1845 respectively, were Travels in New Zealand, with Contributions to the Geography, Botany, and Natural History of That Country by Ernst Dieffenbach, a German scientist working for the New Zealand Company, and Adventure in New Zealand by Edward Jerningham Wakefield, the son of Edward Gibbon Wakefield, founder of the New Zealand Company. ${ }^{23}$

The person whose travels in New Zealand were most similar to those of Angas was Augustus Earle. He had been in New Zealand sixteen years earlier, from October 1827 to May 1828, travelling as a freelance professional artist. Like Angas, his trip to New Zealand was part of a larger journey to various locations across the British empire and sometimes beyond. He spent time in Australia, the United States of America, South America and India. ${ }^{24} \mathrm{He}$ also published an account of his time in New Zealand, A Narrative of a Nine Months' Residence in New Zealand in $1827 . .^{25}$ Unlike those travelling on business for the

\footnotetext{
${ }^{21}$ Sandra Klopper, writing about Angas in South Africa, demonstrated that, although it is now virtually impossible to provide an accurate reconstruction of Angas's journey through South Africa,' his interpretation of the 'outskirts of civilisation' there was in fact somewhat limited, consisting largely of mission stations and the outskirts of Durban. What he said about his travelling in New Zealand should therefore be treated with some caution, but there were significant differences between his time in South Africa and in New Zealand, and there is no reason to believe that what he said about his travelling in New Zealand was not fairly closely aligned with reality. Sandra Klopper, "A Man of Splendid Appearance: Angas' Utimuni, Nephew of Chaka the Late Zulu King," African Studies 53, no. 2 (1994): 5-6.

22 Angas, Savage Life and Scenes, 1847, I:viii.

${ }^{23}$ Ernest Dieffenbach, Travels in New Zealand, with Contributions to the Geography, Botany, and Natural History of That Country, vol. I, II (Capper, 1974); E.J. Wakefield, Adventure in New Zealand, vol. I, II, II vols. (London: William Clowes and Sons, 1845).

${ }^{24}$ Jocelyn Hackforth-Jones, Augustus Earle, Travel Artist: Paintings and Drawings in the Rex Nan Kivell Collection, National Library of Australia (London: Scolar Press, 1980), 1, 4-12.

${ }^{25}$ Augustus Earle, A Narrative of a Nine Months' Residence in New Zealand in 1827 (London: Longman Rees, Orme, Brown, Green \& Longman, 1832).
} 
government, the church or the New Zealand Company, for example, Angas and Earle were not directly affiliated to any particular group or project.

Angas was however indirectly affiliated to a very significant colonial project. Though he chose not to mention it in his published works, his father, George Fife Angas was one of the most influential men in South Australia. Before Angas arrived in South Australia, George Fife sent a copy of $A$ Ramble in Malta and Sicily to George Grey, then Governor of South Australia, and a letter requesting Grey's patronage of his son 'with all the colonial assistance within your power. ${ }^{26}$ It is not known if George Fife Angas assisted Angas's travel any further than this, or if he had anything to do with Angas's journey to New Zealand. It is probable however that the communications with Grey were the full extent of his involvement in his son's travel. George Fife was a strict puritan who disapproved of frivolities such as the theatre and balls. ${ }^{27} \mathrm{He}$ also expected to be obeyed. If God has put me at the head of my family no one has any right to put me at the tail of it', he wrote in a letter to one of his children in $1861 .^{28}$ It is very unlikely that he was impressed by his eldest son's decision to become an artist wandering on the outskirts of civilisation. George Fife Angas was also a notable absence from the subscribers list to New Zealanders Illustrated.

Being the son of George Fife Angas and having the patronage of the Governor of South Australia was no small advantage for a traveller in New Zealand. It gave Angas access to colonial networks. ${ }^{29}$ One of the most significant colonial connections Angas made in New Zealand was meeting Thomas Spencer Forsaith who was working for the office of Protector of the Aborigines. Angas travelled with Forsaith for about three weeks from Auckland to Kawhia Harbour in Waikato. Angas also stayed with 'my friend Dr Sinclair, the colonial secretary' in Auckland..$^{30}$

\footnotetext{
${ }^{26}$ George Fife Angas to George Grey, 20 February 1843 and 31 May 1843, PRG 174/22/4 and 9, SLSA, quoted in Jones, "George French Angas: Colonial Artist at Large," 323. The Auckland Library's copy of The New Zealanders Illustrated was a gift to Sir George Grey from the Angas family. A portrait of the George Fife Angas is pasted inside the cover and it is signed "Yours very affectionately, George Fife Angas." Angas was also assisted in various ways by his father at later points in his life. A timely donation from George Fife Angas helped secure Angas his job at the Australian Museum in 1852. He later facilitated Angas's election to various official positions in Angaston including Returning Officer in 1860, and Chairman of the District Council in 1861. However Angas never seems to have had much in the way of financial assistance from his father. When George Fife Angas died, Angas was bequeathed an annuity of $f, 1000$ a year for the rest of his life. He was a very wealthy man, and $f_{1000}$ per annum was a small sum compared to what John Howard received.

${ }^{27}$ Hodder, George Fife Angas, 420.

${ }^{28}$ George Fife Angas to unknown offspring, 21 March 1861, Adelaide, quoted in ibid., 422-3.

${ }^{29}$ Rick Hosking, "The Privileges of Mobility: George French Angas's Representations of Indigenous People in Savage Life and Scenes and His Debt to 'Learned Friend' William Cawthorne," Studies in Travel Writing 11 (2007): 19; Jones, "George French Angas: Colonial Artist at Large."

${ }^{30}$ Angas, Savage Life and Scenes, 1847, I:294.
} 
These contacts also allowed Angas to utilise what Zoe Laidlaw called 'networks of interest'. ${ }^{31}$ He met with other natural historians such as '[m]y friend, Mr Percy Earl, the enterprising naturalist'. Earl was, Angas wrote, 'happily for me, at Wellington during the period of my visit; and we spent many pleasant hours together, talking over the natural history of New Zealand'. ${ }^{32}$ Angas also described Ernst Dieffenbach as his friend. ${ }^{33}$ Dieffenbach had gone back to Britain in 1841 so Angas must have met him in England, either before or after his journey to New Zealand. Another network which facilitated Angas's travel was that of missionaries. ${ }^{34}$ Angas was not alone in using these networks they were how people travelled at the margins of empire. Another portrait artist, Joseph Merrett, met Dieffenbach in 1841 and travelled with him to Taupo. ${ }^{35}$

In Australia one of the people Angas met through networks of interest was William Cawthorne, a young man developing a reputation as a collector of aboriginal artefacts and who had contacts in aboriginal communities. ${ }^{36}$ Cawthorne's diary entry described his meeting with Angas. 'At 5', he wrote, 'Mother and me had tea and who, in the name of fortune, should come upon us in this precious plight but Mr G.F. Angas!!!' When Angas requested Cawthorne's assistance,

[m]ost decidedly, I answered, and if I would just give him all the names. Certainly. And if I would be so kind to come up to his house in the evening. Of course. And if I could bring this, that, and the other with me. Oh, he would be so very very much obliged to me etc etc. To all these 'ifs' and 'ands' I readily acceded and after each he gave a beseeching smile that would have captivated a 'hyena', let alone me. ${ }^{37}$

Charming enough to captivate a hyena, and backed up by impressive connections, Angas was clearly an engaging person and something of a celebrity.

As Cawthorne's diary entry suggests, Angas was also reliant on the people he met through these networks for information. Having lived in New Zealand longer and being more familiar with the people and the land, they provided much of the detail that went into

31 Zoë Laidlaw, Colonial Connections, 1815-45: Patronage, the Information Revolution and Colonial Government (Manchester and New York: Manchester University Press, 2005), 16.

32 Angas, Savage Life and Scenes, 1847, I:243.

33 Ibid., I:229.

${ }^{34}$ For example, George French Angas, Savage Life and Scenes in Australia and New Zealand: Being an Artist's Impressions of Countries and People at the Antipodes, vol. II (London: Smith, Elder and Co., 1847), 36; Angas, Savage Life and Scenes, 1847, I:275.

35 Roger Blackley, “The Portraits of Joseph Merrett,” Art New Zealand Number 56 (Spring 1990): 85.

36 Tregenza, Jean, 'William Anderson Cawthorne,' Design and Art Australia Online, www.daao.org.au/bio/williamanderson-cawthorne/biography

${ }^{37}$ William Cawthorne, Journal entry, 2 February 1844, quoted in Philip Jones, Ocbre and Rust: Artefacts and Encounters on

Australian Frontiers (Kent Town: Wakefield Press, 2007), 84. 
Angas's published work. Angas records, for example, that Dieffenbach had been climbing and measuring Mt Taranaki/Egmont and that Mr Earl had been travelling in the 'middle island,' where 'he had obtained some recently fossilised bones of the gigantic moa, ${ }^{38}$

People seemed happy to help Angas. Russell Viljoen, in his study of Angas's time in South Africa noted that the missionaries he met there were willing to act as informants, translators and liaison agents in exchange for positive commentary about their work'. ${ }^{39}$ In New Zealand the British population was divided about how the new colony should proceed. The New Zealand Company, missionaries, colonial officials, and traders all had different views. It was very likely that, like the missionaries in South Africa, the people who helped Angas understood that he was crafting a view of New Zealand for a public audience, and that he therefore had the power to create knowledge that favoured their particular views.

In some instances, the information that Angas used was not provided but taken, or was provided but was not credited. Cawthorne received no mention in Angas's works and the Daily Southern Cross described an unknown 'gentleman' in Auckland as providing Angas with information about Maori that went into The New Zealanders. ${ }^{40}$ Five of the images in The New Zealanders were copies of works by Joseph Merrett. ${ }^{41}$ Using uncredited information from other people or sources was not an unusual practice for the time but Angas does seem to have been particularly insensitive about it, causing significant irritation amongst some of those who he failed to recognise. ${ }^{42}$

Angas was primarily in New Zealand to document Maori. Therefore, the most significant aspect of these colonial connections was that they enabled him to connect with, and move into Maori networks. When Angas joined him, Forsaith was travelling to discuss land issues with Maori leaders. Because of the importance of these issues, Forsaith's arrival in a location would attract large numbers of Maori leaders from whom Angas could then obtain portraits. ${ }^{43}$ Missionaries had a comparatively long history of interaction with Maori leaders and communities so were also crucial cross-cultural facilitators. Angas records, for example, getting considerable help from Reverend Whiteley of the Kawhia Harbour

\footnotetext{
38 Angas, Savage Life and Scenes, 1847, I:243.

39 Russel Viljoen, “'Sketching the Khoikhoi': George French Angas and His Depiction of the Genedendal Khoikhoi

Characters at the Cape of Good Hope, c. 1847," South African Journal of Art History 22, no. 2 (2007): 279.

40 'Forthcoming Publication,' Daily Southern Cross, 30 November 1844, p.2, col.c.

${ }^{41}$ Blackley, "The Portraits of Joseph Merrett,” 82, 111 f.n. 3. These were Plates II, XXXVI, XLV, LII, LIII.

42 Jones, Ochre and Rust, 84-86; Hosking, "The Privileges of Mobility," 20, 29; "Mr George French Angas's Exhibition of Water Colour Paintings', South Australian Register, 21 June 1845, p.2, col.f - p.3, col.b. This article mentions Algernon Wilson, a "nature amateur" who supplied the images and written descriptions for some of the plates in South Australia Illustrated, but was uncredited.

${ }^{43}$ Angas, Savage Life and Scenes, 1847, II:70.
} 
mission station. He wrote, 'through the kindness of that gentleman I was enabled to procure likenesses of many who, under ordinary circumstances, would have been difficult of approach'. ${ }^{4}$

The British communities that Angas was interacting with in New Zealand represented a very small part of the population. In 1844, New Zealand was a Maori country. ${ }^{45}$ When Angas narrated his arrival in Wellington, even though it was a New Zealand Company settlement, Maori had a clear presence. 'On each side of the town is a native "pah", or village: that on the right, facing the water, is called Te Aro...the one on the left is known as Pipitea'. ${ }^{46}$ In the centre of town was 'a small patch of land, reserved by the chief, E Tako [Wi Tako, a Te Ati Awa leader], where he has erected a substantial weather-board house for himself and his family' ${ }^{47}$

Angas quickly connected with Maori networks, moving into New Zealand's 'middle ground'. ${ }^{48}$ He described visiting Pipitea pa on the morning of his arrival where he met Nga Tata (Ngatata-i-te-rangi), 'the chief of Pipitea and Kumototo' and father of E Tako, the chief of Port Nicholson. ${ }^{49}$ There he met a young woman he called 'Kahoki, a niece of Rauparaha and daughter of the chief of the Rotorua Lakes' ${ }^{50}$ This woman was probably Rakapa Kahoki, the daughter of Rangi Topeora, a very powerful woman of Ngati Toa who signed the Treaty, had herself baptised 'Queen Victoria', and was known as the 'Queen of the South'. ${ }^{51}$ Kahoki was visiting Pipitea Pa, and Angas wrote, 'so delighted was she with the painter's art, that she offered to accompany me with her attendants on a sketching tour to the lakes at Roturua, promising me her protection and influence amongst her friends to obtain all the portraits I might desire. ${ }^{52}$ In Wellington, Angas also met Te Rauparaha, chief of Ngati Toa and one of the most influential people in New Zealand in 1844. Te Rauparaha's nephew, 'Tuarau or Kopai' became Angas's first guide and travelling companion when they travelled to Porirua a few days later. ${ }^{53}$

\footnotetext{
${ }^{44}$ Ibid., II:69. See also Jane Lydon, Eye Contact: Photographing Indigenous Australians (Durham: Duke University Press, 2005), xiii. In this work Lydon wrote about the role of missionaries in giving other Europeans access to Aboriginal communities and leaders in Australia. She described mission stations as zoo-like in the way that this occurred. 45 Claudia Orange, The Treaty of Waitangi (Wellington: Bridget Williams Books, 1992), 31.

46 Angas, Savage Life and Scenes, 1847, I:232.

47 Ibid., I:233.

48 Richard White, The Middle Ground: Indians, Empires, and Republics in the Great Lakes Region, 1650 - 1815 (Cambridge: Cambridge University Press, 1991).

${ }^{49}$ Angas, Savage Life and Scenes, 1847, I:235.

${ }^{50}$ Ibid., I:238.

51 Teremoana Sparks and W.H. Oliver. 'Topeora, Rangi Kuini Wikitoria - Biography', Dictionary of New Zealand Biography, Te Ara: the Encyclopaedia of New Zealand, www.teara.govt.nz/en/biographies/1t103/topeora-rangi-te-kuini

52 Angas, Savage Life and Scenes, 1847, I:239.

${ }^{53}$ Ibid., I:245.
} 
One of the Maori leaders Angas met and drew was Te Wherowhero, described by Angas as the 'principal chief of all Waikato'. In the 1850s he would become the first Maori King. Angas's description of his encounter with Te Wherowhero provides an example of the way that Angas travelled in New Zealand. In Savage Life and Scenes Angas recorded meeting Te Wherowhero at Whatawhata on the 4 October 1844. Angas and Forsaith had journeyed some distance to meet him. When they arrived Te Wherowhero was 'superintending his people at their work' planting kumara and building a house. ${ }^{54}$ 'The only effect our arrival had upon this veteran warrior,' Angas wrote, 'was a smile of welcome: without in any way moving his position, he shook hands with us most heartily' Angas described Forsaith as having important business with this chief on matters connected with government' and Forsaith and Te Wherowhero quickly became engaged in 'deep conversation and argument'. ${ }^{55}$ To Te Wherowhero, Angas's presence was incidental to this more important meeting with the representative of the colonial government.

However, when it started raining, Te Wherowhero 'most politely ordered some of his people to erect a temporary shed' over Angas. ${ }^{56}$ Angas also received a letter of introduction from Te Wherowhero to Te Heuheu, chief of Ngati Tuwharetoa. In translation it read,

Whata Whata, Oct. 4th, 1844.

Friend Heuheu,--Health to you! Let your hospitality be very great to this stranger who is going to see you. Your name has carried him away. He is a writer of images; he belongs to me--to Potatau. Be kind to this European. Take heed you do not despise my book. He is a strange foreigner from England.

By me, your friend,

POTATAU.

Te Heuheu. ${ }^{57}$

Angas did not command Te Wherowhero's full attention, but he was still someone worth assisting.

With only Angas's version of the events recorded, we cannot know the motivations of the Maori individuals and groups who helped Angas. In his study of the display of Maori

\footnotetext{
54 Angas, New Zealanders Illustrated, Plate XLIV.

55 Angas, Savage Life and Scenes, 1847, II:50.

${ }^{56}$ Ibid., II:51.

${ }^{57}$ Ibid., II:52.
} 
culture in New Zealand, Conal McCarthy argued that Maori used European cultures of display to actively 'self-position' in the contact zone. ${ }^{58}$ Display, he noted, 'demonstrated mana'. ${ }^{59}$ This may, at least in part, explain the willing assistance Angas received. In Savage Life and Scenes, Angas described his reception by Maori as a 'stranger from the Queen of England'. '[M]y coming from Europe,' he wrote, 'for the purpose of representing their chiefs and their country was considered by them as a compliment. ${ }^{60}$ In Waingaroa (Raglan) at Wallis' missionary station Angas wrote, 'during the entire day the court-yard has been crowded with natives, all anxious to have their likenesses taken, that they may go to England with those of the Rangatiras: upwards of thirty found their way in the room where I was engaged in painting. ${ }^{61}$

Angas could not have travelled without Maori assistance. As well as enablers (or sometimes preventers) of his travel, they were also luggage bearers and guides. Leaving Auckland and heading towards the Waikato, Angas and Forsaith were accompanied by,

five Maori lads, who carried our baggage; this consisted of bundles of clothing, sketching apparatus, collecting boxes, a small tent, and a basket of provisions: which they severally carried in their pikau or knapsacks, strapped over their shoulders with the leaves of flax. ${ }^{62}$

From Raglan when Angas and Forsaith parted ways, Angas was guided through the Taupo region and back to Auckland by 'E Pera, who was a Nga Pui from the Bay of Islands, and E Rihia, a mission lad of Waipa, belonging to the Ngati Apakura tribe'. ${ }^{63}$ Many times these guides got him out of difficult situations. In one instance, demonstrating the mixed power relations between guide and guided and the fragile position colonial settings could put the European body in, Angas and Forsaith had to be carried over a river 'with our feet resting on one fellow's shoulders and our backs on the head of another'. ${ }^{64}$

Though he was reliant on Maori for his travelling, Angas did not always respect their travelling rules. In some instances he stepped outside the middle ground, using deception to invade areas which were sacred. He was happy to describe this to his audience. 'Day

\footnotetext{
58 Phillips, 2005, p. 117, quoted in Conal McCarthy, Exbibiting Māori: a History of Colonial Cultures of Display (Oxford and New York: Berg, 2007), 32.

59 Ibid., 27. Original italics.

${ }^{60}$ Angas, Savage Life and Scenes, 1847, II:2.

${ }^{61}$ Ibid., II:58 Original italics.

62 Ibid., II:3.

${ }^{63}$ Ibid., II:74.

${ }^{64}$ Ibid., II:11.
} 
after day,' he wrote, 'have I spent exploring ruined and tapued pahs, frequently by stealth'. ${ }^{65}$ In one instance he was helped by another European. '[W]ith the assistance of Newman I eluded the suspicions of our natives, and rambled all day amongst the decaying memorials of the past, making drawings' ${ }^{66}$

The middle ground was very important in the creation of Angas's work but there was a key difference between the middle ground in Angas's encounter and that described by White when he coined the term. Though Angas was dependant on it to travel and obtain his images, he was able to reject the middle ground once he was out of New Zealand and no longer needed it. In his narratives he distanced himself from the middle ground and located himself firmly within British culture. The primary focus of his published works was 'home. ${ }^{67}$ Savage Life and Scenes rarely lost sight of the land from which Angas had come. Upon his arrival in Adelaide just after the long sea journey from Britain, he composed the lines:

They left their native land, and far away

Across the waters sought a world unknown;

Yet well they knew that they in vain might stray

In search of one more lovely than their own. ${ }^{68}$

In New Zealand, arriving at Waingaroa harbour (Whaingaroa Harbour, Raglan) after having come overland from Auckland, he saw the sea and wrote, 'the sudden sight of that vast and watery barrier of human hopes and ties, made me feel how truly I was a wanderer in a strange land - a voluntary exile from all I love'. 'Beyond that ocean lay all I cared for on earth'. ${ }^{69}$

Angas presented his travel to his audience in a way that established his legitimacy as an observer and the reliability of his 'correct idea'. One way he established this was to emphasise what kind of traveller he was not. At the beginning of Volume II of Savage Life and Scenes, as he departed from Auckland for the most remote areas he would visit in the Waikato and Taupo, Angas wrote '[m]y mission amongst [Maori] was one of peace: I did

65 Angas, Savage Life and Scenes, 1847, I:267. Original italics.

66 Angas, Savage Life and Scenes, 1847, II:126.

${ }^{67}$ Steve Clark, "Introduction," in Travel Writing and Empire: Postcolonial Theory in Transit, ed. Steve Clark (London and New York: Zed Books, 1999), 1.

68 Angas, Savage Life and Scenes, 1847, I:39.

${ }^{69}$ Angas, Savage Life and Scenes, 1847, II:56. 
not covet their land'. ${ }^{70}$ This statement epitomises what Pratt calls 'anti-conquest' travel: a strategy of representation 'whereby European bourgeois subjects seek to secure their innocence in the same moment as they assert European hegemony. ${ }^{71}$

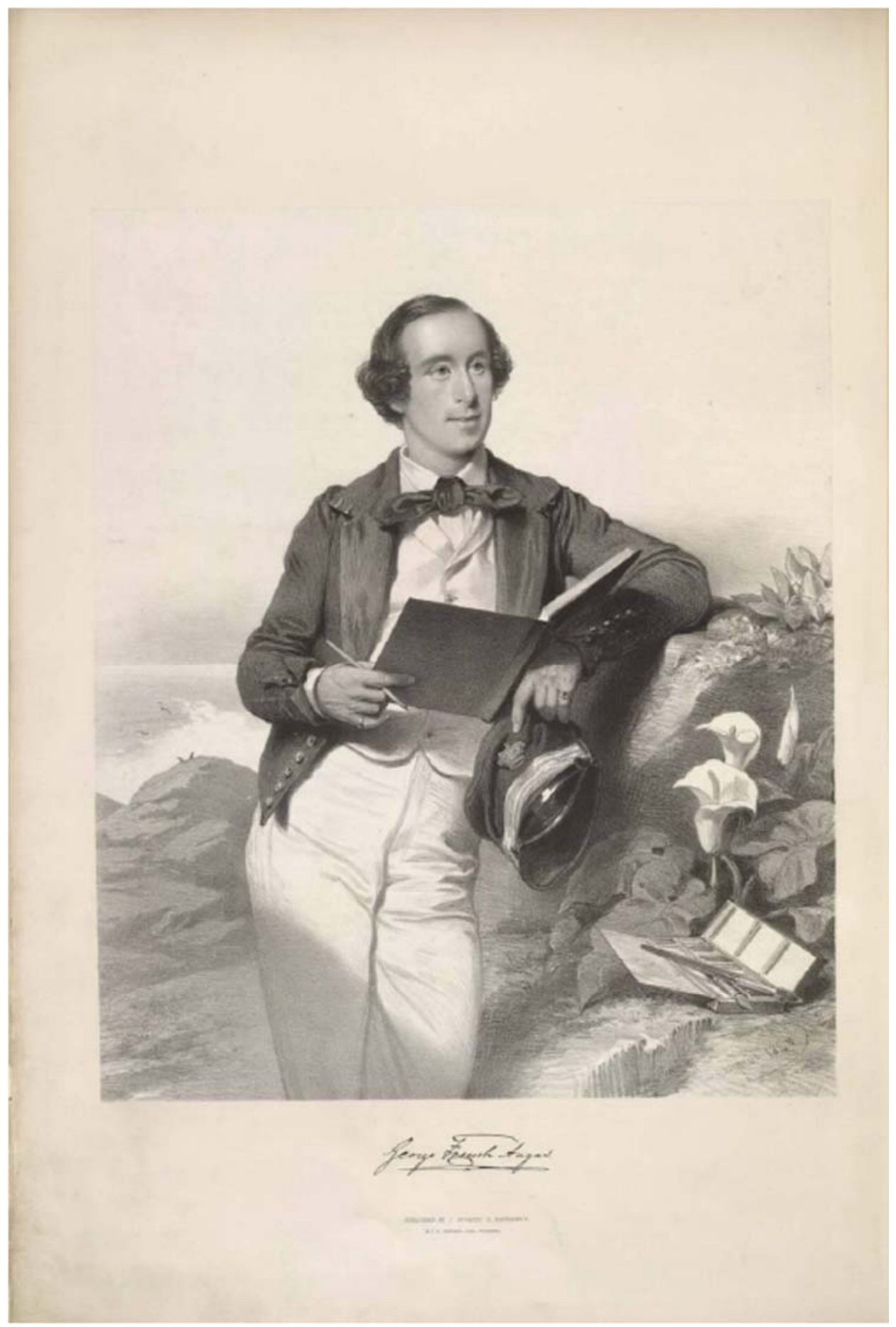

Figure 4: Charles Baugniet, 'George French Angas', lithograph, from George French Angas, The Kafirs Illustrated, London, 1849, frontispiece.

\footnotetext{
70 Ibid., II:2.

${ }^{71}$ Pratt, Imperial Eyes, 9.
} 
The physical form that Angas's body took and the way that it moved were central to this representation. In Savage Life and Scenes he described his movement as 'wandering' and 'rambling. ${ }^{72} \mathrm{He}$ also emphasised the spontaneity of his journey to New Zealand. 'One evening,' he wrote, 'whilst sitting in my verandah at Adelaide, I took it into my head to visit New Zealand'. ${ }^{73}$ He did not present a physical image of himself in his New Zealand publications, but he did two years later, in 1849, in Kafirs Illustrated. ${ }^{74}$ The lithograph from a watercolour by Charles Baugniet, a leading society portraitist in Britain, showed Angas leaning casually on a rock with his hat removed and his clothes a little rumpled, mildly contemplating the middle distance (see Fig. 4).

In many ways Savage Life and Scenes was the narrative of a Romantic traveller. He described himself as having rejected the world of commerce and choosing to travel because of 'an ardent admiration of the grandeur and loveliness of Nature in her wildest aspect'. ${ }^{75}$ The work contained long and ecstatic passages about the grandeur of nature. On board the Augustus, shortly after leaving England, for example, Angas described a sunset:

Streams of molten gold have streaked half the horizon with their intense brilliancy... There poured such a flood of living crimson around, that every blue wave changed from the hue of the sapphire to that of the amethyst, and the whole arch of heaven was full of purple light... then came the calm, grey night, and the awful stillness of the ocean, as it slept beneath a shower of moonbeams. Surely if there were sea-nymphs, or green-haired mermaidens, they would have chosen just such a glorious night for their syren-singing. ${ }^{76}$

In his New Zealand narrative, one of Angas's first comments was in response to viewing a sunrise over Mt Taranaki as his ship approached land:

The scene I now looked upon was beyond description magnificent...behind the dark slope of the mountain...the vault of the heavens was embroidered, as it were, with fantastic patterns of richly wrought cloud, woven into the most delicate tracery by the fresh east wind. ${ }^{77}$

While visiting some limestone caves in the Waikato, Angas quoted from 'Kubla Khan', a poem by Samuel Taylor Coleridge, one of the most famous Romantic poets. ${ }^{78}$ Even more

\footnotetext{
72 Angas, Savage Life and Scenes, 1847, I:vii; Angas, Savage Life and Scenes, 1847, II:166.

73 Angas, Savage Life and Scenes, 1847, I:224.

${ }^{74}$ Angas, The Kafirs Illustrated, frontispiece.

${ }^{75}$ Angas, Savage Life and Scenes, 1847, I:vii.

${ }^{76}$ Ibid., I:3-4.

77 Ibid., I:229.

${ }^{78}$ Angas, Savage Life and Scenes, 1847, II:93.
} 
pronounced in his work was the trope of the 'picturesque'. Even as he described the most arduous parts of his journeys in New Zealand he would stop to describe how picturesque a scene was. ${ }^{79}$

Alongside the presentation of himself as a casual and spontaneous traveller was another version of his travelling: he was also a careful and thorough traveller. This was Angas the natural historian gathering facts rather than Angas the artist. Though the two versions were discrepant in some ways, they both served to further Angas's claim of being a reliable conveyor of information about New Zealand. Nor did Angas himself seem to have seen any discrepancy. In the preface to Savage Life and Scenes, he wrote 'I invariably noted down on the instant whatever facts and impressions seemed worth recording. ${ }^{80}$ 'Facts' and 'impressions' could sit happily side by side without contradiction. Angas was not unusual in having both Romantic and scientific modes within one body of work. These were two of the most influential ideological currents of the nineteenth century and evolved alongside each other. ${ }^{81}$ They were 'the two eternally clashing and complementary languages of bourgeois subjectivity. ${ }^{, 82}$

In the portrait of Angas, though he was casual, he also had his sketchbook open, a pencil in his hand, and his box of paints at his side: he was prepared and ready to record. $\mathrm{He}$ presented his published works as made 'on the spot', unmediated. In the introduction to Savage Life and Scenes, he wrote that his preparation for publication involved simply 'arranging in a readable form the rough notes that I made at the moment'. ${ }^{83}$ The occasional journal-style dated entry served to remind the reader that this was, at least in part, unprocessed, original material.

In this more active mode of travelling Angas described himself as 'penetrating' space. ${ }^{84}$ This sort of language of masculinised domination challenged his narrative of anticonquest. The majority of the time though, being an active traveller lent credibility to his anti-conquest narrative. Angas emphasised the lengths to which he had gone to obtain his information. When he 'visited both Islands of New Zealand, and spent a considerable period in travelling round their coasts...seeking out nearly every tribe of natives, and living amongst them for some time, in the remote and almost unknown parts of the

${ }^{79}$ See for example Angas, Savage Life and Scenes, 1847, I:245.

${ }^{80}$ Ibid., I:vii.

${ }^{81}$ Smith, European Vision and the South Pacific, 1.

82 Pratt, Imperial Eyes, 38.

83 Angas, Savage Life and Scenes, 1847, I:viii.

${ }^{84}$ Ibid.; Angas, New Zealanders Illustrated, Preface. 
country', ${ }^{85}$ these were the actions of a dedicated traveller. He wrote of travelling by foot on difficult paths, 'scarcely passable,' and 'constantly obstructed'. ${ }^{86} \mathrm{He}$ had to contend with 'frequent precipices, swamps, and rivers' which 'offer obstacles' to progress 'that require some ingenuity to overcome. ${ }^{87}$ Soon after leaving the pah of Te Heuheu Tukino II at Te Rapa, Angas wrote:

We had awful travelling this day: fearful ascents and descents of steep precipices of pumice and lava, and narrow slippery paths, frequently on the verge of a cliff overhanging some dark and troubled stream. Dense mists were hanging over thousands of broken hills, that looked most truly desolate; and volcanic rocks, high and jagged, rose in abrupt masses... ${ }^{88}$

Angas also presented his encounter in New Zealand as dangerous. Near the beginning of the longest part of his journey to the districts of Taupo and Waikato, the 'interior,' he described meeting an 'old captain' who warned Angas and Forsaith of the 'depredations of the natives' and who kept his gun cocked in case of trouble. 'The very people,' Angas concluded, 'amongst the least civilised of whom I was going alone and unarmed, were represented to us as a race of banditti. ${ }^{89}$ The journey that Angas made in New Zealand was, to a degree, dangerous. The nature of his travelling put him at physical risk. After leaving Te Rapa, he and his guides were travelling through 'soaking rain' and wind. Having spent a couple of days being 'cold and wretched' Angas fell ill with 'violent influenza' at a place he calls Tutukamauna. ${ }^{90}$ In 1848, while travelling in South Africa, he became severely ill, spent time in a mission hospital, and never entirely recovered his full health.

The title of the book, Savage Life and Scenes, indicated not just the life Angas was observing, but also the life he was living. 'Living amongst' and sometimes accompanied 'only by natives, ${ }^{91}$ he presented himself as sometimes having gone further than 'the outskirts of civilisation'. For the sake of his audience he had crossed the boundary from the civilised world to the savage world, becoming himself, temporarily, savage. A vital moment in his narrative, however, was when he emerged from the wilderness and returned 'home'. Unlike those Europeans who became 'Pakeha-Maori', such as 'Newman' and 'Lewis' who Angas encountered, or one of the most famous, F.E. Maning, Angas's crossing of the

85 Angas, New Zealanders Illustrated, Preface.

86 Angas, Savage Life and Scenes, 1847, I:245.

${ }^{87}$ Angas, Savage Life and Scenes, 1847, II:1.

88 Ibid., II:137.

${ }^{89}$ Ibid., II:6.

${ }^{90}$ Ibid., II:132, 134.

${ }^{91}$ Ibid., II:2; Angas, New Zealanders Illustrated, Preface. 
cultural boundaries, and his becoming savage, was only temporary. He emerged from the 'interior' and 'once more exchanged savage for civilised life' and was welcomed by the (presumably British) people of Auckland. ${ }^{92}$

Angas left New Zealand in December 1844 on a ship sailing from the Bay of Islands to Sydney, New South Wales. He had with him a written journal of his experiences and an extensive collection of sketches and watercolours of Maori and Maori culture. Also with him was Hemi Pomare/Pomara, a Maori boy about whom very little is known. He went with Angas to Australia and then to London where, in 'costume', he was part of the Egyptian Hall exhibition. Angas spent some time in New South Wales then made his way back to Adelaide. Later in 1845 he began his homeward voyage, travelling via Rio de Janeiro. He arrived back in London on 23 February 1846.

After Angas's departure from New Zealand in 1844, the process of the country's transition to a settler colony continued. Concepts of land ownership and sovereignty were increasingly contested and the middle ground receded. In March 1845, Hone Heke cut down the flagpole in Kororareka for the fourth time. The township was attacked as a diversion, and the HMS Hazard opened fire on Heke and his followers, beginning the Northern Wars (1845-46). ${ }^{93}$ From 1860 and the invasion of Waitara after the establishment of Te Kingitanga (the King Movement), as Judith Binney wrote, Maori independence was more 'systematically crushed'. ${ }^{94}$ Across the empire, relations between the British and peoples they were colonising hardened. As the Pakeha population increased and governmental structures became more established, a European New Zealand identity was gradually formulated. Pakeha became 'the New Zealanders'. In 1886 when Angas died, little of the New Zealand he had known in 1844 remained.

Angas continued to travel throughout his life. He travelled to South Africa in 1848 and in the resulting publication, The Kafirs Illustrated, he made his most comprehensive statements about his identity and role as a traveller:

92 Angas, Savage Life and Scenes, 1847, II:161.

93 Judith Binney, "Kawanatanga and Rangatiratanga: 1840-1860," in The People and the Land: An Illustrated History of New Zealand, 1820-1920: Te Tangata Me Te Whenua, ed. Judith Binney, Judith Bassett, and Erik Olssen (Wellington: Bridget Williams Books, 1993), 81.

${ }^{94}$ Ibid., 97. 
Seven years of travel, and I am not satisfied. I look upon the world's chart, and feel my own insignificance when I see how few and how tiny are the spots that I have visited when compared with the many unknown realms that are traced upon its vast surface. ${ }^{95}$

After his journey to South Africa, ill health and raising a family prevented him from doing any further extensive travel. He was appointed as the naturalist to the Turko-Persian Boundary Commission, but became severely ill and had to return to England. ${ }^{96} \mathrm{He}$ did continue to travel throughout the rest of his life, but in different ways. He moved with his wife Alicia Moran to Australia for a number of years. He travelled to Southern Europe and the West Indies for health reasons, and to Dominica on a 'specimen collecting trip' two years before his death in $1886 .{ }^{97}$

Angas's presentation of himself as wandering on the outskirts of civilisation, innocently untouched by ulterior motives and thus a reliable source of knowledge was a successful presentation: his audiences approved. Angas first put his work into the public domain in Adelaide in an exhibition of his watercolours and sketches that opened in June 1845. The exhibition was well received and an extensive review praised him for being the first professional artist to have 'wandered among the savages' of New Zealand. ${ }^{98}$ As Angas was leaving Adelaide to exhibit in Sydney a reporter wrote, 'we need not say, how deserving this gentlemen is of all the support of the friends of these colonies, and of New Zealand. ${ }^{99}$

Reading beyond the packaging of his travel reveals a more complex colonial encounter. Angas was reliant on Maori and he travelled in a middle ground in which those who helped him also saw value in his project. But he was happy to transgress the rules of that middle ground when it suited him. He was also reliant on British people who were more directly part of the colonising of the region, and was significantly advantaged by his father's role in the South Australian Company. The way Angas presented his travelling was directly influenced by the colonial context in which he travelled. The knowledge he produced was colonial knowledge, for a colonising audience. The following two chapters explore how his identities as an artist and as a natural historian/ethnographer further contributed to the creation of particular forms of colonial knowledge in his work.

\footnotetext{
${ }_{95}$ Angas, The Kafirs Illustrated, v.

96 'The Late George French Angas,' South Australian Register, 8 October 1886, p.7, col.h.

${ }^{97}$ Michael Vanstone, "First Impressions," Adelaide Observer, April 1985, pp.4-5; "George French Angas, F.L.S," 7.

98 'Mr George French Angas's Exhibition of Water Colour Paintings,' South Australian Register, 21 June 1845, p 2, col.f p.3, col.b.

${ }^{99}$ South Australian Reporter, 'Domestic Intelligence' Sydney Morning Herald, 22 July 1845, p.3, col.e.
} 


\section{A 'Writer of Images': The Artist}

Central to George French Angas's claims to be providing a 'correct idea' of Maori, was the fact that he was making images. His project was more than 'mere description'. In his published works Angas identified himself most explicitly as an artist. Savage Life and Scenes was subtitled 'Being an Artist's Impressions of Countries and People at the Antipodes' and in the prefaces to both this work and The New Zealanders Illustrated he introduced himself as an artist. ${ }^{1}$ As he travelled with his sketchbook in hand, seeking out and engaging with people for the purpose of making images of them, it was his most visible role. An article in the Daily Southern Cross, for example, written while Angas was in New Zealand, described him as 'a very accomplished artist', and Te Wherowhero described him as a 'writer of images'. This chapter focuses on Angas's portraits, and in particular, the lithographs from the choreographed publication, The New Zealanders Illustrated. It looks at the multiplicity of contexts and influences that went into the creation of the images, from their beginning in Angas's encounters with the subjects, to their journey into the public domain as finished products. The portraits are read for the stories they tell about Angas's encounters in, and understandings of, New Zealand in 1844.

When, at the age of eighteen, Angas chose to leave his position in his father's business it was to his talents in drawing that he turned. His brother John was also a proficient artist so it is probable that some artistic encouragement and training was part of the Angas family childhood. From the eighteenth century, artistic pursuits were common amongst the more affluent sectors of English society. ${ }^{3}$ After training in natural history illustration,

\footnotetext{
${ }^{1}$ George French Angas, Savage Life and Scenes in Australia and New Zealand: Being an Artist's Impressions of Countries and People at the Antipodes, vol. I (London: Smith, Elder and Co., 1847), vii; George French Angas, New Zealanders Illustrated (London: Thomas McLean, 1847), Preface.

2 "Forthcoming Publication," Daily Southern Cross, 30 November 1844, p.2, col.c; George French Angas, Savage Life and Scenes in Australia and New Zealand: Being an Artist's Impressions of Countries and People at the Antipodes, vol. II (London: Smith, Elder and Co., 1847), 52; Angas, New Zealanders Illustrated, Plate XLIV.

${ }^{3}$ Michael Clarke, The Tempting Prospect: a Social History of English Watercolours (London: Colonnade Books, British Museum Publications, 1981), 103-4.
} 
Angas immediately put his new skills to use and combined them with travel when, in 1842, he published his illustrated travelogue of his time in Malta and Sicily. ${ }^{4}$

Three British artistic traditions set the context for the work that Angas produced in New Zealand, influencing what he chose to depict and how he depicted it. The first was the fine-art genre of portraiture. He also painted landscapes and buildings, but he came to New Zealand to depict the people. Thirty-one of the sixty plates in The New Zealanders were full-length portraits and only five plates did not include any people. Portraiture had a long and esteemed history in European art. ${ }^{5}$ Although the popularity of the landscape was on the rise in Britain in the mid-nineteenth century, portraiture remained very popular. ${ }^{6}$ Moreover, in the early-nineteenth century the genre was gathering new meanings. Capturing a 'likeness' had always been the defining characteristic of portraits, but they were increasingly being treated as biographical documents. ${ }^{7}$ Reflecting this trend, on 2 December 1856, less than a decade after Angas published his New Zealand works, the British National Portrait Gallery was established in London. The Gallery was sponsored by the state, and its purpose was to focus on the subjects of the portraits, not the paintings as works of art. $^{8}$

There were significant differences between Angas's portraits and works in this tradition. Many of these differences were expressed within the second tradition to influence Angas's images; watercolour painting. Easier to apply and much quicker to dry than oils, the traditional medium of portraits, watercolours allowed the artist to paint outside the studio. Out amongst nature, 'on the spot', people argued that the 'truth' of a moment could be captured. ${ }^{9}$ For this reason, watercolours had become the medium of natural history illustration and of the travelling artist. Angas emphasised that he made his paintings 'on the spot'. ${ }^{10}$ As portraits of indigenous people, Angas's portraits sat across the boundaries of these two genres. They were portraits and natural history and ethnographic illustration.

The third tradition to influence Angas was that of the picturesque. Although the term has acquired a pejorative implication in the present, understood as rendering a subject 'weak

\footnotetext{
4 John Tregenza, George French Angas: Artist, Traveller and Naturalist 1822-1886 (Adelaide: Art Gallery Board of South Australia, 1980), 7; George French Angas, A Ramble in Malta and Sicily, in the Autumn of 1841 (London: Smith, Elder and Co., 1842). Also see footnote 9 of Chapter One: 'Wandering on the Outskirts of Civilisation': The Traveller, 16. ${ }^{5}$ Roger Blackley, A Nation's Portraits, Art History Lecture Series 3 (Wellington: School of Art History, Victoria University of Wellington, 2005), 14.

${ }^{6}$ John Hayes, The Portrait in British Art (London: National Portrait Gallery, 1991), 22.

7 Blackley, A Nation's Portraits, 9, 14; Marcia Pointon, Hanging the Head: Portraiture and Social Function in Eighteenth-century England (New Haven and London: Yale University Press, 1993), 5; Joanna Woodall, "Introduction: Facing the Subject," in Portraiture: Facing the Subject, ed. Joanna Woodall (Manchester and New York: Manchester University Press, 1997), 5.

8 'Gallery History,' National Portrait Gallery, London; www.npg.org.uk/about/history.php, accessed on 8 May 2013

${ }^{9}$ Clarke, The Tempting Prospect, 33, 103.

${ }^{10}$ Angas, Savage Life and Scenes, 1847, I:vii; Angas, New Zealanders Illustrated, Preface.
} 
and superficial,' this was not always so. ${ }^{11}$ It was a very popular aesthetic in Britain in the early nineteenth century and a well-established and common convention for travellers of empire. ${ }^{12}$ Literally, meaning 'like a picture' or that which is worthy of being made into a picture, the picturesque has been notoriously hard to define and has been applied and understood in many different ways. When Angas described something as picturesque he generally meant that it was attractive, pretty or charming but was also unusual or exotic in some way.

When Angas arrived in New Zealand in 1844 other artists were producing portraits of Maori. ${ }^{13}$ Isaac Coates and Joseph Merrett were two artists known particularly for such work. Isaac Coates had arrived in New Zealand in about 1843 probably intending to settle, though he left in 1845. He made 'a precarious subsistence executing likenesses' including profile portraits of Maori. ${ }^{14}$ Merrett had settled in New Zealand in 1839 and married a Maori woman. As a 'Pakeha-Maori', he was both an insider and an outsider from Maori society. ${ }^{15}$ Angas's New Zealand encounter and the portraits he produced were unique for two reasons. Firstly, he was even more of an outsider than Coates and Merrett. Travelling for just four months and on the move almost constantly, the relationships he formed were very temporary. He never had any intention of doing more than visit New Zealand. Secondly, Angas was travelling for the purpose of creating products that he could sell to a British audience. Declaring his motto to be 'Nullo, dies sine linea' (not a day without a line drawn), he produced a large body of work designed to be a cohesive collection for exhibition and publication. ${ }^{16}$

Despite the fact that he was an outsider, or perhaps because of this, the majority of Angas's New Zealand portraits were products of a middle ground context in which Maori participated in the creation of the images. This was often not the case for colonial portraits. Merrett, for example, had resorted to spying through a window to obtain an image of Hone Heke. ${ }^{17}$ The New Zealanders also included an image of Heke, but Angas left no description of meeting him. Given the notoriety of Heke at the time, this is surprising and may indicate that Angas's portrait of Heke was also created outside a middle ground

${ }^{11}$ Sidney K. Robinson, Inquiry into the Picturesque (Chicago: University of Chicago Press, 1991), xii-xiii, 143.

12 Giselle Byrnes, Boundary Markers: Land Surveying and the Colonisation of New Zealand (Wellington: Bridget Williams Books, 2001). Byrnes described the picturesque as a frequently invoked convention by the surveyors she was studying.

${ }^{13}$ Iain Sharp, Heaphy (Auckland: Auckland University Press, 2008), 40-47.

${ }^{14}$ Frederick Tuckett to his brother, 13 December 1845, quoted in Dawn Smith, 'Isaac Coates: Artist,' Nelson Historical Society Journal 6, no. 3 (2000): 40-5.

${ }_{15}$ Roger Blackley, “The Portraits of Joseph Merrett,” Art New Zealand , no. 56 (Spring 1990): 84-5, 111.

16 Preface Angas, Savage Life and Scenes, 1847, I:vii.

${ }_{17}$ Blackley, "The Portraits of Joseph Merrett," 84 
agreement. ${ }^{18}$ For the most part however, like conventional British portraits, Angas's portraits were collaborations between artist and subject. ${ }^{19}$ Unlike conventional portraits, they were probably not the products of a commercial transaction. Angas's subjects were not paying him. It is possible that Angas paid them, but he does not mention this anywhere. The benefits for both sides, then, lay elsewhere.

Those who assisted Angas in his travelling, like Kahoki and Te Wherowhero, seemed to appreciate that he was a 'maker of images'. Further, Maori seemed to be attaching some of the same meanings to portraits as were held in the British portrait genre - as objects used for the 'projection and maintenance of social privilege' and as biographical documents that could stand in for the real person. ${ }^{20}$ When drawing Rangituatea of Ngati Maniapoto, Angas wanted him to wear his cloak. Rangituatea however, 'touched his meri poonamu, his tiki, and the ornament of boar's tusks about his neck, signifying that these were sufficient indications that he was a great rangatira. ${ }^{21}$

Angas revealed his admiration for Maori by also applying some of the same meanings of British portraits to his Maori portraits. In contrast to Angas's representation of his encounter with the 'savage life', his New Zealand portraits were predominantly of the Maori elite - as Angas wrote, 'the most important Chiefs, with their families'. ${ }^{22}$ They were of named individuals, located in space and time through the inclusion of details about their iwi and whakapapa. Six of the portraits in The New Zealanders included the subject's signature alongside Angas's. ${ }^{23}$ This was a departure from portrait conventions that indicates that Angas saw the paintings to be biographical documents to even greater degree than were British portraits.

Although Rangituatea did not want to wear his cloak for the portrait, the wearing of cloaks for the portraits was, in general, something that Angas and those sitting for the portraits were in agreement on. At some point, either before or during his time in New Zealand, Angas developed a particular interest in Maori cloaks. A notable feature of his work was his interest in the ways that bodies were clothed. Angas found the cloaks to

\footnotetext{
18 Angas, New Zealanders Illustrated, Plate I.

${ }_{19}$ Blackley, A Nation's Portraits, 14; Jane Lydon, Eye Contact: Photographing Indigenous Australians (Durham: Duke University Press, 2005), xiii. Lydon discusses a similar "dynamic and performative relationship" between the artist and the subject.

See also Conal McCarthy, Exbibiting Maori: a History of Colonial Cultures of Display (Oxford and New York: Berg, 2007), 11, 28. McCarthy discussed the role that Maori had in the process of the display of their culture, seeing it as a way of exhibiting status and prestige.

${ }^{20}$ Blackley, A Nation's Portraits, 14; Woodall, "Facing the Subject," 5. Joanna Woodall noted the correlation between social elites and portrait subjects and used the phrase "the honorific elite eligible for portrayal."

21 Angas, Savage Life and Scenes, 1847, II:72. Original italics.

22 Angas, New Zealanders Illustrated, Preface.

${ }^{23}$ Ibid., Plates XIX, XXXV, XL, XLIX, XLVIII.
} 
'display great ingenuity and taste in their fabrication'. He believed the making of cloaks to be a dying art and wanted to record them before the art died out. ${ }^{24} \mathrm{He}$ lamented the use of woollen blankets rather than traditional cloaks or mats, describing the blankets as 'unwholesome', and as harbouring vermin and irritating the skin. ${ }^{25}$ Many people who he drew were happy to be portrayed in their cloaks. In the Waikato for example, when Angas met Te Paki, 'the old chief next in importance in the Waikato district to Te Wherowhero' and his wife, he wrote that they had already 'arrayed themselves in their primitive costume, for the purpose of sitting to me for their portraits' [sic]. ${ }^{26}$

There were also profound differences in understanding about the nature of the portraits. In Savage Life, Angas narrated an incident that took place a few days after he had been to Te Heuheu's pa. Angas attempted to place an image of Te Heuheu under the cooking shed to keep it out of the rain. E Para, Angas's guide, protested and Angas became 'vexed' and threatened to burn the picture. At this threat E Para 'was dreadfully shocked, and talked of writing a flax letter, to be sent off immediately, informing the great chief of my wickedness. ${ }^{27}$ To Angas, these portraits, once made, were objects separate in their existence from the subject of the painting. To Maori, this was not so. Portraits showed the head, the most sacred part of the body. They were therefore taonga and tapu. To put the portrait of a leader as powerful as Te Heuheu under a cooking shed would have been a gross insult.

The completed and lithographed portrait of Te Wherowhero demonstrated some of the mixtures of meanings created in the context of the exchanges (see Fig. 5). When Angas and Forsaith arrived to meet with him, Te Wherowhero did not move from where he had been sitting. Thereafter he was occupied in conversation with Forsaith and paid little attention to Angas. Angas had no say in how Te Wherowhero was clothed or positioned. In the portrait therefore, Te Wherowhero sits outside wrapped in a blanket, leaning against a log. This was not a pose in which a British political leader would have been portrayed. In the British portrait genre this posture, huddled with the blanket clutched about him, was associated with wretchedness, poverty, or madness. ${ }^{28} \mathrm{Te}$ Wherowhero however, is the central subject of the image. Beneath the blanket, he leans on the log with an air of ownership. His head is held high, and his gaze is strong. Angas encouraged this

24 Angas, Savage Life and Scenes, 1847, I:321.

25 Ibid., I:318.

26 Angas, Savage Life and Scenes, 1847, II:40.

27 Ibid., II:133.

${ }^{28}$ Jonathan Andrews, “The (Un)Dress of the Mad Poor in England, c.1650-1850. Part 1.," History of Psychiatry 18, no. 5 (2007): 5-24. 
reading of the image as being of someone important with the accompanying text in New Zealanders, describing Te Wherowhero as 'the most important man of all the Waikato tribes' with 'almost unlimited influence amongst his people'. ${ }^{29}$

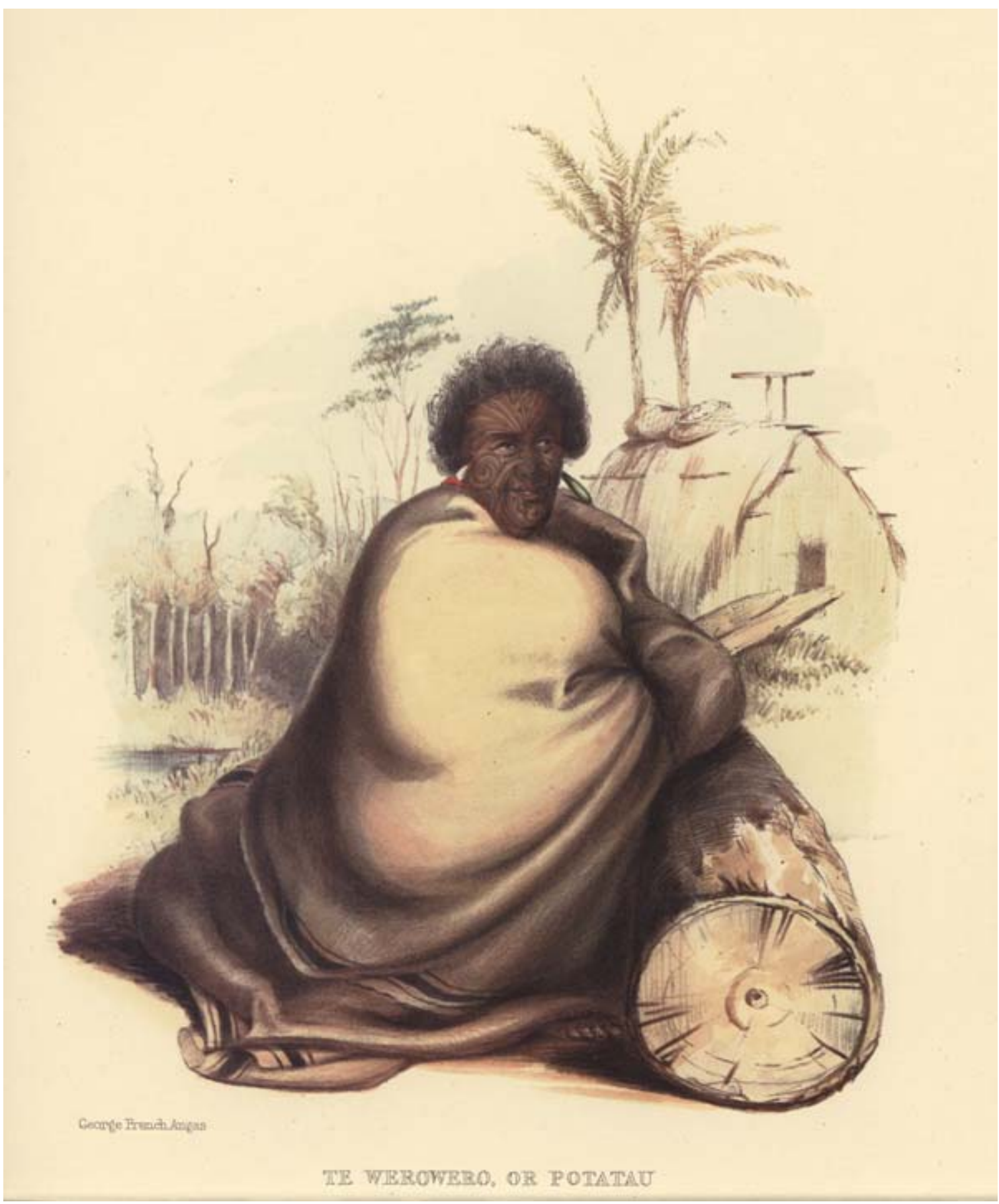

Figure 5: George French Angas, 'Te Wherowhero or Patuatu (Potatau): The Principal Chief of all Waikato', lithographed by George French Angas, The New Zealanders Illustrated, 1847, Plate XLIV.

${ }^{29}$ Angas, New Zealanders Illustrated, Plate XLIV. 
Angas travelled long distances in a short period of time in New Zealand and, despite his claims that his images were made 'on the spot', he did not have time to complete them until he had taken them out of New Zealand. Completing paintings in the studio was a common practice amongst travelling artists. Angas's paintings were still not finished when they were first exhibited in June 1845 in Adelaide. ${ }^{30}$ They were, therefore, works in progress as they moved out of the middle ground and into a cultural setting in which Angas had more control. Unlike most conventional British portraits, there was a strong chance that the subjects would never see them again. With over two years between making his sketches and the publication of the final lithographed product in The New Zealanders, Angas had time to receive, and respond to, feedback. The works travelled from one side of the world to the other, being exhibited in the colonial centres of Adelaide and Sydney and then in the imperial centre of London. People who saw his sketches and his paintings in progress, those who helped him organised the exhibitions, the lithographers and the publishers, would all have had some input into the form in which his work entered the public domain. The portraits in The New Zealanders, already shaped by the mixtures of meanings generated by artist and subject, were further shaped by British cultural influences of various kinds.

Angas's portraits consisted of a number of recurring poses. For groups he used differentiation in height and depth in ways that were designed to lead the eye neatly around the picture. In traditional British portraits these poses were also used as signals of status or of relations of power between the sitters. In Angas's work however, the poses were just as likely to have been determined by the subjects for different reasons. Moreover, the watercolours and lithographs do not necessarily reflect what Angas actually encountered. Plate V of The New Zealanders, for example, is of Te Awaitaia and Te Moanaroa, both chiefs of the Waingaroa area (see Fig. 6). In his account of events in Savage Life, Angas discussed meeting these men on different days. ${ }^{31}$ In this case the professed 'careful' and 'faithful' nature of his images was subordinated to aesthetic conventions. The viewer does not know if Te Awaitaia and Te Moanaroa would have chosen to be together in a portrait.

30 'Mr George French Angas's Exhibition of Water Colour Paintings,' South Australian Register, 21 June 1845, p 2, col.f p.3, col.b.

31 Angas, Savage Life and Scenes, 1847, II:59-64. 


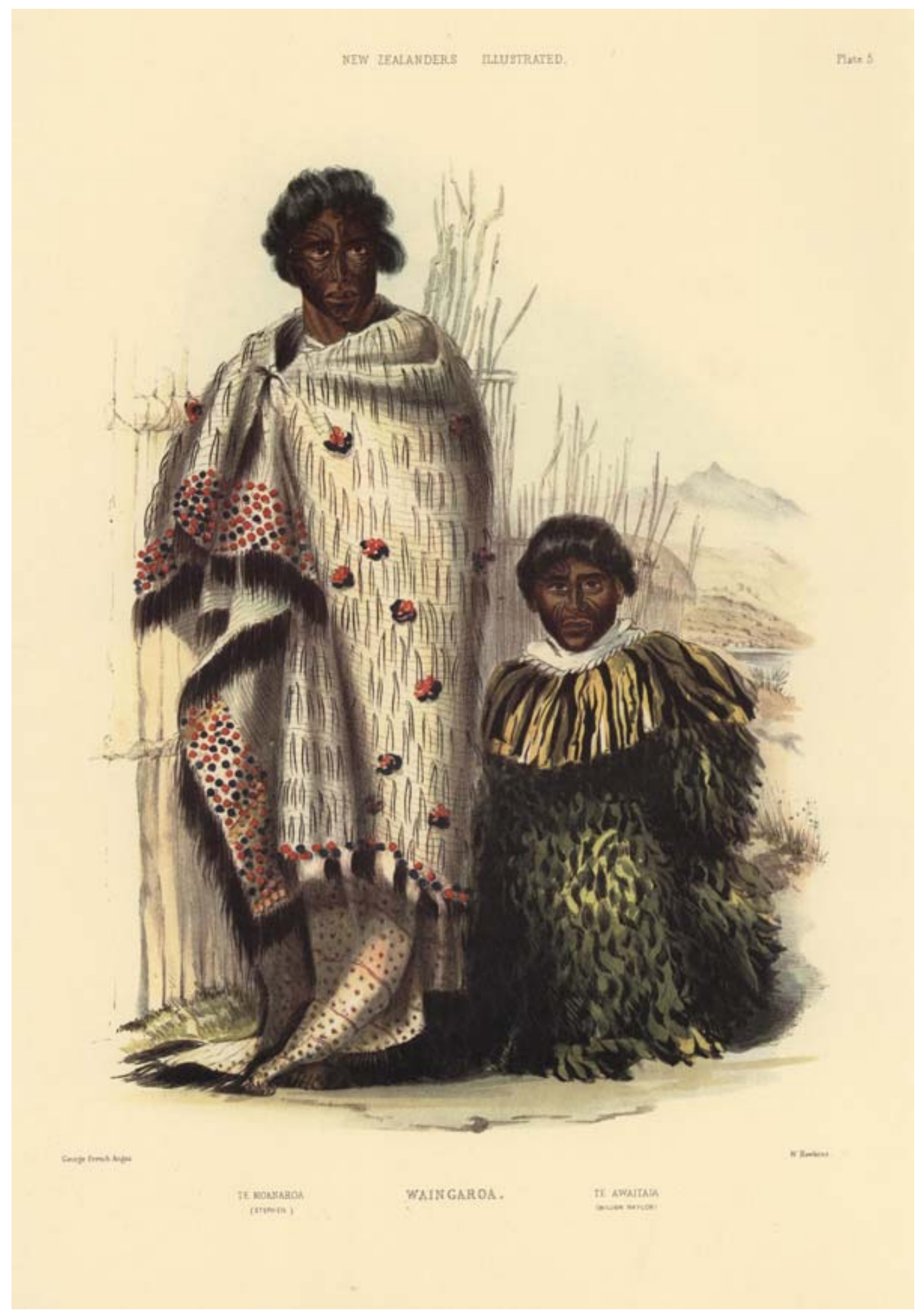

Figure 6: George French Angas, 'Waingaroa. Te Moanaroa (Stephen); Te Awaitaia (William Naylor)', lithographed by W. Hawkins, The New Zealanders Illustrated, 1847, Plate V.

As well as influencing what Angas made images of in the first place, the picturesque aesthetic also informed his selection of images for The New Zealanders. . The women in the lithographed portraits had large liquid eyes, long flowing locks, rosy cheeks and rosebud 
mouths. The men were, on the whole, handsome, standing tall and exotic in their elaborate cloaks. The children had large eyes and rosy cheeks and were described as having 'natural gaiety and wit' and as 'gay, lively young creatures'. ${ }^{32}$

As Jeffrey Auerbach described in relation to Angas's landscape paintings, the picturesque in the context of empire was about the domestication of the exotic, homogenising and removing aspects of 'difficult otherness'. ${ }^{33}$ While much of the knowledge created by the British about contact zones created difference, this was an example of the 'construction of affinities' ${ }^{34}$ Angas wanted to construct affinities in New Zealand. He was a supporter of the policy of amalgamation. In Savage Life and Scenes, he wrote of a desire 'that the natives and settlers may live and amalgamate together, so as to form a powerful and a distinguished nation, combining the good qualities, physical and moral, of two fine races of men'. He called on George Grey, governor of New Zealand by the time Angas was back in England publishing, to use 'wise and prudent legislation' to ensure that this happened..$^{35}$ Grey was the 'Great Amalgamator' and Angas was travelling and publishing in the 'halcyon days of amalgamation'. ${ }^{36}$

Angas's support for amalgamation included biological amalgamation and he also found the children from marriages between Maori and Pakeha to be picturesque. They were 'the finest race of half-castes, perhaps, in the world' ${ }^{37}$ Three of his lithographs in The New Zealanders were of these 'half-castes'. James Maxwell, son of Ngeungeu and her English husband was described as an 'interesting' child. George Thoms, the son of the whaler Jordy Thoms and his unnamed Maori wife, the sister of Te Rauparaha, was a 'universal favourite amongst' the Ngati Toa. The third was Aitu, one of 'A Group at Te Aro Pah, Port Nicholson'.38

It was Angas's portraits of women which were particularly created within a picturesque aesthetic. In The New Zealanders, while only one quarter of the total number of portraits were of women, nearly three-quarters of these were young and attractive. Similarly, Savage

\footnotetext{
32 Angas, New Zealanders Illustrated, Plates XII and XXXIII.

33 Jeffrey Auerbach, "The Picturesque and the Homongenisation of Empire," The British Art Journal 5, no. 1 (Spring/Summer 2004): 53. See also David Cannadine, Ornamentalism: How the British Saw Their Empire (London: Allen Lane, 2001) xix.

34 James A. Boon, Affinities and Extremes: Crisscrossing the Bittersweet Ethnology of East Indies History, Hindu-Balinese Culture, and Indo-European Allure (Chicago: University of Chicago Press, 1990); Auerbach, "The Picturesque and the Homongenisation of Empire," 53.

35 Angas, Savage Life and Scenes, 1847, I:339.

${ }^{36}$ Damon Ieremia Salesa, "Race Mixing: A Victorian Problem in Britain and New Zealand, 1830s-1870" (PhD, Faculty of Modern History, University of Oxford, 2000), 107, 122.

37 Angas, Savage Life and Scenes, 1847, I:310-1.

38 Angas, New Zealanders Illustrated, Plates III, XII, XL.
} 
Life and Scenes had descriptions of women who were 'pretty', 'pleasing', 'comely', and of 'gipsy like beauty. ${ }^{39}$ Leonard Bell noted the similarity between Angas's portraits of women and those in the popular periodical Heath's Book of Beanty (1833-47), a 'repository of the so-called keepsake beauty type' (see Fig. 7). ${ }^{40}$

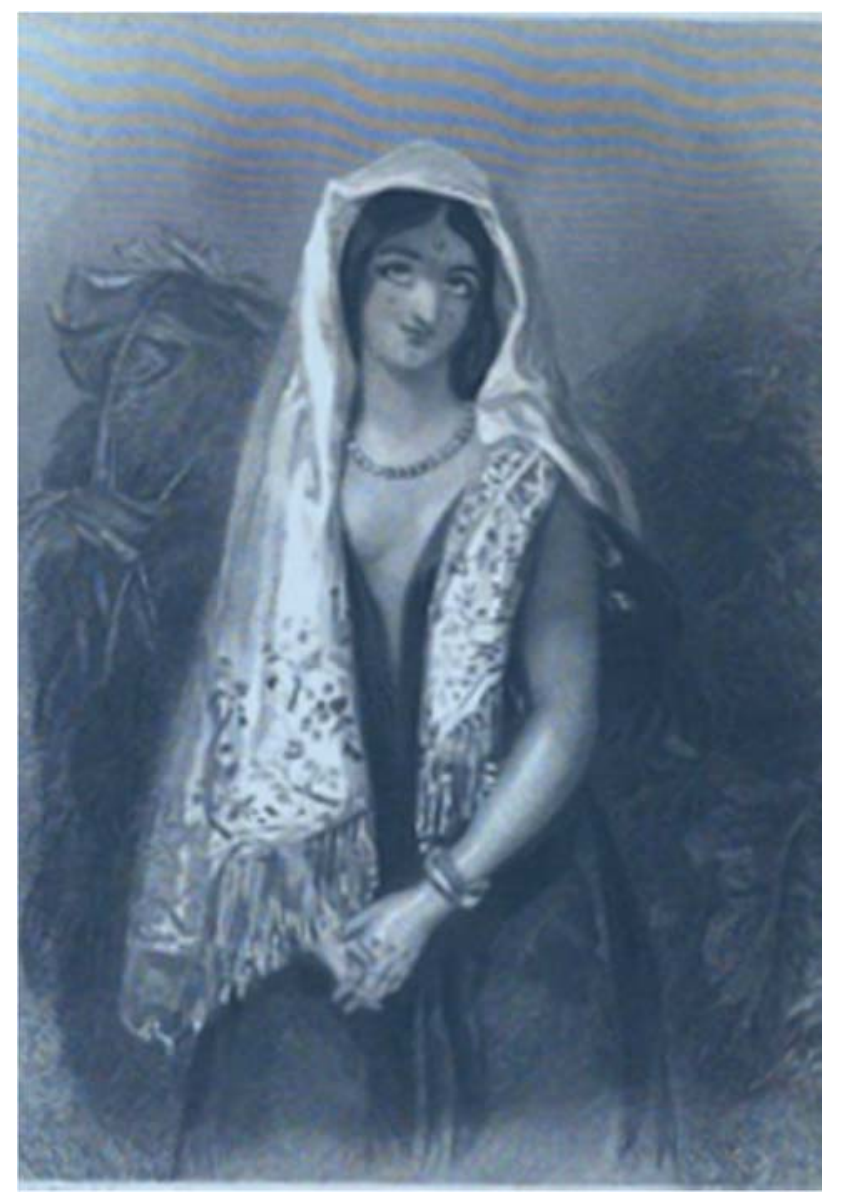

Figure 7: 'Aisha', Heath's Book of Beauty, London, 1838, p. 166.

One way in which the picturesque in Angas's work can be examined is in terms of what Mary Louise Pratt has called 'transnational erotics' - the sexualisation of female bodies beyond the borders of Europe. For millennia Europe had been fascinated with the bodies of women who lived outside of Europe and in the context of empire this had increased. ${ }^{41}$ From the time of Cook's voyages and the subsequent circulation of journals and images,

\footnotetext{
${ }^{39}$ Angas, Savage Life and Scenes, 1847, I:311; Angas, Savage Life and Scenes, 1847, II:41.

${ }^{40}$ Leonard Bell, Colonial Constructs: European Images of Maori, 1840-1914 (Auckland: Auckland University Press, 1992), 18.

${ }^{41}$ Kathleen Wilson, "Empire, Gender and Modernity in the Eighteenth Century," in The Oxford History of the British

Empire: Gender and Empire, ed. Philippa Levine (Oxford: Oxford University Press, 2004), 29.
} 
the beautiful sexually willing young maiden of the South Pacific, especially the Tahitian, was a well-established object of European fantasy. ${ }^{42}$

Though New Zealand was not a destination famous primarily for its beautiful women and sexual possibilities, by the time Angas was travelling there had been plenty of European men who had enjoyed New Zealand as a place of sexual encounter with women. As a young man travelling far from home it would not have been unusual for Angas to have had intimate encounters in New Zealand, but he is silent on this possibility, perhaps influenced by the protestant morality of people like his father who would have made up some of his hoped for audience. Whatever his personal interests or involvements, Angas was making images for an audience who were keen to see exotic, beautiful women.

At his first exhibition, in Adelaide in July 1845, Angas's audience expressed approval of the way he had presented the women of New Zealand in his watercolours. A reviewer wrote:

as represented by Angas, they all seem to have an innocent playfulness, or what some, perhaps, might call a roguish leer in the eye. We are not peculiar in this opinion, having heard it remarked by many others in the room. We mention this, not with the view of doubting the strict accuracy of the paintings, but only as pointing out the difference between the New Zealand women and the native women of the Australian continent. ${ }^{43}$

This 'communication circuit' between Angas and his audience seems to have had an impact on the process of the portraits becoming lithographs. ${ }^{44}$ Some of the images of young women were altered in ways that moved the exotic in the direction of the erotic. The most obvious example of this is that of $\mathrm{E}$ Wai and Kahoki. In the original watercolour, though still conforming to picturesque ideals - the large eyes, the rosy cheeks - they have two distinct personalities (see Fig. 8). E Wai, described in the text as 'bashful and retiring' crouches in way that conveys these qualities, and Kahoki, described by Angas as 'a woman of strong mind, with a proud and queenly bearing', who, 'by her powerful talents, combined with her high birth, possesses an almost unlimited influence amongst her people', gazes confidently beyond the artist/viewer.

42 Ann Laura Stoler, Carnal Knowledge and Imperial Power: Race and the Intimate in Colonial Rule (Berkeley: University of California Press, 2002), 43; See also, for a more detailed examination of this, Patty O’Brien, The Pacific Muse: Exotic Femininity and the Colonial Pacific (Seattle: University of Washington Press, 2006).

43 'Mr George French Angas's Exhibition of Water Colour Paintings,' South Australian Register, 21 June 1845, p.2, col.f p.3, col.b.

${ }^{44}$ James A. Secord, "Knowledge in Transit," Isis no. 95 (2004): 668. 


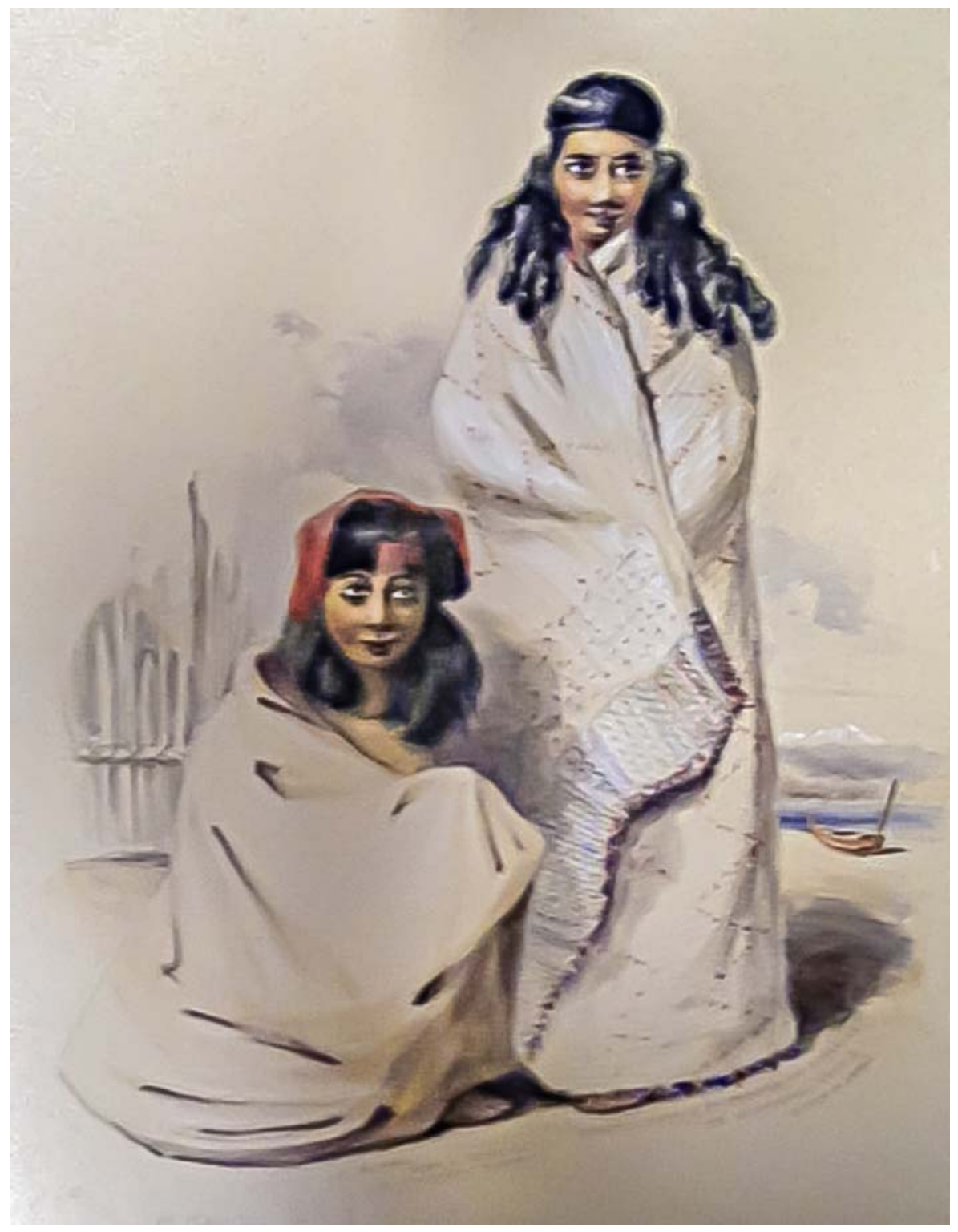

Figure 8: George French Angas, 'E Wai. Wife of 'Tuarau the son of Na Horua or Tom Street. Kahoki. Niece of Rauparaha. and daughter of Te Wehiarangi. Chief of Roturua Lakes.', 1844, watercolour, $33 \times 24.5 \mathrm{~cm}$, AA 8/6/5, SAM.

In the lithograph, made by W. Hawkins, E Wai's right leg was repositioned slightly (see Fig. 9). There was a subtle shift from a shy crouch, to a more confident and suggestive reclining pose. Kahoki, with her eyes widened, was transformed into the less confident looking one. Whether this change was the work of Angas or W. Hawkins is not known. Angas was involved in the lithography process and did some of the lithographs for The New Zealanders himself. It is very possible therefore that he played some role in the alteration. ${ }^{45}$

\footnotetext{
${ }^{45}$ Bell, Colonial Constructs, 11.
} 


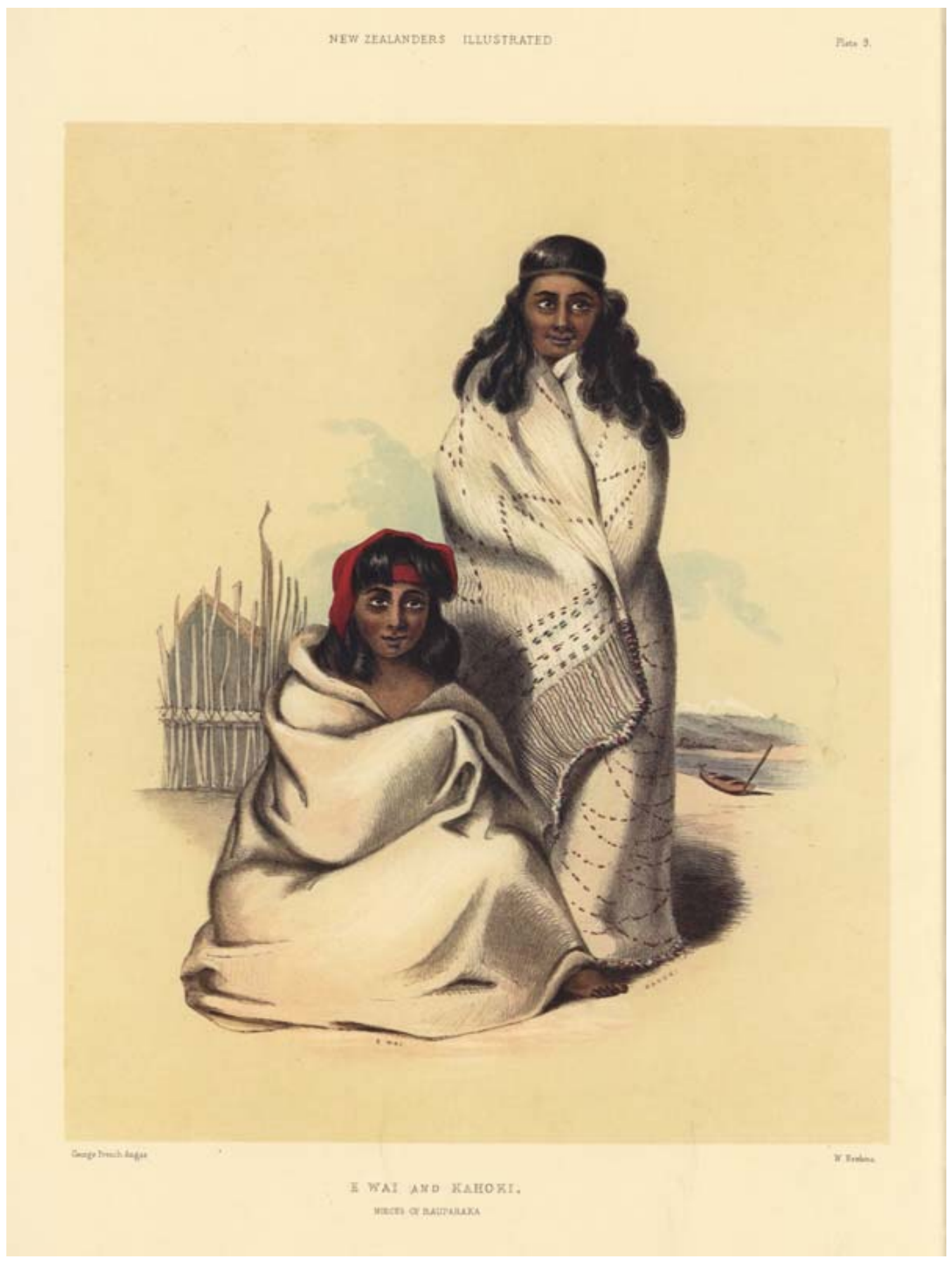

Figure 9: George French Angas, 'E Wai and Kahoki, nieces of Rauparaha', Lithographed by W. Hawkins, The New Zealanders Illustrated, London, 1847, Plate IX.

Despite these changes, the sexuality of the women is still relatively muted. There may have been suggestions of naked skin beneath the cloaks but they were always modestly covered. Angas painted women with bared breasts but only when they were in the distance, not in the close up encounters of the portraits. Philippa Levine argued that in European representations, 'a lack of clothing among colonised individuals...connoted 
primitiveness and savagery. ${ }^{46}$ These women were not savage. In the text that accompanies the images in The New Zealanders, and in Savage Life and Scenes, Angas presented the women of New Zealand as chaste, with 'correctly' feminine behaviour. Ngeungeu, for example, the subject of the first female portrait in The New Zealanders, was 'highly respected for the propriety of her conduct', and was 'very neat in her habits. ${ }^{47}$ These were women who would make good wives and mothers in an amalgamated New Zealand colony.

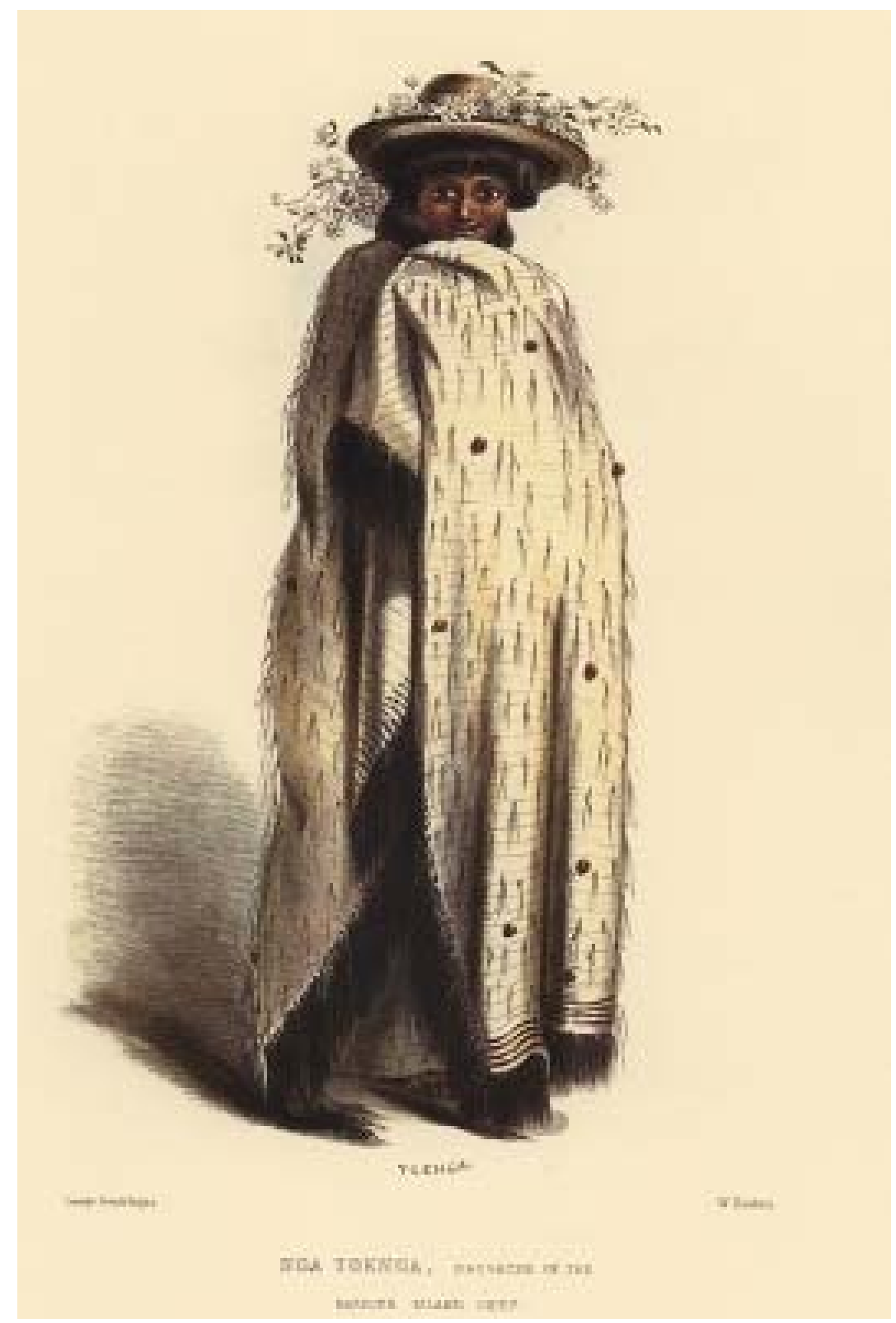

Figure 10: George French Angas, 'Nga Toenga, daughter of the Barrier Island Chief', lithographed by W. Hawkins, The New Zealanders Illustrated, London, 1847, Plate VII.

${ }^{46}$ Philippa Levine, "States of Undress: Nakedness and the Colonial Imagination," Victorian Studies 50, no. 2 (Winter 2008): 189.

${ }^{47}$ Angas, New Zealanders Illustrated, Plate III. 
Angas found Maori women to be at their most picturesque when they were engaging with British culture. In another example of sartorial colonisation in his work, this included their engagement with European clothing. The portrait of Nga Toenga was an example of one of the charming young girls he met who had bought European hats and adorned them with clematis flowers, to 'picturesque and not unbecoming effect' (see Fig. 10). ${ }^{48}$ In describing another young woman Angas met, he wrote 'this gay damsel was...a very pretty girl who knew how to set off her charms to advantage; for, over a European dress, she had retained her native ornaments, and wrapped herself coquettishly in a beautiful kaitaka, displaying her large hazel eyes above its silky folds' ${ }^{49}$ In contrast, Augustus Earle wrote in 1827 that 'in many instances, [women in New Zealand] quite spoil their good looks, by half adopting the European costume. ${ }^{50}$

There were alternative forms of femininity in New Zealand that Angas could have depicted. John Gilfillan, drawing in Whanganui river villages in the early 1840s, made a sketch that showed a woman leading the haka and one of Merrett's pictures showed a female priestess leading a tapu lifting ceremony. ${ }^{51}$ Angas did include a 'celebrated priestess' in The New Zealanders, but she sits obscurely behind another figure and he does not write about her in any detail. ${ }^{52} \mathrm{He}$ also included an 'aged slave woman' in one of his lithographs. This was not a portrait, however, but part of a display of 'Implements and Domestic Economy'. ${ }^{53}$

There were limits and exceptions to Angas's approval of Maori engagement with European culture and these also influenced the images he made and the way they were presented. Linda Nochlin argued that in the use of the picturesque there was a more sinister meaning. 'Only on the brink of destruction,' she wrote, 'in the course of incipient modification and cultural dilution, are customs, costumes and religious rituals of the dominated finally seen as picturesque. ${ }^{54}$ In Angas's work his support for amalgamation manifested as admiration for Maori individuals but also in a belief that Maori culture was dying in the face of the stronger British culture.

48 Angas, Savage Life and Scenes, 1847, I:292.

49 Ibid., I:239.

50 Augustus Earle, ENZB - A Narrative of a Nine Months' Residence in New Zealand in 1827 (London: Longman Rees, Orme, Brown, Green and Longman, 1832), 49.

51 Judith Binney, "Kawanatanga and Rangatiratanga: 1840-1860," in The People and the Land: An Illustrated History of New

Zealand, 1820-1920: Te Tangata Me Te Whenua, ed. Judith Binney, Judith Bassett, and Erik Olssen (Wellington: Bridget

Williams Books, 1993), 85-87.

52 Angas, New Zealanders Illustrated, Plate XXXVI.

53 Ibid., Plate LV.

${ }^{54}$ Linda Nochlin, The Politics of Vision: Essays on Nineteenth-Century Art and Society (New York: Thames and Hudson, 1989), 50 . 
Another manifestation of the limits of Angas's approval of Maori engagement with European culture was in the decisions about which watercolours were made into lithographs for The New Zealanders; which ones represented the 'correct idea' Angas wanted to provide. The portrait of Rora Pare, who Angas painted at the Ashwell's mission station on the Waikato was not included (see Fig. 11). She was fully clothed in European dress and may have been considered to be too Europeanised and lacking in the exotic. In his notes on the watercolour Angas described her as 'a regular vixen', so she may also have been considered too untamed in her sexuality. Another omission was the portrait of Josiah Taonui. In full European dress and with no moko, he may also have been too Europeanised. The use of the picturesque tamed the extreme elements of the exotic, but was also dependent on some exoticism.
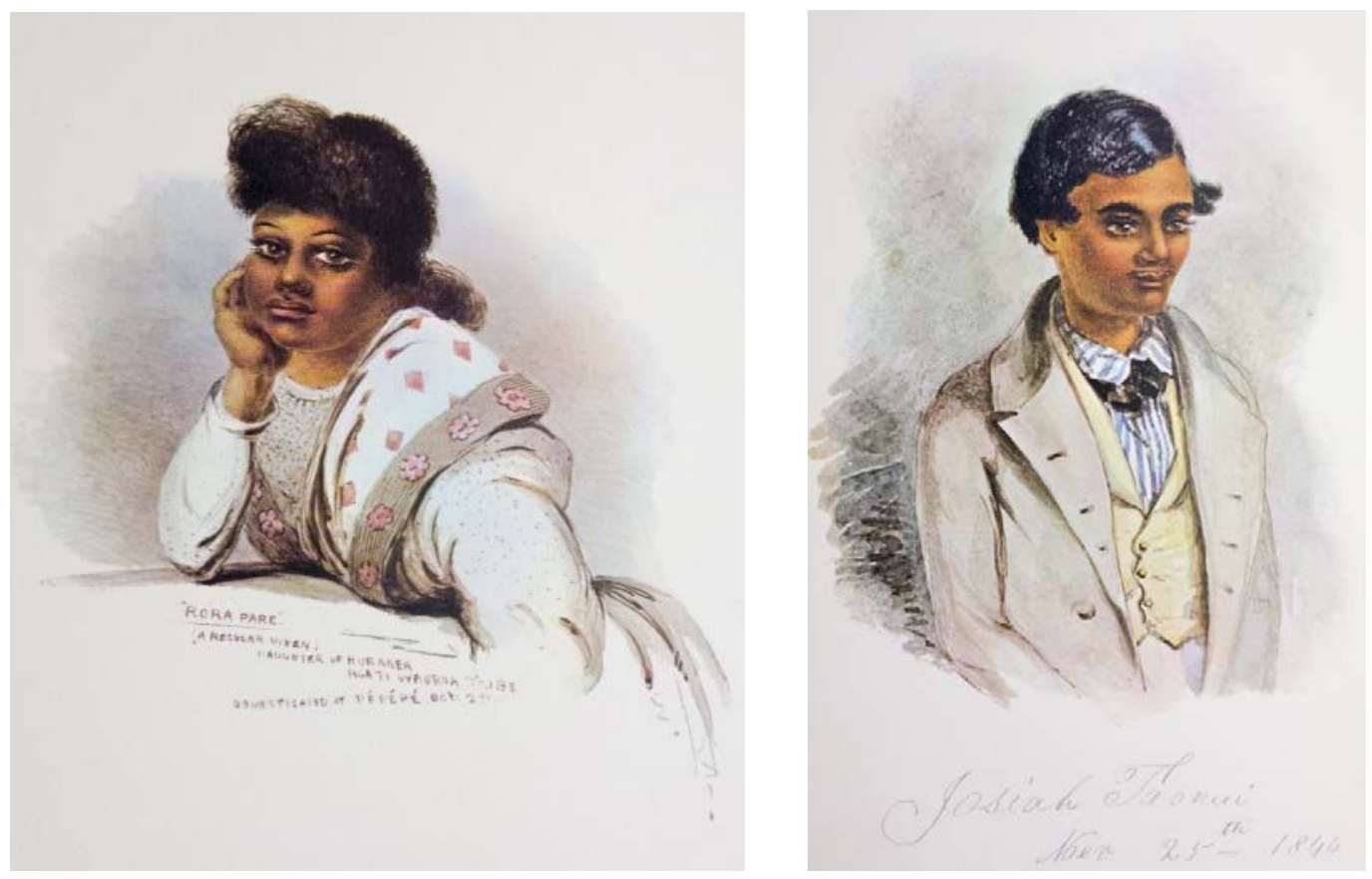

Figure 11: George French Angas,' Rora Pare." (A regular vixen) Daughter of Hurakea Ngati Wauroa Tribe Domesticated at Pépépé: Oct: 2nd', watercolour, 280x220 mm, 1844, AA, 8/7/25, George French Angas Collection, SAM; George French Angas, 'Josiah Taonui. Nov 25 ${ }^{\text {th }}$ 1844,' watercolour, 250x155 mm, AA 8/7/18, George French Angas Collection, SAM.

In The New Zealanders, Ko Nga Waka Te Karaka, 'a Christian chief of the Waikato,' who Angas met and painted while in Auckland, was depicted dressed fully in European clothes (see Fig. 12). There are two crucial details in the image, however - Te Karaka's buttons were not done up correctly and he was not wearing socks. This may well have been what he was actually wearing and how he was wearing it. Moreover, Te Karaka would have been dressed as he was for his own reasons. Clothes worn by indigenous peoples were a 
'careful mixture of old and new meaning' and the choice to wear European clothes was made "with a clear idea of what they were doing and for specific political reasons. ${ }^{55}$ But clothes were very important symbols in the Empire, as Angas knew. There was what Levine called a 'precisely calibrated link between clothing and rank. ${ }^{56}$ How clothing was worn was just as important as what was worn - whether it was dirty, ill-fitting, or done up crookedly for example. ${ }^{57}$ The missing socks and the mismatched buttons were loaded with culturally significant meanings that the intended British audience would have understood.

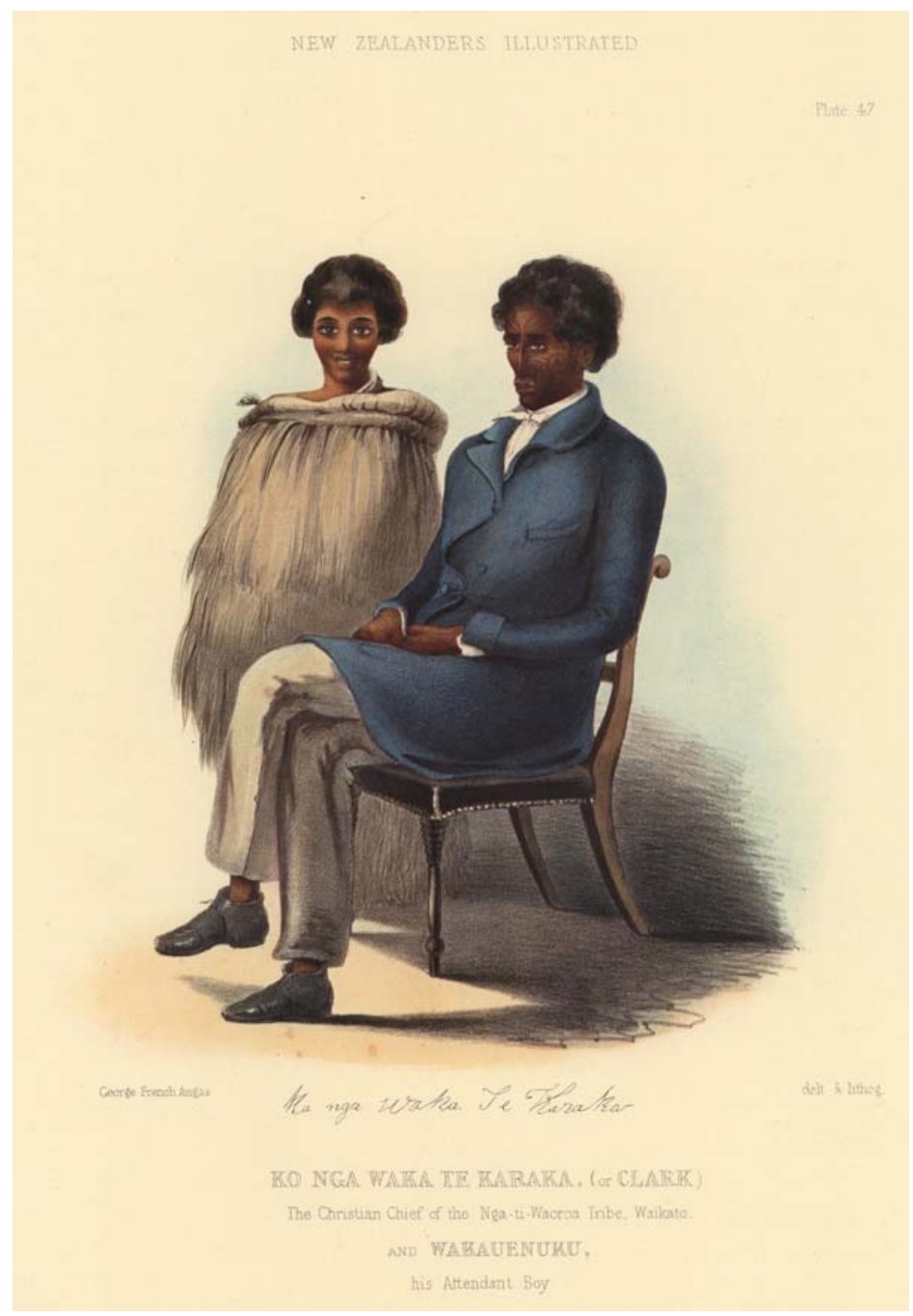

Figure 12: George French Angas, 'Ko Nga Waka Te Karaka, (or Clark). The Christian Chief of the Nga-ti-waoroa Tribe, Waikato. And Wakauenuku, his Attendant Boy.', lithographed by George French Angas, The New Zealanders Illustrated, Plate XLVII.

55 Robert Ross, Clotbing: a Global History, or The Imperialists' New Clothes (Cambridge: Polity, 2008), 95, 170.

${ }^{56}$ Levine, "States of Undress," 209. See also Helen Callaway, "Dressing for Dinner in the Bush: Rituals of SelfDefinition and British Imperial Authority," in Dress and Gender: Making and Meaning in Cultural Contexts, ed. Ruth Barnes and Joanne B. Eicher, Paperback ed. (Providence: Berg, 1997), 246; Bernard S. Cohn, "Cloth, Clothes and Colonialism: India in the Nineteenth Century," in Cloth and Human Experience, ed. Annette Weiner and Jane Schneider (Washington: Smithsonian Institution Press, 1989), 8.

${ }^{57}$ Patrizia Calefato, The Clothed Body (Oxford and New York.: Berg, 2004), 8. 
One of the most common subjects of humour in Angas's narrative was attempts by Maori to wear European clothes. Pretty women were made more attractive by such attempts, but men, older women and children were not. There were numerous incidents at which Angas could not help but 'indulge in a hearty laugh.' One he told was about one of his 'helps', who rejoiced in "the singular name of "troutete" or trousers, from his having appropriated to his own use a pair of those peculiarly European articles of dress'. ${ }^{58}$

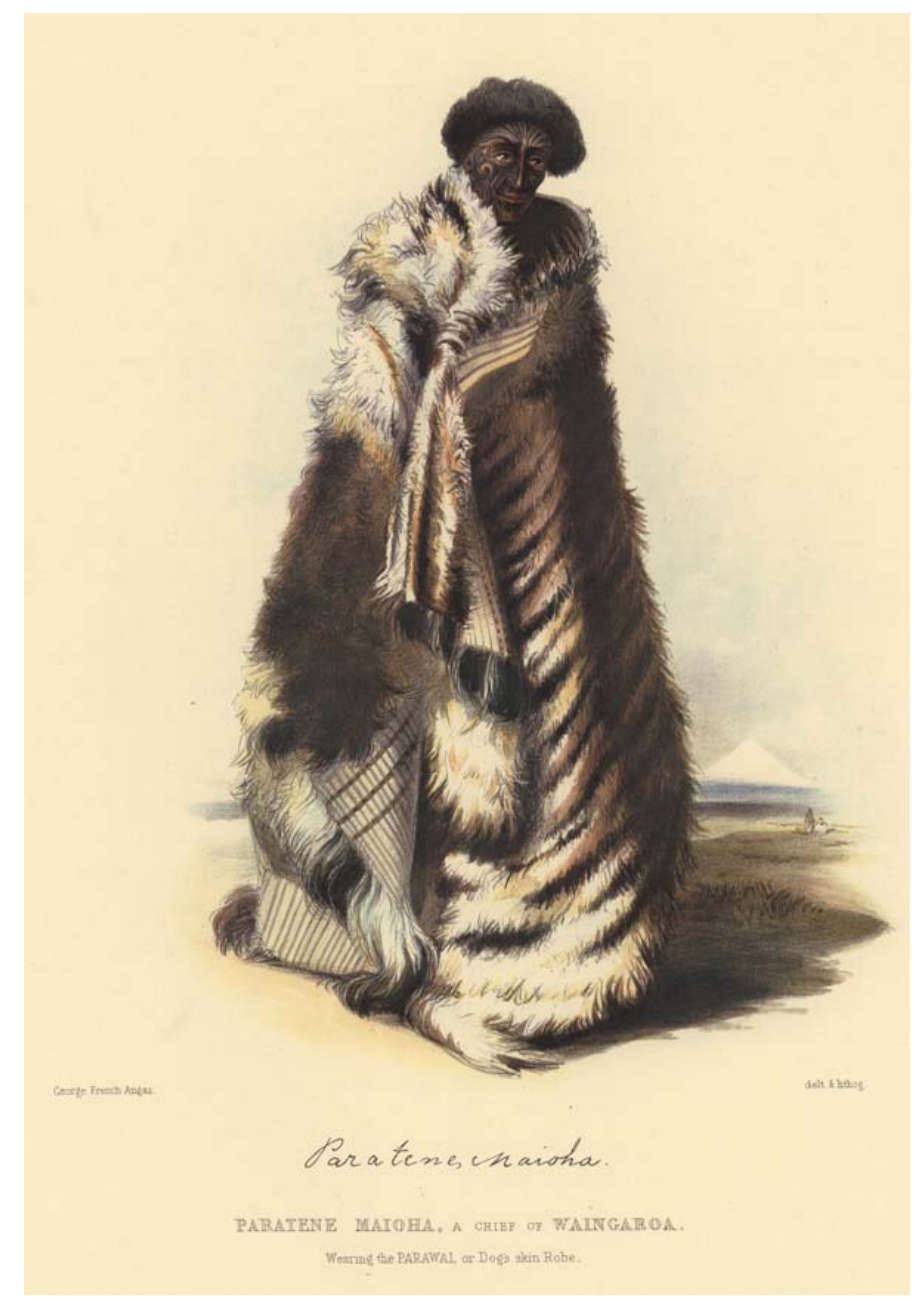

Figure 13: George French Angas, 'Paratene Maioha, a Chief of Waingaroa,' lithographed by George French Angas, The New Zealanders Illustrated, 1847, Plate XXXV.

In his presentation of his images, Angas also used humour to distance himself from the middle ground. He denied the middle ground context of their creation and he delegitimised the right of the subjects to participate in the process. In Waingaroa, Angas drew Paratene te Maioha, a cousin of Te Wherowhero and a chief of the Waikato (see Fig. 13). Angas described Paretene as 'a sensible and intelligent man, and much esteemed by

\footnotetext{
58 Angas, Savage Life and Scenes, 1847, II:72 Original italics.
} 
those Europeans to whom he is known.' The portrait of Paratene in The New Zealanders included his signature. But when Paratene took an interest in the way he was to be displayed, rather than accepting this as part of the process of sitting for a portrait, Angas made Paratene an object of humour. Angas narrated:

He desired to be excused for a few moments; having gained his point, he sought an interview with Mrs. Wallis, the missionary's wife... and prefacing his request with some solemn intimations of its paramount importance, begged "Mother" to lend him a looking-glass, that he might compose his features in a manner suitable to his own ideas of propriety ere he took his stand before the easel of the artist! ${ }^{59}$

In another incident, a woman who Angas met while travelling with Forsaith, recorded only as the wife of Haimona, 'insisted, to my great dismay, in robing herself for the occasion in a clean white chemise of European fashion; and putting aside her native habiliments, down she lay upon the wet ground thus attired ${ }^{60}$ He laughed at the idea of a European lady acting in such a manner.

Angas continued to create works of art throughout his life though on a less prolific scale than in the years 1844-9. In 1952 a series of advertisements appeared in New Zealand newspapers for a book called The Wanderings of the Wanderer by John Webster. The advertisements highlighted Angas's role as the lithographer and colourer of Webster's illustrations. ${ }^{61}$ Although the book was not published in the end, this demonstrated that Angas's name was considered marketable. In 1852 he painted two more New Zealand portraits of Tamihana Te Rauparaha. ${ }^{62}$ Angas also illustrated books for other authors such as John George Wood. ${ }^{63}$

Savage Life and Scenes was an entertaining read, but it was his illustrations that have engaged people, and which made the Egyptian Hall exhibition in London in 1846 one the 'Easter attractions'. Many academics have dismissed the images as being overly influenced by the picturesque, but a closer examination reveals many more layers of influence and meaning. The subjects of the images were crucial to the creation of the sketches. Outside of the period of creation however, the choices Angas made about what drawings became

59 Angas, New Zealanders Illustrated, Plate XXXV; see also Angas, Savage Life and Scenes, 1847, II:59.

${ }^{60}$ Angas, Savage Life and Scenes, 1847, II:12. Original italics.

${ }^{61}$ 'New Illustrated Work,' Daily Southern Cross, 16 November 1852, p.1, col.3.

${ }^{62}$ George French Angas, 'Tamihana Te Rauparaha, 1852, watercolour, C-114-001, ATL; George French Angas,

'Tamihana Te Rauparaha, 1852, watercolour, C-114-002, ATL.

${ }^{63}$ John George Wood, The Natural History of Man (London: George Routledge \& Sons, 1868). 
paintings, what paintings became published lithographs, and the way he presented the images was part of a story he was telling about what should happen in New Zealand. They told a story of a people who were admirable and worthy of being the subject of a named portrait, but who were not British and who would benefit from adopting British culture and mixing their blood with British blood. This theme is further explored in the following chapter which focuses on Angas's role as a natural historian and ethnographer. 


\section{'A faithful describer': The Natural Historian \& Ethnographer}

In the preface to The New Zealanders Illustrated George French Angas explained that he had gathered his information about Maori 'carefully and faithfully'. ${ }^{1}$ In the preface to Savage Life and Scenes, he described himself as a 'faithful describer' and a 'disinterested observer'. In focussing on people, his specific focus in New Zealand was ethnography - the gathering of information about humankind, which could then be further analysed by those working in the more highly trained field of ethnology. ${ }^{3}$ In 1849, in The Kafirs Illustrated, he wrote:

my aim has been to add something towards the history of the human race, that grand science of Ethnology which teaches us more and more, as we dive into the startling and instructive facts it daily unfolds to us, that "the noblest study of mankind is man. ${ }^{4}$

In his New Zealand works, Angas's identity as a natural historian and ethnographer was still evolving. It was implicit rather than explicit. In making claims that he had been careful, faithful and disinterested, and in describing himself as an observer and describer, however, Angas was aligning himself with a scientific discourse. This added significantly to his position as a reliable provider of information. This chapter focuses on Angas's descriptions and images of natural history and ethnography in Savage Life and Scenes and The New Zealanders. It examines the conclusions Angas came to, and the colonial knowledge he created, as he turned his categorising scientific gaze upon the people of New Zealand.

Appearing in The New Zealanders, amongst the portraits of individuals, was a plate entitled 'Typical Portraits of the New Zealanders' (see Fig. 14). It featured six head and shoulder images; two front-on and four in profile, two males and four females. In the text accompanying this image Angas described in detail the physical features of the 'typical

${ }^{1}$ George French Angas, New Zealanders Illustrated (London: Thomas McLean, 1847) Preface.

${ }^{2}$ George French Angas, Savage Life and Scenes in Australia and New Zealand: Being an Artist's Impressions of Countries and People at the Antipodes, vol. I (London: Smith, Elder and Co., 1847), vii, viii.

${ }^{3}$ Ernest Dieffenbach, "The Study of Ethnology," Journal of the Ethnological Society of London 1 (1848): 18.

${ }^{4}$ George French Angas, The Kafirs Illustrated (London: J. Hogarth, 1849), v. 
New Zealander'. Their hair was 'remarkably black, glossy, and luxuriant; occasionally it inclines to a brown colour... The hair of the men is often curly, but no approach to a woolly nature is discernible' and 'the eyes of both sexes are almost invariably of a dark hazel; their eyebrows are regular and well-defined, and their eyelashes strong'. Teeth, noses and mouths were all described. In general, the head was 'good and wellformed...both animal and intellectual faculties are strongly developed, and the facial angle is large'. ${ }^{5}$

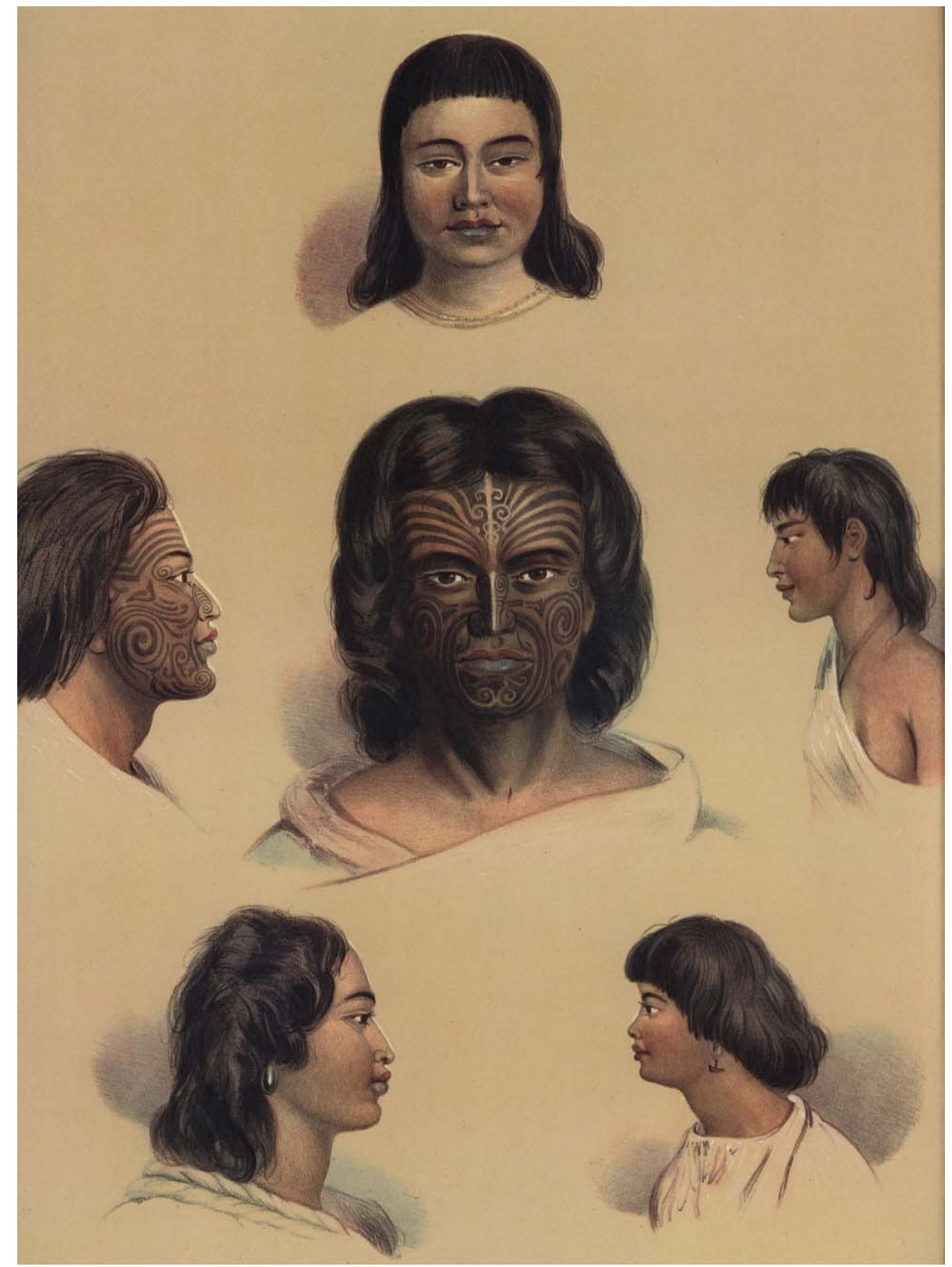

Figure 14: George French Angas, 'Typical Portraits of the New Zealanders,' lithographed by J.W. Giles, The New Zealanders Illustrated, 1847, Plate XLIX.

\footnotetext{
${ }^{5}$ Angas, New Zealanders Illustrated, Plate XLIX.
} 
'Typical Portraits' was a combination of the detailed examinations and broad generalisations which typified ethnology - close-up, intimate descriptions which were 'typical' examples of all Maori. In fact, the two male heads had full facial moko, which to Maori indicated the unique status and whakapapa, or ancestry, of the individual. Further, Maori were far from being a homogenous group; in 1844 the common identity of 'Maori' was in use, but was still a relatively new concept.

This form of detailed examination of 'the New Zealander' featured throughout Angas's work. The New Zealanders began with a section entitled 'General Remarks on the New Zealanders'. ${ }^{6}$ In Savage Life and Scenes three of the eighteen chapters across the two volumes were also 'general remarks' sections devoted purely to description of people and their customs; one on Maori, one on South Australian Aborigines, and one on New South Wales Aborigines. ${ }^{7}$ In these sections, Angas shifted his gaze beyond the surface of the body which was the subject of 'Typical Portaits'. In The New Zealanders his descriptions included the 'origin of the inhabitants of New Zealand,' their 'character', religion, sexual relations, clothing, architecture, musical traditions, and diet. Savage Life and Scenes, over thirty-seven pages, went into even greater detail and added further subjects such as descriptions of death ceremonies.

Most of the portraits in The New Zealanders were of named individuals and most of Savage Life and Scenes was about Angas and the encounters he was having. Sitting literally distinct from the rest of the text, corralled into separate chapters, the subject of these sections was no longer 'he' or 'she', but the non-individualised and homogenous 'they'. The 'I' narrative of the rest of his work was almost completely removed, replaced by a panoptical 'we'. Angas himself became all but invisible, surfacing only a couple of times to come down on one side of a theory or to emphasise that he had seen something with his own eyes. ${ }^{8}$ Neutral, disinterested and authoritative in tone, the implication was that the facts spoke for themselves; it was, without question, reliable information.

At the time that Angas was growing up, Enlightenment ideas of rationality and the importance of scientific enquiry were significant intellectual currents. People had a great

\footnotetext{
${ }^{6}$ Ibid., General Remarks.

${ }^{7}$ Angas, Savage Life and Scenes, 1847, I:78-116, 303-40; George French Angas, Savage Life and Scenes in Australia and New Zealand: Being an Artist's Impressions of Countries and People at the Antipodes, vol. II (London: Smith, Elder and Co., 1847), $210-33$.

8 Angas, Savage Life and Scenes, 1847, I:307.
} 
confidence in empirical truths and facts and a faith in progress. ${ }^{9}$ Science was a 'European knowledge-building enterprise of unprecedented scale and appeal' and attracted large amounts of energy and resources. ${ }^{10}$ As a child, as well as reading accounts of travellergatherers such as Alexander von Humboldt and Charles Waterton, Angas demonstrated a curiosity in the natural world, and an interest in collecting and categorising it. When the Angas family moved to Dawlish, on the coast of Devon, he started collecting shells. Conchology (the study of shells) was an interest he would pursue for the rest of his life.

In London, Angas pursued his interests in science and art simultaneously when he studied natural history illustration. He also engaged with London's proliferating world of scientific societies. ${ }^{11}$ Natural history societies such as the Zoological Society, the Royal Geographical Society and the Botanical Society of London often held public meetings and actively encouraged public participation, particularly from those who were intending to travel in the empire. ${ }^{12}$ A budding amateur scientist like Angas would have had no shortage of options for increasing his knowledge and making contacts. The links between these societies and empire were strong. As Europeans moved into parts of the world they had not experienced before, science, with its categorising and classifying, gave them a sense of control in otherwise uncertain environments.

The science most closely linked to empire was ethnology. The rapidly expanding 'Science of Man' helped Europeans make sense of the peoples they encountered in their empires, and their own place in the world. On 7 February 1843, six months before Angas set sail from Britain, the Ethnological Society of London was founded. Presenting the first paper at the Society's first meeting was Ernst Dieffenbach. ${ }^{13}$ In this paper, 'The Study of Ethnology', Dieffenbach advocated for the close study of the indigenous people of the world, arguing that it was possible to 'divide mankind into large families and subdivisions, and to establish descriptions of them, in as concise terms as the Botanist'. ${ }^{14}$ He called for travellers to become ethnographers. ${ }^{15}$ In this he was joining a wider call for travellers to be gatherers of scientific data. In 1839, the British Association for the Advancement of

\footnotetext{
${ }_{9}^{9}$ Bernard Cohn, Colonialism and Its Forms of Knowledge: The British in India (Princeton: Princeton University Press, 1996), 4. ${ }^{10}$ Mary Louise Pratt, Imperial Eyes: Travel Writing and Transculturation, 2nd ed. (London and New York: Routledge, 2008), $23,25$.

11 A surviving letter from Angas to his father from 1842 refers to Angas attending a meeting at the Royal Geographical Society. George French Angas to George Fife Angas, 17 March 1842, George Fife Angas Papers, PRG 174, Series 1, State Library of South Australia (SLSA).

${ }^{12}$ Lydia Wevers, Country of Writing: Travel Writing and New Zealand, 1809-1900 (Auckland: Auckland University Press, 2002), 4.

13 'Ethnological Society of London - Council,' Royal Anthropological Institute, Archive Contents,

www.therai.org.uk/archives-and-manuscripts/archive-contents/ethnological-society-of-london-council-a1, accessed on 9 Feb 2011.

${ }^{14}$ Dieffenbach, "The Study of Ethnology," 15.

15 Ibid., 16, 18.
} 
Science put out guidelines for travellers 'with a view to procure information respecting the different races of men, and more especially those which are in an uncivilised state. ${ }^{16}$ There is no evidence that Angas was involved with the Ethnological Society, but he did meet Dieffenbach at some point before the publication of Savage Life and Scenes. ${ }^{17}$

When Angas left England in April 1843 to travel to the antipodes he travelled with the desire to contribute to the 'knowledge building enterprise'. With the field instruments of a natural historian - insect net, forceps, collecting box, journal and sketchbook - he was well equipped to collect and categorise the world. As well as his ethnographical observations, Savage Life and Scenes and The New Zealanders contained descriptions relating to a wide range of fields - botany, zoology, entomology, and geography. When Angas described first sighting land on his way to New Zealand, 'the lofty summit of Mount Egmont [Mount Taranaki]', as well as describing its beauty, he provided measurements. It had been calculated to be 8839 feet tall, he informed his readers. ${ }^{18}$ In the week after Angas's arrival in Wellington, as he ventured into the surrounding areas, he described the 'teeming' woods, with 'tropical looking dragon trees (dracaena),' and 'the brilliant yellow clusters of the Edwardsii, and the large and star-like flowers of the clematis. ${ }^{19}$

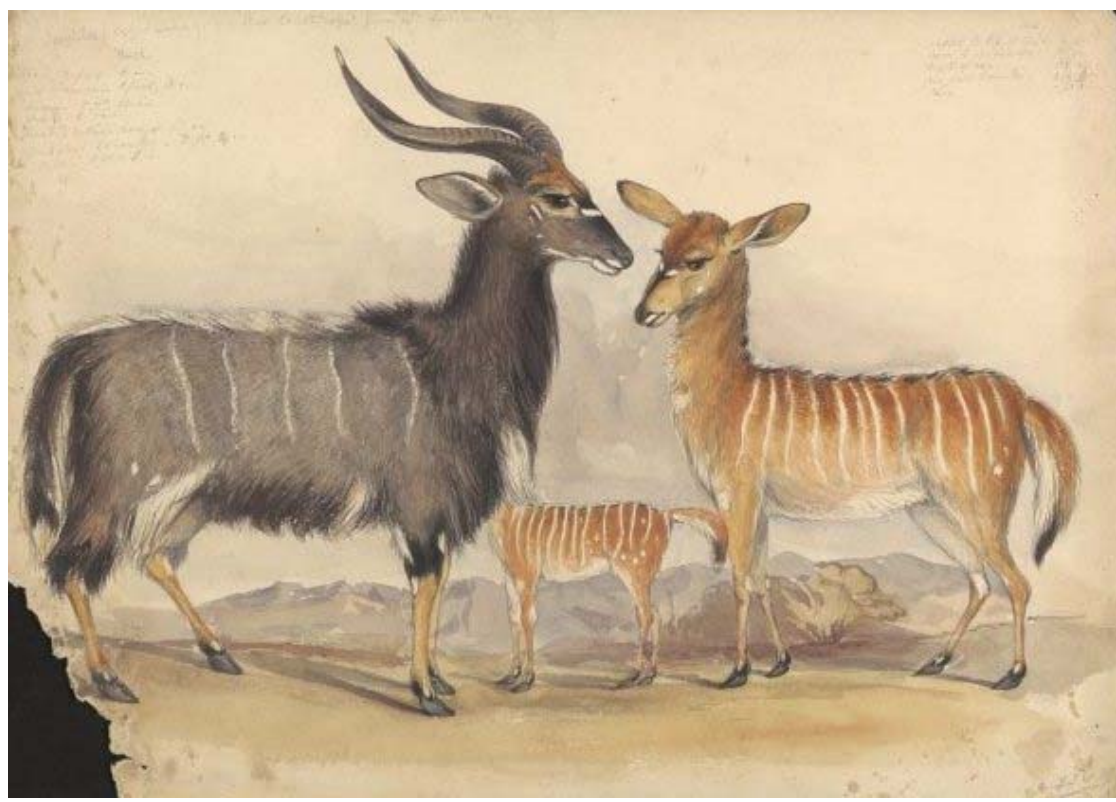

Figure 15: George French Angas, 'New Antilope[sic] from St Lucia Bay,' [Tragelaphas Angasi], 1847, watercolour, 252x353mm, Jose Calvo Collection, BOX A20, PIC R7100, NLA, http://nla.gov.au/nla.pic-an2887809

16 "Report," British Association for the Advancement of Science, Birmingham, 1839, quoted in Jacob W. Gruber, "Ethnographic Salvage and the Shaping of Anthropology," American Anthropologist 72, no. 6 (December 1970): 1294.

17 Angas, Savage Life and Scenes, 1847, I:229.

${ }^{18}$ Ibid., I:228, 229. This measurement was, in fact, an overestimate. Mt Taranaki is $8261 \mathrm{ft}$ high.

${ }^{19}$ Ibid., I:240, 289. 
Angas also made use of his insect net and collecting box. Soon after leaving Te Heuheu's pa at Te Rapa, Angas captured a butterfly that was later confirmed by 'my friend Edward Doubleday, Esq., of the British Museum' as being 'a new species of butterfly belonging to genus polyommatus. ${ }^{20}$ In Australia, he was the first European to catalogue several species of moth, including the Pasture Day moth (Apina callisto) and the Cremnophora angasii, which was named after him. ${ }^{21}$ In South Africa he described, and had named after him, a species of antelope - the Tragelaphas Angasi or Nyala (see Fig. 15). ${ }^{22}$ Some of the insects and plants he described became watercolours in his exhibitions and South Australia Illustrated included four 'entomology' and 'botany' lithographs (see Fig. 16). ${ }^{23}$
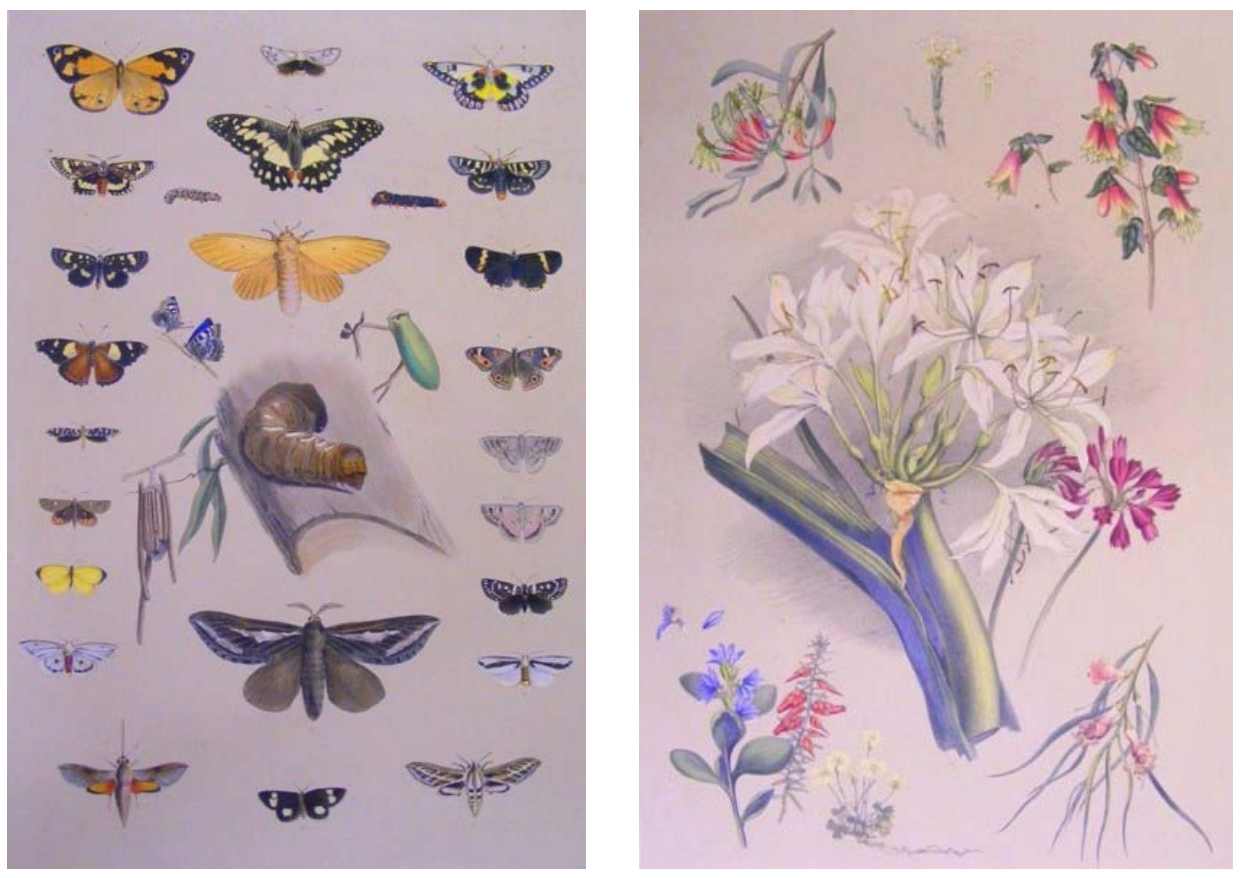

Figure 16: George French Angas, 'South Australian Entomology,' lithographed by W. Wing and George French Angas, 'South Australian Botany,' lithographed by George French Angas, South Australia Illustrated, 1846, Plates XLVIII, LV.

In capturing, drawing and describing the natural world, by investing it with Latinate names and inserting it into the Linnaean system of classification, and by channelling all this information back to London, Angas was participating in what Mary Louise Pratt has called the 'obsessive measurings' of Europeans within their empires. ${ }^{24}$ Despite the claims

\footnotetext{
20 Angas, Savage Life and Scenes, 1847, II:132.

${ }^{21}$ E.S. Nielsen, E.D. Edwards, and T.V. Rangsi, eds., Checklist of the Lepidoptera of Australia (Melbourne: CSIRO Publishing, 1996), 321; also Apina callisto (Angas, 1847), Lepidoptera Butterfly House, http://lepidoptera.butterflyhouse.com.au/agar/callist.html

22 Proceedings of the Zoological Society of London (London: The Zoological Society of London, 1848), 89-90; "George French Angas, F.L.S," The Little Journal I, no. 3, Typed Transcript, Mitchell Library (May 1884): 5.

${ }^{23}$ George French Angas, South Australia Illustrated (London: Thomas McLean, 1846) Plates XXVII, XLVIII, L, LV.

${ }^{24}$ Pratt, Imperial Eyes, 17.
} 
of Angas and others, it was far from being a 'disinterested' enterprise. In a poem published in 1874 that Angas wrote about the death of a natural historian in Australia, Angas demonstrated an understanding, if not a fully conscious one, of the nature of the science he was practicing:

Fair science pointed to a realm

Where Nature spread a field unknown;

He sought to reap her choicest fruits,

And make her treasures all his own. ${ }^{25}$

Reaping, making and owning - this was an assertive and highly appropriative venture. Nature was passive, 'spread', and waiting to be known. Angas also demonstrated the strongly gendered nature of scientific knowledge at the time. Active science was male, passive nature was female.

In his 'Typical Portraits' lithograph and the 'General Remarks' sections, Angas was turning his scientific gaze upon the people of New Zealand. He was making Maori passive objects waiting to be known. The power relations inherent in this sat awkwardly with his general representation of Maori as named individuals. Science, however, was a constructed knowledge system and its conclusions changed to fit different contexts. Angas's scientific categorisations of Maori aligned with the way he represented them in the rest of his narrative. ${ }^{26}$ Many studies have noted the role of ethnography and ethnology in creating categories of colonial difference. ${ }^{27}$ This was certainly the case, but the picture was also more complicated. The founders of the Ethnographical Society were humanitarians concerned about polygenisist theories that people from outside of Europe belonged to different species'. In his speech at the Society's first meeting Dieffenbach expressed the hope that ethnography would 'confirm by inductive science the cherished unity of mankind' and motivate people to treat with consideration all those who differ from us, instead of warring against individualities and forms which are not the same as

25 George French Angas, "To the Memory of Frederick Strange, the Naturalist, who was murdered by the savages of Percy Island", George French Angas, The Wreck of the "Admella" and Other Poems (London: Sampson Low, Marston, Low and Searle, 1874), 51.

${ }^{26}$ David Turnbull, "(En)-Countering Knowledge Traditions: The Story of Cook and Tupaia," in Science, Empire and the European Exploration of the Pacific, ed. Tony Ballantyne (Aldershot: Ashgate, 2004), 225.

${ }^{27}$ See for example Philippa Levine, "States of Undress: Nakedness and the Colonial Imagination," Victorian Studies 50, no. 2 (Winter 2008): 207; Pratt, Imperial Eyes, 31; Elizabeth Collingham, Imperial Bodies: The Physical Experience of the Raj, $c$. 1800-1947 (Cambridge: Polity, 2001), 6; Brian Wallis, "Black Bodies, White Science: Louis Agassiz's Slave

Daguerreotypes," American Art 9, no. 2 (Summer 1995): 38-61. 
our own. ${ }^{28}$ As with his use of the picturesque, ethnography added to the construction of affinities, and the support for the policy of amalgamation, in Angas's work. ${ }^{29}$

Ethnology was highly comparative, based on a 'finely graded hierarchy scaling in racial terms of the relative presence and absence of civilisation'.30 Civilisation, and its opposite, savagery, were two concepts that appeared consistently throughout Angas's work. When, in the 'Typical Portraits' lithograph, he described Maori as having an aquiline nose, hair that was not 'woolly', a large 'facial angle', and a complexion like a Spaniards, these were value-laden terms which signified degrees of savagery and civilisation and which would have been understood by Angas's intended audience. Angas ranked Maori high on the 'great chain of Being.'

Angas's colonial encounter was a transcolonial one and his assessment of Maori was made in an explicit and direct comparison with the Aborigines of South Australia, where he was just before New Zealand, and New South Wales, where he was just after. His positive assessment of Maori came at a high cost - a damning assessment of Aborigines. Angas's comparisons were made over a range of areas, in all of which he found Maori to be 'superior.' In The New Zealanders for example, Angas wrote, '[u]nlike the wandering Savages of New Holland, the New Zealanders are a people having social communities'. ${ }^{32}$

As demonstrated by the focus of 'Typical Portraits', signs of savagery and civilisation were highly embodied. The belief that difference could literally be read on the body 'achieved almost universal penetration into the Victorian consciousness'. ${ }^{33}$ There was a particular focus on the head and face, as being able to reveal moral and intellectual faculties. ${ }^{34}$ Featuring with particular potency in Angas's ethnographical descriptions was the female body. Women's bodies were 'a fulcrum by which the British measured and judged those they colonised. ${ }^{35}$ Aboriginal women, as described by Angas, were 'disproportionally small' and their skulls were 'elongated and very narrow, the development of the intellectual

\footnotetext{
${ }^{28}$ Dieffenbach, "The Study of Ethnology," 17, 26.

${ }^{29}$ James A. Boon, Affinities and Extremes: Crisscrossing the Bittersweet Ethnology of East Indies History, Hindu-Balinese Culture, and Indo-European Allure (Chicago: University of Chicago Press, 1990); Jeffrey Auerbach, "The Picturesque and the Homongenisation of Empire," The British Art Journal 5, no. 1 (Spring/Summer 2004): 53.

${ }^{30}$ Bronwen Douglas, "Science and the Art of Representing 'Savages': Reading 'Race' in Text and Image in South Seas

Voyage Literature," History and Anthropology 11, no. 2-3 (1999): 187.

31 Anne Salmond, Between Worlds: Early Exchanges Between Maori and Europeans, 1773-1815 (Auckland: Viking, 1997$), 404$.

32 Angas, New Zealanders Illustrated, General Remarks.

33 Sharrona Pearl, About Faces: Physiognomy in Nineteenth-century Britain (Cambridge and London: Harvard University Press, 2010), 2.

${ }^{34}$ Douglas, "Science and the Art of Representing 'Savages'," 187.

35 Philippa Levine, "Introduction: Why Gender and Empire?," in The Oxford History of the British Empire: Gender and Empire, ed. Philippa Levine (Oxford: Oxford University Press, 2004), 7; Angela Wanhalla, "Family, Community and Gender," in The New Oxford History of New Zealand, ed. Giselle Byrnes (South Melbourne: Oxford University Press, 2009), 455.
} 
organs being remarkably small. ${ }^{36}$ Maori women on the other hand, unless they were slaves, were 'well made' and 'delicately proportioned'. ${ }^{37}$

Angas also wrote that Maori women occupied 'a far higher position amongst the New Zealanders than they do in the aboriginal tribes of Australia'. ${ }^{38}$ Gender relations were crucial to Angas's assessment of degrees of savagery. 'One of the surest marks of the low position of the Australian savage in the scale of the human species,' he wrote, 'is the treatment of their women.' Aboriginal men, he elaborated, 'walk along with a proud and majestic air; behind them, crouching like slaves, and bearing heavy burdens on their backs, with their little ones astride on their shoulders, come the despised and degraded women'. ${ }^{39}$ In New South Wales, Angas wrote of the taking of a wife as being a process in which the chosen woman was kidnapped, beaten, and stupefied with blows which made her bleed. ${ }^{40}$ Once married, Aboriginal men had a 'custom of offering their wives to their friends when they visit them. ${ }^{41}$ Women in Australia, were, in short, 'degraded and despised to the lowest degree. ${ }^{32}$ In contrast, Maori 'domestic and social regulations' had 'attained to a very advanced state'. ${ }^{43}$

As a context-contingent system of knowledge, ethnographic assessments of indigenous peoples in contact zones were highly heterogeneous and contested. There were, therefore, alternative discourses that Angas could have drawn upon. In 1841, George Grey, Governor of South Australia when Angas was there, wrote that;

The Australians have been most unfairly represented as a very inferior race, in fact as one occupying a scale in the creation which nearly places them on a level with the brutes...certainly a more unfounded [prejudice] never had possession of the public mind. ${ }^{44}$

Another even more passionate voice for the rights of Aborigines was Reverend Lancelot Edward Threlkeld who had founded a London Missionary Society mission to the Awabakal people in New South Wales in 1825. He labelled the sciences that justified the

\footnotetext{
36 Angas, Savage Life and Scenes, 1847, I:79-80.

${ }^{37}$ Ibid., I:308.

38 Ibid., I:317.

39 Ibid., I:82.

40 Angas, Savage Life and Scenes, 1847, II:226.

${ }^{41}$ Angas, Savage Life and Scenes, 1847, I:93.

${ }^{42}$ Ibid., I:317.

${ }^{43}$ Ibid., I:304.

${ }^{44}$ George Grey, Journals of Two Expeditions of Discovery in North-west and Western Australia, During the Years 1837, 38 and 39, vol. II (London: T. and W. Boone, 1841), 367.
} 
labelling of Aborigines as inferior as a 'specious fallacy' and 'mental poison, which insidiously perverts the judgment'. ${ }^{45}$

Angas's work did in fact contain exceptions to the view that Aborigines were far down the scale of civilisation. He met one Aborigine who 'displayed a remarkably fine intelligent head, that would have puzzled phrenologists, had it been sent them as a type of the skulls of the New Holland savages. ${ }^{46} \mathrm{He}$ also met a group who he found to have 'fine figures and superior physical appearance.' One of them, the most 'noble' looking, 'trod the soil as though he were its possessor'. 'There was no fear... he stood before us in all the dignity of the savage - tall, erect, and strong., ${ }^{47}$ As James Belich observed in relation to assessments of Maori during the New Zealand wars, however, general rules 'absorbed, replaced or dominated the exceptions'. ${ }^{48}$ These exceptions were rare and did not affect Angas's overall assessment of the Aborigines as being very low down on the scale of savagery and civilisation.

In New Zealand, Maori had also been subjected to a range of assessments as to their degrees of savagery. In 1827, Augustus Earle had described Maori as 'cast in nature's perfect mould'. ${ }^{49}$ Charles Darwin on the other hand, visiting New Zealand in 1838 aboard the Beagle, wrote:

Looking at the New Zealander, one naturally compares him with the Tahitian; both belong to the same family of mankind. The comparison, however, tells heavily against the New Zealander. He may, perhaps be superior in energy, but in every other respect, his character is of a much lower order. One glance at their respective expressions brings conviction to the mind, that one is a savage, the other a civilised man..$^{50}$

Categorisations of savagery and civilisation were important because they translated into concrete issues such as rights to power and land. In Angas's ethnographical assessment of Maori he went as far as describing the 'typical' New Zealand head as frequently approaching 'in shape those of the most intellectual nations of Europe. ${ }^{31}$ The final lines of Angas's 'General Remarks upon the Natives of New Zealand' section in Savage Life and

\footnotetext{
${ }^{45}$ L. Threlkeld, Annual Report for 1838, Threlkeld Papers, Mitchell Library, pp. 5-6, quoted in Henry Reynolds, Dispossession: Black. Australians and White Invaders (Sydney: Allen \& Unwin, 1989), 111.

46 Angas, Savage Life and Scenes, 1847, I:125.

47 Ibid., I:72.

48 James Belich, The New Zealand Wars and the Victorian Interpretation of Racial Conflict (Auckland: Penguin Books, 1988), 334.

${ }^{49}$ Augustus Earle, A Narrative of a Nine Months' Residence in New Zealand in 1827 (London: Longman Rees, Orme, Brown, Green \& Longman, 1832), 206.

${ }^{50}$ Charles Darwin, The Voyage of the Beagle (London: Henry Colburn, 1839), 291. Accessed online at Project Gutenburg, www.gutenberg.org

51 Angas, New Zealanders Illustrated, Plate XLIX.
} 
Scenes made very strong claims for the rights of Maori. Maori [men], he wrote, see a 'gloomy future' for their children. He 'broods' and 'will fight for his children's land,' 'which among ourselves would be called patriotism'. Angas desired that 'things may be so ordered and arranged that the original possessors of the soil may enjoy all their former rights and privileges' ${ }^{52}$

Though a prominent narrative, the positive assessment of Maori was not the only narrative in Angas's work. His 'faithful describing' did not extend to consistent describing. In other parts of his work, he described Maori as 'barbarous,' and 'savage'. ${ }^{53}$ In this mode, Maori gender relations become very similar to those of Aborigines. Women were 'the doers of all the drudgery', having to 'work in the potato grounds, cook, carry wood and water, and bear heavy burdens when travelling. ${ }^{54}$ Maori women aged early because of 'early intercourse with the opposite sex'. ${ }^{55}$ At times, Angas's assessment of Maori moved so far down the hierarchy that they were animalised. At one pa Angas stopped at on the way to Te Heuheu's, to his 'great annoyance' he was greeted by a long and disagreeable tangi with 'howling like a hyaena[sic]', and 'housetop cats on moonlight nights'. ${ }^{56}$

Furthering the contradictions in Angas's work was that it was at this point in his journey in the central North Island where he found Maori to be the most barbarous, that he also found examples of the 'noble savage', the European trope of idealised 'others' untainted by civilisation and industrialisation. In Savage Life and Scenes, he described arriving in the regions around Lake Taupo. Exaggerating the isolation of the area he described it as 'the wildest part the interior', far from the influence of Europeans, 'whose...existence even, are but little known to dwellers on the coast'. Here the people were 'wild and subject to their old heathen customs'. Some of his descriptions of the people he met there were glowing, even rapturous. They were 'fine and good-looking' and the 'beauty and symmetry of the limbs of many of the youth, would render them admirable studies for the sculptor. ${ }^{57}$

Aside from the noble savage trope, Angas's inconsistent narratives did have a uniting theme; Maori were 'civilised' when they were engaging positively with European culture, and 'savage' when they were not. He wrote that Maori were an 'intelligent and superior race, worthy of holding a high position in the human family, and frequently by their noble

52 Angas, Savage Life and Scenes, 1847, I:338, 339.

${ }^{53}$ See for example ibid., I:261; Angas, Savage Life and Scenes, 1847, II:148.

54 Angas, New Zealanders Illustrated, General Remarks.

55 Angas, Savage Life and Scenes, 1847, I:311.

56 Angas, Savage Life and Scenes, 1847, II:108.

${ }^{57}$ Ibid., II:2, 111, 118. 
and consistent conduct, putting to blush the more educated and advanced European'. This was, however, because they had become Christian, given up their 'addiction' to cannibalism, and stopped living by their 'worst and wildest passions'. ${ }^{58}$

Unlike the more 'implicitly racist' categories that were in the process of developing in the 1840s, Angas's assessments of levels of savagery amongst Maori were more cultural rather than biological. ${ }^{59}$ His representation of Maori was largely that of the 'romantic savage', as described by Bernard Smith. ${ }^{60}$ Merging features of the noble and the ignoble savage, the romantic savage represented the 'childhood of man' and therefore needed to be educated by more 'advanced' and 'civilised' peoples. ${ }^{61}$ Angas described Maori as one of the 'savage races capable of civilisation' and as 'children of nature', 'gifted with high and superior faculties, which only require to be directed in a right channel. ${ }^{62}$ There was scope, therefore, for Maori to move up the scale.

The 'right channel' was European, but not universally European. Angas found some of the settlements in New Zealand to be channelling Maori in the wrong direction. They were 'contaminating' Maori, making them 'avaricious and indolent'. ${ }^{63}$ Angas found the 'worst' tribes in Kororareka in the far north, his final destination in New Zealand. 'Long contact with the lower classes of Europeans' had 'rendered the Nga Puis one of the worst and most troublesome tribes in the island.' Pomare, the chief, was 'reckless and drunken' and his pah is the resort of all manner of bad characters, presenting scenes of low debauch. ${ }^{94}$

Angas's belief that engaging positively with European culture made them civilised became inscribed on the bodies and intelligence of Maori. Tara (Tara-te-irirangi), a chief of Ngai Tai, for example, was 'well known and respected as the friend of Europeans, and a loyal adherent to the government'. Angas described him as having 'a fine intellectual head.' Using Tara as the example, Angas then extrapolated that all Maori were,

\footnotetext{
58 Angas, Savage Life and Scenes, 1847, I:338.

${ }^{59}$ Douglas, "Science and the Art of Representing 'Savages'," 192.

${ }^{60}$ Bernard Smith, European Vision and the South Pacific, 2nd ed. (Melbourne: Oxford University Press, 1989), 326.

61 Ibid., 330.

62 Angas, New Zealanders Illustrated, General Remarks; Angas, Savage Life and Scenes, 1847, I:325. This was considered to be one of the distinguishing characteristics between Polynesians, which included Maori, and Melanesians, which included Aborigines, at the time. Polynesians were described as open and curious and Melanesians were timeless and unchangeable, see Nicholas Thomas, "Melanesians and Polynesians: Ethnic Typifications Inside and Outside Anthropology," in Science, Empire and the European Exploration of the Pacific, ed. Tony Ballantyne (Aldershot: Ashgate, 2004), 314.

${ }^{63}$ Angas, Savage Life and Scenes, 1847, II:111; Angas, Savage Life and Scenes, 1847, I:236.

${ }^{64}$ Angas, Savage Life and Scenes, 1847, II:170.
} 
possessed of reasoning and reflecting powers, equal, if not superior even to those of Europeans. No civilized people can more carefully, patiently, and deliberately consider the merit of a subject or given line of conduct, than the New Zealanders, every action of whose life is almost the result of reflection. The New Zealander is to all intents and purposes an intellectual being, who might well stand the comparison with our own countrymen. ${ }^{65}$

Hurihanga, on the other hand, one of the 'heathen' priests who Angas found to be unreasonably antagonistic to the beneficial effects of Christianity, was 'one of the most villainous-looking old fellows I had ever beheld' with 'blood shot eyes'. ${ }^{66}$
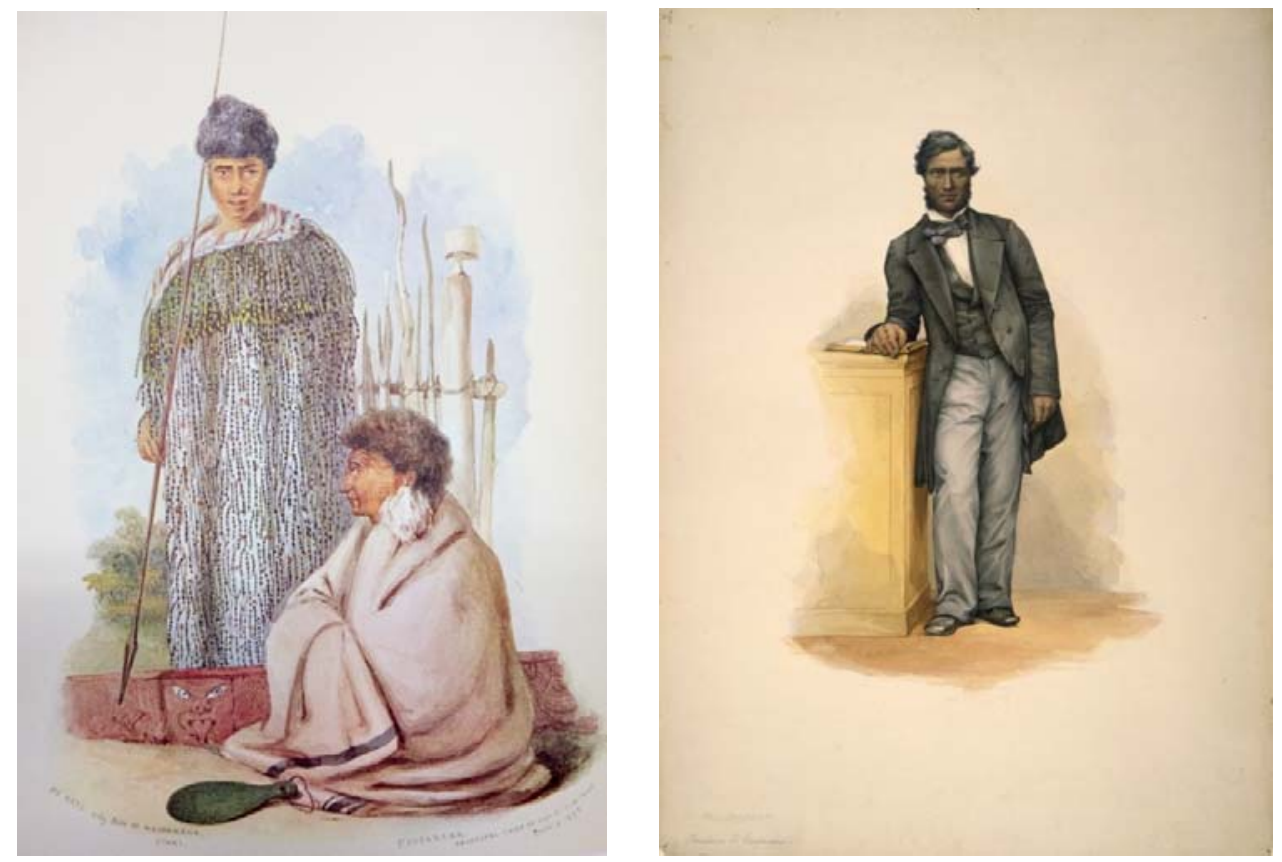

Figure 17: George French Angas, 'Te Rauparaha and Ko Katu', 1844, watercolour, 325x245mm, SAM, and 'Tamihana Te Rauparaha,' 1852, watercolour, 705x505mm, ATL.

Two paintings by Angas of Tamihana Te Rauparaha provide an example of the transformation towards a state of civilisation made manifest on the body (see Fig. 17). In 1844 when Angas was in Wellington, he painted Tamihana with his father, Te Rauparaha. He painted him again in 1852, either in Australia or England, when Tamihana was travelling with Archdeacon William Williams. ${ }^{67}$ In the first painting, Tamihana was in a Maori setting, wearing a cloak and holding a spear, while in the second he was in a British setting, wearing a suit and with his hand on a book. In the second painting, his nose and

65 Angas, New Zealanders Illustrated, Plate XXXIV.

${ }^{66}$ Angas, Savage Life and Scenes, 1847, I:262.

${ }^{67}$ Leonard Bell, Colonial Constructs: European Images of Maori, 1840-1914 (Auckland: Auckland University Press, 1992), 24;

See also National Library of New Zealand, "George French Angas, Tamihana Te Rauparaha, 1852,"

www.natlib.govt.nz. The library's notes state that the painting was done in London. Bell believes it was done in

Australia. 
lips have become narrower, and his face more 'Europeanised' in a way that eight years of aging does not explain. A companion piece to the 1852 painting, created at the same time, was subtitled 'a civilised and Christianised New Zealand chief. ${ }^{68}$

Angas's 'great chain of being' was fractured and multi-stranded but one aspect of it was immutable. At the top of the chain was British culture. Angas expressed doubts about some aspects of British culture, but he did not doubt its strength and overall superiority. He was certain that it would outlast all other cultures it came into contact with. When Angas sympathised with Maori for their attachment to their land, he wrote, 'he reasons thus:... as the black man of New South Wales, has dwindled away before the civilisation of the white man, so his nation...must pass into oblivion. ${ }^{69}$ Angas's ethnography was what has been described as 'salvage ethnography'. Like his use of the picturesque, this was the recording of a culture that he believed to be on the brink of major alteration. Angas explained that his decision to 'make carefully coloured drawings on the spot, of the most curious and characteristic specimens of Maori architecture and carving' was based on a 'desire to preserve memorials of the skill and ingenuity of a race of savages, who themselves ere long may pass away, and become, like their houses, matters of history. ${ }^{70}$

When Angas was being a natural historian and ethnographer in New Zealand, he was asserting a European system of knowledge over Maori systems of knowledge. He explicitly described Maori knowledge as 'deficient' and British knowledge as 'superior.' ${ }^{71}$ Though his categorisations were not as delineated as racial categories would become in the following years, they were still 'profoundly inegalitarian'. ${ }^{72}$ Angas's identity as a natural historian and ethnography was based on a discourse of neutrality and disinterestedness. His ethnographic assessments of Maori, however, were laden with issues of power. A culture that was changing and amalgamating was a culture that was less threatening. In Savage Life and Scenes, Angas wrote that '[a]s Christianity spreads, wars cease amongst the various tribes, and even those formerly the most belligerent are now quiet cultivators of the ground' ${ }^{73}$

${ }^{68}$ George French Angas, ‘Tamihana Te Rauparaha, 1852, watercolour, C-114-001, ATL; George French Angas, 'Tamihana Te Rauparaha: civilized and christianized New Zealand chief,' 1852, watercolour, C-114-002, ATL.

${ }^{69}$ Angas, Savage Life and Scenes, 1847, I:338.

${ }^{70}$ Ibid., I:267.

${ }^{71}$ Angas, Savage Life and Scenes, 1847, I:307, 339.

${ }^{72}$ Douglas, "Science and the Art of Representing 'Savages'," 187.

${ }^{73}$ Angas, Savage Life and Scenes, 1847, I:334. 
Angas's ethnographical descriptions and drawings were well received by audiences of his exhibitions. A review of his first exhibition wrote, 'Mr Angas' forte...doubtless lies in his figures. ${ }^{74}$ In London, his paintings were described as a "key to [New Zealanders] habits, customs and institutions. ${ }^{75}$ After Savage Life and Scenes and The New Zealanders were published Angas was widely recognised as a natural historian and ethnographer and he further cemented this reputation when he published The Kafirs Illustrated. After illness cut short his role as natural historian to a Turko-Persian Boundary Commission, he was no longer a travelling natural historian or ethnographer. ${ }^{76} \mathrm{He}$ continued, however, to engage in ethnographic projects based on the reputation he had gained. He wrote two books for the Society for Promoting Christian Knowledge: Australia in 1865, and Polynesia in $1866 .^{77}$ He also contributed to a book called The Natural History of Man in $1868 .^{78}$

Angas also continued to be a natural historian. He had a particular interest in shells and, though he rarely mentioned them in the published works discussed in this thesis, he catalogued many species of shell on his travels. He continued to do so for the rest of his life and gained numerous accolades for his contribution to the field. He is still known as the 'Father of Australian Conchology' ${ }^{79}$ It was partly his reputation in this field (and partly some well-timed donations from his father) that got him a position at the newly formed Australian Museum between 1852 and 1860. In his later life Angas was a member of various societies including the Linnaean Society of London, the Zoological Society of London and the Royal Geographical Society. He was also made a Correspondent of the Imperial Geological Museum of Vienna for his services to conchology in $1860 .{ }^{80}$

As with his roles of traveller and artist, Angas's role of natural historian/ethnographer helped him present himself as a neutral and reliable source of information about Maori. Also as with his roles of traveller and artist, the role of natural historian/ethnographer was inextricably bound to power relations in the newly formed colony. Angas was creating colonial knowledge. Physically separated out from the rest of his work, his ethnographic

74 'Mr George French Angas's Exhibition of Water Colour Paintings,' South Australian Register, 21 June,1845, p.2, col.f p.3, col.b.

75 Art Journal, 1846, viii, p. 140, quoted in Smith, European Vision and the South Pacific, 302.

76 'The Late George French Angas,' South Australian Register, 8 October 1886, p.7, col.h.

77 George French Angas, Australia: A Popular Account of Physical Features, Inhabitants, Natural History and Productions (London: Society for Promoting Christian Knowledge, 1865); George French Angas, Polynesia: a Popular Description of the Physical Features, Inbabitants, Natural History and Productions of the Islands of the Pacific. With an Account of Their Discovery, and of the Progress of Civilization and Christianity Amongst Them (London: Society for Promoting Christian Knowledge, 1866).

${ }^{78}$ John George Wood, The Natural History of Man (London: George Routledge \& Sons, 1868).

${ }^{79}$ John Tregenza, George French Angas: Artist, Traveller and Naturalist 1822-1886 (Adelaide: Art Gallery Board of South Australia, 1980), 29.

80 'South Australia,' The Sydney Morning Herald, 17 August 1860, p.5, col.d-e. 
assessments of Maori were also separated from the face-to-face encounters that characterised his time in New Zealand. The conclusion he came to as he categorised the people of New Zealand was that they were capable of civilisation and could be treated with respect, as long as they were engaging positively with the British and with British culture, and were not posing a threat to the colonial process that was underway. 


\section{'Aged but Vivid': Angas's Work into the Present}

On 16 September 2010 Shades of Grey: An exbibition of the life of Sir George Grey, politician, explorer and book lover...' opened at the Auckland Central City Library. The exhibition explored the 'life, career and interests' of Grey, Governor of New Zealand from 1845-53 and again from 1861-68. ${ }^{1}$ Amongst the books and documents illustrating episodes of Grey's life, were three items by George French Angas - a copy of The Kafirs Illustrated and two lithographs from South Australia Illustrated. Georgia Prince of the Library's Sir George Grey Special Collections department, and one of the curators of the exhibition, explained the choice to use Angas's works: they were useful references to Grey's time in those countries, but, above all, they were chosen because of their 'visual appeal.'

Angas's images had 'visual appeal' when they were first exhibited and published, and they have continued to do so ever since. While Shades of Grey used Angas's images from elsewhere to illustrate an aspect of New Zealand's history, it is his New Zealand images, and in particular the portraits, that are used extensively in the visual narration of New Zealand's history. The images exist now in various forms; the watercolours, the volumes of The New Zealanders and Savage Life and Scenes, and individual lithographs (because some of the subscribers to instalments of The New Zealanders Illustrated did not purchase the whole collection, and did not get them bound). These images have been preserved through time and have moved along 'networks of translation and appropriation,' developing rich careers. ${ }^{3}$ They have been repackaged and reprinted, and viewers and readers have engaged with them in different ways. They continue to be a visual record that contributes to understandings of New Zealand in the 1840s.

1 Auckland City Libraries, "Shades of Grey: Catalogue of selected items from the exhibition of the life of Sir George Grey - explorer, politician and book lover", curated by Iain Sharp, Kate de Courcy, Ian Snowdon, Robert Eruera and Georgia Prince, 16 September 2010-29 January 2011.

2 Personal Conversation with Georgia Prince, Sir George Grey Special Collections, Auckland City Libraries, 23 December 2010

3 James A. Secord, "Knowledge in Transit," Isis no. 95 (2004): 664. The idea of objects having careers comes from Leonard Bell, “Auckland's Centrepiece: Unsettled Identities, Unstable Monuments," in Rethinking Settler Colonialism: History and Memory in Australia, Canada, Aotearoa New Zealand and South Africa, ed. Annie Coombes (Manchester and New York: Manchester University Press, 2006), 102. 
After the fame and adventures of his early-twenties, Angas's life became rather more subdued. Despite the attention his exhibitions and publications received, and though he was able to capitalise on the role he had acquired of 'expert' about the places he had visited, he did not become a rich man. ${ }^{4}$ Angas's health, which had been unreliable since his serious illness in South Africa, worsened as he got older. In October 1875, aged fiftythree, he wrote a letter to his friend and fellow natural historian, Frederick George Waterhouse, complaining of the 'chronic rheumatism and acute neuralgia' he had experienced the past winter, and dreading what further suffering the coming winter might bring. ${ }^{5}$ A year later another letter revealed the financial difficulties Angas was having as he tried to fund a lifestyle he could not afford. He wrote to a Mr S.W. Silver, offering him the 'bargain' of ten of his South African watercolours for $f 30$. Angas wrote that he had hoped to keep them for his daughters, but was 'obliged to dispose of them to raise the means to give my wife and children a holiday at the seaside as the former is in very bad health and must have a change.' He expressed a belief that the images would be worth a lot upon his death. ${ }^{6}$

Angas died on 8 October 1886 aged sixty-four. His wife Alicia, writing to his brother John, described the cause of death as the 'breaking up of his left lung' after a long period of illness and increasing debilitation, worsened by 'the shock of dear Georgiana's sudden death'. ${ }^{7}$ Georgiana, his daughter, had died in childbirth four months earlier. ${ }^{8}$ In the same letter Alicia wrote, 'as you know dear John he hadn't much to leave.' According to the Oxford Dictionary of National Biography, Angas's total personal wealth upon his death was $£ 293$. His father, George Fife Angas, in stark comparison, had been worth $£ 885,700$ when he died in 1879. That was after he had transferred most of his investments to John in the 1860s. ' With Angas's death, his works moved finally and completely beyond his control. The watercolours that he still had in his possession were sold or distributed to family members. ${ }^{10}$

\footnotetext{
4 A. H \& A. W. Reed, Facsimile Editions of the Works of George French Angas (Sydney and Wellington: A. H. \& A. W. Reed, 1967), 5.

5 Angas to F.G. Waterhouse, 20 October 1875, Notting Hill, London, PRG 175/7, SLSA.

6 Angas to S. W. Silver, Notting Hill, 1 August 1876 - in Angas South African Watercolours box, SLSA.

7 Alicia Angas to John Howard Angas, 5 November 1886, PRG 175 Series 1/37, SLSA.

${ }^{8}$ George French Angas to John Brazier, 5 June 1886, A 732, Vol. 1, Mitchell Library, quoted in John Tregenza, George

French Angas: Artist, Traveller and Naturalist 1822-1886 (Adelaide: Art Gallery Board of South Australia, 1980), 29.

${ }^{9}$ Baigent, Elizabeth, 'Angas, George French', Oxford Dictionary of National Biography, vol 2, eds. HCG Matthew, Brian Harrison (Oxford: Oxford University Press, 2004) 144; P. A. Howell, 'Angas, George Fife (1789-1879)', Oxford Dictionary of National Biography, www.oxforddnb.com/view/article/537

10 'Angas, George French,' South Australian Museum, Adelaide, www.samuseum.sa.gov.au/angas-george-french-aa8, accessed on 11 May 2013.
} 
Angas's death went unnoticed by the New Zealand newspapers. Eight years after his death however, in 1894, a report was published in the Otago Witness about a 'fine collection of book [sic] relating to the Australian colonies, Tasmania, New Zealand and the South Sea Islands' on sale at Messrs Park, Reynolds and Company in Dunedin. Angas was listed as being one of the 'best known authors'. ${ }^{11}$ Savage Life and Scenes (both volumes) sold for f1 17s 6d. ${ }^{12}$ Over the years The New Zealanders in particular became an item that generated enthusiasm, headlines and large amounts of money. Prices paid for it often broke records. In 1933 it was described as 'one of the finest books on old New Zealand', ${ }^{13}$ in 1955 as a 'cornerstone' of collections of old New Zealand books, ${ }^{14}$ and in 1961 as 'the New Zealand book collector's classic piece'. ${ }^{15}$ It continues to hold this position today. In March 2005, for example, Webb's Auction House in New Zealand sold a copy of The New Zealanders for $\$ 31,000$, advertising it as a 'classic'. ${ }^{16}$

The 1961 article that described The New Zealanders as 'the New Zealand book collector's classic piece' also reported that it had just fetched 'a record' $£ 210$, the 'highest ever paid for any work on or about New Zealand at a book auction'. The article's primary interest was in the identity of the purchaser. This had not been revealed, but the auctioneers had 'given an assurance that the work will not be leaving New Zealand'. ${ }^{17}$ The need for this assurance to be given indicated the degree to which Angas's work was accruing significance for the 'nation'. It was a work to which had been attached an importance that it stayed within the geographical boundaries of New Zealand.

This aspect of Angas's work was also reflected in the journeys of items into libraries, art galleries and museums: the places of national memory and identity. One form this journey took was through donations from private collections. The gift of 14,000 items from George Grey's private collection which included a number of works by Angas, to the Auckland Free Public Library in 1887, was an early example. In 1906, a similar gift was made in Dunedin by the doctor and book collector, Thomas Morland Hocken. In an article in the Otago Witness detailing what had been gifted, The New Zealanders headed the 'Pictures and Illustrations' section. 'Amongst these must be mentioned G.F. Angas's

11 New Zealand and Australian Books. Otago Witness, 5 April 1894, p. 10.

12 'New Zealand and Australian Books,' Otago Daily Times, 30 March 1894, p. 3, and 'Sale of Rare Books, Otago Daily

Times, 2 April 1894, p. 2. This sale was also reported in the Taranaki Herald on 17 April 1894, p. 2.

13 'Rare Books, Recent Auction Prices,' Evening Post, 23 June 1933, p. 16.

14 'Rare Book Brings $f^{81}$ at Auction in Wellington', Taranaki Herald, 30 November 1955, Art File: George French Angas, Museum of New Zealand Te Papa Tongarewa.

15 'Record Bid for Rare Book', The Herald, 30 March 1961, Art File: George French Angas, Museum of New Zealand Te Papa Tongarewa.

${ }^{16}$ Webb's Auction House, 'George French Angas -The New Zealanders', 2005, www.webbs.co.nz/auction-item/thenew-zealanders-illustrated-1847, accessed 10 March 2011.

17 'Record Bid for Rare Book', The Herald. 
magnificent elephant folios' (a term sometimes used for a book between 23 and 25 inches high). ${ }^{18}$ In 1953 a copy of The New Zealanders was donated to the Alexander Turnbull Library by Queen Elizabeth II. ${ }^{19}$ Public institutions have also purchased Angas's works. The Alexander Turnbull Library, for example, has numerous works by Angas, many of which they purchased. In 1934, the library obtained a number of Angas's sketches and, though from a time when the library's records of acquisition were incomplete, they were most likely to have been purchased. ${ }^{20}$

In the early 1960s there was a resurgence of interest in Angas's works and the publishers A.H. and A.W. Reed initiated a project to reissue The New Zealanders. Edmund Bohan, in his 2005 biography of the 'House of Reed', described this reproduction of the 'almost legendary and very expensive' The New Zealanders as a 'remarkable publishing coup'. ${ }^{21}$ In conjunction with the Kyodo Printing Company in Japan, the project was undertaken with an extraordinary level of attention to detail and at a great deal of cost. Specific colours were recreated and paper was specially made so that the copy was as close to the original as possible. ${ }^{22}$ The risk inherent in creating such an expensive book paid off. In 1966 when it was finally published, the 750 copies had already sold out. ${ }^{23}$ Facsimile editions of South Australia Illustrated and Savage Life and Scenes followed in 1969. In 1979 Reed also published two smaller and cheaper, and therefore more accessible, collections of Angas's images, Maori Scenes and Portraits and Early Paintings of the Maori. ${ }^{24}$

A booklet produced by A.W. Reed in 1967 to promote the South Australia Illustrated reissue, explained why it had been felt that a reproduction of The New Zealanders would be a worthwhile exercise. Reed described the work as being important for 'students of early Maori history'. Angas's illustrations, he argued, 'cover a period where traditional Maori life and culture had not been entirely destroyed by the influence of European settlement'. They also portrayed 'a number of Maori personalities whose names have become

\footnotetext{
18 'The Hocken Collection, What it Consists Of,' Otago Witness, 8 August 1906, p. 32.

19 A. H \& A. W. Reed, Facsimile Editions of the Works of George French Angas, 6.

${ }^{20}$ Personal correspondence with Marian Minson, Curator, Drawings, Paintings and Prints, Alexander Turnbull Library,

17 March 2011.

${ }^{21}$ Edmund Bohan, The House of Reed, 1907-1983: Great Days in New Zealand Publishing (Christchurch: Canterbury

University Press, 2005), 139.

22 A. H \& A. W. Reed, Facsimile Editions of the Works of George French Angas, 7-12.

23 Ibid., 12.

${ }^{24}$ George French Angas, Maori Scenes and Portraits, ed. A. W. Reed (Wellington: A. H. \& A. W. Reed, 1979); George

French Angas, Early Paintings of the Maori, ed. A. W. Reed (Wellington: A. H. \& A. W. Reed, 1979). Following the success of the reproduction of Angas's works Reed carried out similar projects for Illustrations to Adventure in New Zealand by Edward Jerningham Wakefield (Wellington: Reed, 1968) and P. B. Maling, Early Charts of New Zealand (Wellington: Reed, 1969).
} 
historic'. ${ }^{25}$ Angas's stated intention to provide 'a more correct idea' had been brought into the twentieth century. He had become a primary source for those studying the period.

Interest sparked by the Reed reissues led a group of interested New Zealanders, including the art historian Gil Docking, to notice an exhibition of Angas's work in Adelaide in 1968. This included many of Angas watercolours from collections held by the South Australian Museum and the Art Gallery of South Australia. James Angas Johnston, the son of Angas's sister Rosetta, had bequeathed the watercolours to the Board of Governors of the Public Library, Art Gallery and Museum in 1902. The Art Gallery held them until 1912 when the works of 'ethnographic interest' were transferred to the Museum. ${ }^{26} \mathrm{New}$ Zealanders it seemed had been unaware of the existence of these watercolours, but they had now been 'discovered'. ${ }^{27}$

The result was Portraits of the New Zealand Maori Painted in 1844 edited by George Petersen and Hirini (Sidney) Moko Mead, and published by Reed in $1972 .{ }^{28}$ The excitement the discovery of this 'vivid and authentic...part of the historical record of New Zealand' generated was evident in Petersen's preface to the work:

now from the pile of aged but vivid watercolours appeared glimpses of old New Zealand as it was in actuality before it was changed for ever by the invading pakeha and became, in Angas's words, 'A land from shadowy forests won, In youthful beauty wedded to the sun.' Here also were proud old tattooed chiefs, clad in their ceremonial cloaks...emerging from the shadows and awaiting repatriation to their native lands. ${ }^{29}$

Petersen made the strongest claims for the historical and ethnographical significance, and the 'cardinal value', of Angas's work. What made it so important, Petersen argued was 'the painstaking accuracy, unsurpassed by any other artist working in New Zealand then or since, with which he reproduced the detail of his subject. ${ }^{30}$ He described Angas as having 'bequeathed to discerning men and women...the priceless gift of the fruits of his inquiring mind, keen observation, and artistic pen and brush. ${ }^{31}$ The evaluation of the watercolours as being more vivid and authentic than the lithographs also came to be reflected in the

25 A. H \& A. W. Reed, Facsimile Editions of the Works of George French Angas, 6.

26 'Angas - George French', South Australian Museum, www.samuseum.sa.gov.au/archives/collections/aa8

${ }^{27}$ Gil Docking to John Baily, 18 April 1986; R.D.J. Weathersbee to Gil Docking, 5 July 1968, George French Angas

File, Auckland Art Gallery Research Library (AAGRL)

${ }^{28}$ G.C. Petersen and S.M. Mead, eds., Portraits of the New Zealand Maori Painted in 1844 (Wellington: A. H. \& A. W. Reed, 1972).

${ }^{29}$ G.C. Peterson, "Preface," in Portraits of the New Zealand Maori Painted in 1844, ed. G.C. Petersen and S.M. Mead

(Wellington: A. H. and A. W. Reed, 1972), 10.

${ }^{30} \mathrm{Ibid}$.

31 Angas, Maori Scenes and Portraits, 2. 
prices they received at art auctions. In 1985 a watercolour of Nga Toenga, broke a record for a nineteenth-century New Zealand painting when it sold for $\$ 40,000 .^{32}$ In 2003 , the watercolour 'Apiwai te Kawau, Principal Chief of Ngati Whatua, and his nephew Rewiti, Orakei’ sold for $\$ 150,000 .{ }^{33}$

Mead's essay in Portraits of the New Zealand Maori was an example of Maori engaging with Angas's works. Mead, of Ngati Awa, was the first Professor of Maori at Victoria University of Wellington and was made a Distinguished Companion of the New Zealand Order of Merit for his services to Maori and to education in 2007. ${ }^{34}$ He described Angas as 'one of our most important sources of information on material culture in New Zealand in the early $1840 \mathrm{~s}^{35}{ }^{35}$ In recent years, arguably the most significant aspect of the 'networks of translation and appropriation' surrounding Angas's works has been Maori engagement with them, opening up new ways of exploring them and the past they depict.

In the preface to Portraits of the New Zealand Maori, Petersen wrote of the watercolours at the South Australian Museum 'awaiting repatriation to their native lands'. ${ }^{36}$ In Taupo, a project was instigated in 2009 that may eventually see this come to fruition. I interviewed one of the people involved in the project who wished to remain anonymous. She was a researcher at the Taupo Museum and a member of the Ngati Tuwharetoa Gallery Governance Group. In 2010 she spent time at the South Australia Museum in Adelaide, examining the watercolours and establishing which iwi the subjects belonged to.

As part of her application for the internship at the South Australian Museum, another member of the Gallery Governance Group described Angas's works as 'significant to Maori throughout the country'. They were 'prized and regarded as taonga or treasure', and had 'visual and spiritual connection to generations long past'. ${ }^{37}$ In an interview with me, the researcher elaborated on this aspect of the works. To her it was the spiritual connection, the energy transfer, that was formed between artist and subject in the moments when the portraits were made that was important. The watercolours still carry

\footnotetext{
32 New Zealand Herald, 1985 (no further information available), Art File: George French Angas, Museum of New Zealand Te Papa Tongarewa.

33 Webb’s Auction House, 'George French Angas - Apiwai te Kawau', 2003, www.webbs.co.nz/auction-item/apihai-tekawau-principal-chief-Ngati-whatua-and-his-nephew-rewiti-orakei-1844, accessed 10 March 2011.

34 'Professer Sir Hirini Moko Mead', Waitangi Tribunal Te Ropu Whakamana i te Tiriti o Waitangi: Tribunal Members, www.justice.govt.nz/tribunals/waitangi-tribunal/about/tribunal-members/professor-sir-hirini-moko-mead, accessed on 10 March 2014.

35 S.M. Mead, "Maori Material Culture in 1844," in Portraits of the New Zealand Maori Painted in 1844, eds. Petersen and Mead, 11.

${ }^{36}$ Peterson, "Preface," 10.

${ }^{37}$ Letter to South Australian Museum, 23 January 2009, Taupo, provided to me by a researcher at the Taupo Museum and member of the Ngati Tuwharetoa Gallery Governance Group, 18 February 2011. She wished to remain anonymous.
} 
the spirit of the subject from the moment at which the image was made. Angas's portraits are therefore living objects. ${ }^{38}$ In a Maori world view, time is less teleologically restricted than in European based knowledge systems. Images of ancestors enable the 'genealogical collapsing of time, symbolically bringing descendants face to face with their ancestral selves. ${ }^{39}$ The Ngati Tuwharetoa Ariki (Paramount Chief) in 2013, Tumu te Heuheu, a direct descendent of Te Heuheu Tukino II who Angas painted, leads his iwi alongside his ancestors.

Angas's role as a member of a colonising group, and as a part of a colonising project in its broadest sense, did present a challenge for the researcher. She had some concerns about the way he wrote about Maori and the position of superiority he took in his works. She also had concerns about the way that he was careless with details in his images, taking objects he had seen in different parts of New Zealand and that represented specific places and people, and incorporating them into imagery that was generically 'Maori', as he did in Plate XXL, 'The House of Hiwikau and the Falls of Kowaihi'. Overall however, the significance of the link to her past and to her ancestors outweighed these concerns. She did also see a level of respect in some of what Angas did in New Zealand. She pointed to the effort that Angas had gone to get his images, the energy that he had invested and the personal risk he had exposed himself to.

Paul Tapsell described taonga as having three components: mana, tapu and korero. The korero is the rituals, genealogical recitations and historical stories that go with the taonga. It is the medium by which all lore and knowledge are passed on. Korero, Tapsell argued, is the most important component of taonga. Taken out of New Zealand and passed around within European circles and institutions, Angas's portraits were separated from their korero. Angas's watercolours remain, for now, at the South Australian Museum, but the museum has made moves towards a more collaborative system of ownership with Maori. The korero has begun.

\footnotetext{
${ }^{38}$ Personal conversation with a researcher at the Taupo Museum and member of the Ngati Tuwharetoa Gallery Governance Group, 18 February 2011. The researcher wished to remain anonymous.

${ }^{39}$ Paul Tapsell, "Service after Death:The Art of Maori Leadership in Marae Contexts," in The Power of Portraiture:

Representing Leadership in New Zealand from 1840 to the Present, by Erin Griffey (Auckland: University of Auckland Business

School and David Ling Publishing, 2008), 19.
} 
In 1984 Donna Awatere, then a powerful voice for the Maori protest movement, challenged, 'who the hell gave British and European immigrants the right to take over another place, whether it is Zimbabwe, Azania or Aotearoa'. ${ }^{1}$ Britain's military and economic resources were crucial, but it was their discourses and forms of knowledge about themselves and the indigenous peoples and lands they encountered that gave them an imagined 'right'. George French Angas was part of the creation of these discourses and forms of knowledge. He was not a malicious individual, bent on the destruction of a people and the plunder of their lands. When he arrived in New Zealand, he was a young man of twenty-two with an adventurous and Romantic disposition. He had rebelled from the influential career laid out in front of him and chosen instead to travel to the other side of the world. Drawing, writing, categorising and describing, however, he was participating in the creation of colonial knowledge. Presenting himself as a 'disinterested observer' and a provider of a 'more correct idea', he actively positioned himself as a reliable source of neutral and legitimate information.

Angas travelled to, and produced works about, three sites of British settler colonialism New Zealand, South Australia and South Africa. The focus of this thesis has been his four month long encounter in New Zealand in 1844. From this time he produced a travelogue, Savage Life and Scenes and two visual collections, the watercolours and The New Zealanders Illustrated lithographs. This study has looked at his portraits and written descriptions of his encounter, exploring the ways that he represented the people of New Zealand and the colonial encounter that was taking place there. Angas's works were vivid and engaging and generated enthusiastic responses as they entered the public domain in 1845-7. Audiences were also enthusiastic about the way Angas had presented himself - the traveller, the artist and the natural historian/ethnographer. They approved of, and helped to form, Angas's disinterested, mild-mannered 'anti-conquest' narrative. They cemented his role as a producer of colonial knowledge.

Since their creation Angas's works, both the published books and the watercolours, have developed their own careers. In New Zealand, they have been bought and sold by private collectors, and many have entered the collections of museums and art galleries through various channels. Reissued and repackaged and used to illustrate history in displays and books, they continue to engage the imaginations of viewers and readers. They remain a

${ }^{1}$ Donna Awatere, Maori Sovereignty (Auckland: Broadsheet, 1984), 15. 
significant part of the way New Zealanders understand the period of the early 1840s, just after the signing of the Treaty of Waitangi.

A recent move in the historiography of New Zealand has been to interrogate colonial processes more closely. Tony Ballantyne argued that 'colonisation and its legacies continue to stand at the heart of New Zealand life'. ${ }^{2}$ Giselle Byrnes wrote, 'the means by which Europeans came to occupy New Zealand, together with what the conditions of continued occupancy might be, are among the most pressing concerns for New Zealanders in the early twenty-first century. ${ }^{3}$ In this context, this thesis has moved beyond the common narrative of Angas as an uninspiring artist overly influenced by the picturesque but a good ethnographer who provides a window onto the past. It has examined him and his works more closely, revealing the rich and complex story they tell.

In his presentations of himself, Angas was a traveller who was 'wandering' and 'rambling', unattached to and unsullied by any commercial enterprise. He was motivated by his Romantic impulses and his love of nature. He also actively 'penetrated' space, making detailed descriptions as he went and going to great lengths to get his information. As an artist, he presented himself as being able to provide more accurate information than could be given by 'mere description'. His portraits were biographical documents. As an ethnographer he cast a neutral and disinterested scientific eye over Maori. There were many crossovers between these categories and they combined to present an 'anticonquest' narrative of a benign and informative encounter.

Central to the creation of Angas's New Zealand works was the middle ground in which he operated. Upon his arrival in the British settlement of Wellington in August 1844 he met with Maori leaders, beginning the collaborative nature of his project of portrait gathering. Those who actively assisted his travelling, such as Kahoki in Wellington and Te Wherowhero in the Waikato, did so for their own reasons. Angas admired Maori enough to make named portraits of them and to go to great lengths and a deal of personal discomfort to obtain them. Some of the portraits included signatures of the subjects, extending the biographical elements of portraiture. In New Zealand at least, Angas was a humanitarian who argued that Maori as 'original possessors of the soil' should be able to 'enjoy all their former rights and privileges'.

2 Tony Ballantyne, Webs of Empire: Locating New Zealand's Colonial Past (Wellington: Bridget Williams Books, 2012), 11.

${ }^{3}$ Giselle Byrnes, Boundary Markers: Land Surveying and the Colonisation of New Zealand (Wellington: Bridget Williams Books, 2001), 1-2. 
Angas wrote that no country was 'more peculiarly interesting' than New Zealand. He was motivated to go to New Zealand by a widespread British interest in the humanitarian experiment that was happening there and the possibilities for the future of the settlement process. When Angas was travelling in 1844, the New Zealand Company had established the first formal British settlements, and the Wairau Affray and Hone Heke's attack on the flagpole at Kororareka, incidents which indicated the emerging tensions between Maori, the settlers and the government, had been widely publicised. People were interested to see what would happen in New Zealand. This thesis demonstrates the degree to which the contact zone remained a dynamic and interactive, even collaborative space in the years immediately following the Treaty. It flags the possibilities that remained at that time for alternative forms of relationship between Maori and Pakeha than those that eventuated.

Angas was, however, also a producer of colonial knowledge that implicitly advanced the project of colonisation. Despite his creation of portraits of individuals and his positive assessment of Maori individuals and despite the doubts he expressed about aspects of British and European culture, overall he had a strong sense of his 'Britishness'. He is an example of the remarkable confidence in the superiority of their own culture demonstrated by British people in colonial contact zones. In his publications, literally and figuratively distanced from the middle ground, his encounter was presented as an encounter with 'Savage Life and Scenes'. In them, his representations of Maori included people who were picturesque and entertaining, and passive objects to be described and categorised. They were to be best supported by a policy of amalgamation into British culture. For all that Angas's assessments were based on concerns about the impact colonisation had had on other indigenous peoples, they were still based on the belief that the British colonisation of New Zealand would be beneficial to Maori and that their culture had to change.

A theme of this thesis has been the gendered and embodied nature of Angas's encounter and works. From the way he talked about travelling - 'penetrating' the unknown - to his role as a privileged male traveller assessing the relative degrees of savagery and civilisation based on the status of women (with all the inherent ironies that this represents when women in Britain, unless they were Queen Victoria, were not allowed to own property or to participate in government) to the prevalence of alluring young women in his works, his was a gendered project. With his close examination of the Maori body for the purposes of gaining his correct idea, it was also an embodied project. Angas's descriptions and images 
of women who had European husbands and the children that came of these marriages was an example of the female body as site of colonisation.

Angas was particularly interested in the way the Maori body was clothed and covered. His discourses on this topic reflected the varied and contradictory nature of his narrative in general. He was fascinated by Maori cloaks and admired the skill and artistry that went into them but his interest was because he assumed that cloak-making was a dying art. He regretted the use of the European blanket. He approved of the combining of British and Maori forms of dress in the case of young women, finding the practice charming and attractive. In other instances he ridiculed Maori engagements with British clothes. Denying Maori the right to dress their bodies the way they wanted to without being judged, objectified or ridiculed, was sartorial colonisation.

In the years after Angas's time in New Zealand, and particularly from the late 1850s, the middle ground weakened. There was a general hardening of settler's attitudes towards Maori. If these settlers had read Angas's works they would have been challenged by many aspects of them. Other aspects of the works, however, had helped to pave the way for the assertion of British rights, the disavowal of the rights established in the Treaty and policies aimed at the crushing of Maori resistance. In their study of settler colonies, Tracey Banivanua-Mar and Penelope Edmonds argued that 'self-consciously benign sounding policies of assimilation, merging, absorption or protection' were the start of practices, or allowed the development of policies that abolished the rights and the lands of indigenous peoples. ${ }^{4}$ Te Wherowhero moved away from his belief that negotiation was the way to deal with Pakeha, and became the first Maori King and leader of a significant resistance movement. ${ }^{5}$

Angas's works continue to engage the interest of New Zealanders in the early twenty-first century. This is likely to continue. His images are one of the few visual depictions of the 1840s in existence. Of the portraits discussed in this thesis, those of Tara-te-irirangi, Te Wherowhero, George Thoms, E Wai and Kahoki feature as illustrations on Te Ara: The Encyclopaedia of New Zealand. His works are widely available to New Zealanders. In 2013, everyone in New Zealand with access to the internet can view Angas's published works in digital form through the University of Auckland's Early New Zealand Books online

\footnotetext{
${ }^{4}$ Tracey Banivanua-Mar and Penelope Edmonds, "Introduction: Making Space in Settler Colonies," in Making Settler Colonial Space: Perspectives on Race, Place and Identity, ed. Tracey Banivanua Mar and Penelope Edmonds (Basingstoke and New York: Palgrave Macmillan, 2010), 3.

${ }^{5}$ Claudia Orange, The Treaty of Waitangi (Wellington: Bridget Williams Books, 1992), 108.
} 
project. ${ }^{6}$ Physical copies of The New Zealanders, either of the original or the Reed facsimile edition, are available in libraries in all the country's major cities. Many of his watercolours, particularly the New Zealand portraits remain at the South Australian Museum, but many of them can be seen in Petersen and Mead's 1972 publication, Portraits of the New Zealand Maori Painted in $1844 .^{7}$

This thesis has barely scratched the surface of the investigations that could be made of Angas and his works. One of the most valuable contributions to extending understandings of Angas's works would be kaupapa Maori studies of the works and the encounters they represent. A comparative study that examines similarities and differences in his responses to each of the three settler colonies Angas visited would also be of significant value. Angas's works deserve to be part of an on-going discussion and debate which interrogates them thoughtfully and creatively.

Roger Blackley, in 2005, described New Zealand's colonial portraits as a treasure trove awaiting serious attention. ${ }^{8}$ This thesis has dipped into that trove and examined the works and the colonial encounter of one of New Zealand's first portrait artists, George French Angas. The body of work Angas created is a rich and valuable one. The works are sites of encounter, of conversation, of assertion and counter-assertion. Paying them serious attention reveals a fascinating story about a moment in space in time - New Zealand in 1844 - and demonstrates the complex nature of the creation of colonial knowledge.

\footnotetext{
${ }^{6}$ See www.enzb.auckland.ac.nz

${ }^{7}$ G.C. Petersen and S.M. Mead eds, Portraits of the New Zealand Maori Painted in 1844 (Wellington: A. H. and A. W. Reed, 1972).

${ }^{8}$ Roger Blackley, A Nation's Portraits, Art History Lecture Series 3 (Wellington: School of Art History, Victoria University of Wellington, 2005), 18, 44.
} 


\section{Primary Sources}

\section{Manuscripts}

National Library of Australia

George French Angas Papers, 1838-1877

Artists File: George French Angas

Jose Calvo Collection: George French Angas

State Library of South Australia

Angas Family, PRG 174 and 175

Auckland Art Gallery Research Library

Artists File: George French Angas

\section{Published}

Newspapers

Colonist

Daily Southern Cross

Evening Post

Illustrated London Times

New Zealand Herald

New Zealand Spectator and Cook's Strait Guardian

Otago Daily Times

Otago Witness

South Australia

South Australian Register

Sydney Morning Herald

Taranaki Daily Times

The New Zealander

$\underline{\text { Books and Articles }}$

A. H \& A. W. Reed. Facsimile Editions of the Works of George French Angas. Sydney and Wellington: A. H. \& A. W. Reed, 1967.

Angas, George French. A Ramble in Malta and Sicily, in the Autumn of 1841. London: Smith, Elder and Co., 1842.

Angas, George French. Australia: A Popular Account of Physical Features, Inhabitants, Natural History and Productions. London: Society for Promoting Christian Knowledge, 1865.

Angas, George French Maori Scenes and Portraits. Edited by A. W. Reed. Wellington: A. H. \& A. W. Reed, 1979.

Angas, George French New Zealanders Illustrated. London: Thomas McLean, 1847.

Angas, George French Polynesia. London: Society for Promoting Christian Knowledge, 1866.

Angas, George French Savage Life and Scenes in Australia and New Zealand: Being an Artist's Impressions of Countries and People at the Antipodes. Vol. I. London: Smith, Elder and Co., 1847.

Angas, George French Savage Life and Scenes in Australia and New Zealand: Being an Artist's Impressions of Countries and People at the Antipodes. Vol. II. London: Smith, Elder and Co., 1847.

Angas, George French South Australia Illustrated. London: Thomas McLean, 1846.

Angas, George French The Kafirs Illustrated. London: J. Hogarth, 1849. 
Angas, George French The Wreck of the "Admella" and Other Poems. London: Sampson Low, Marston, Low and Searle, 1874.

Dieffenbach, Ernest. "The Study of Ethnology." Journal of the Ethnological Society of London 1 (1848): 15-26.

Dieffenbach, Ernest, Travels in New Zealand, with Contributions to the Geography, Botany, and Natural History of That Country. Vol. I, II. Capper, 1974.

Earle, Augustus. A Narrative of a Nine Months' Residence in New Zealand in 1827. London: Longman Rees, Orme, Brown, Green \& Longman, 1832.

Grey, George. Journals of Two Expeditions of Discovery in North-west and Western Australia, During the Years 1837, 38 and 39. Vol. II, n.d.

Heaphy, Charles. Narrative of a Residence in Various Parts of New Zealand. London: Smith, Elder and Co., 1842.

Petersen, G.C. and Mead, S.M. (eds). Portraits of the New Zealand Maori Painted in 1844. Wellington: A. H. and A. W. Reed, 1972.

Proceedings of the Zoological Society of London. London: The Zoological Society of London, 1848.

Unknown, Report of the Parliamentary Select Committee on Aboriginal Tribes (British Settlements) with Comments by the "Aborigines Protection Society." London: William Ball and Hatchard \& Son, 1837.

Von Humboldt, Alexander, and Aimé Bonpland. Personal Narrative of Travels to the Equinoctial Regions of America, During the Years 1799-1804. Translated by Thomasina Ross. Vol. 1. London: Henry G. Bohn, 1852.

Wakefield, E.J. Adventure in New Zealand. Vol. I, II. II vols. London: William Clowes and Sons, 1845.

Waterton, Charles. Wanderings in South America, the North-West of the United States, and the Antilles, in the Years 1812, 1816, 1820 and 1824: with Original Instructions for the Perfect Preservation of Birds and For. Edited by L. Harrison Matthews. [1st ed., reprinted] : London: Oxford University Press, 1973.

\section{$\underline{\text { Secondary Sources }}$}

\section{Books}

Anderson, Patricia. The Printed Image and the Transformation of Popular Culture, 1790-1860. Oxford: Clarendon Press, 1991.

Andrews, Malcolm. The Search for the Picturesque: Landscape Aesthetics and Tourism in Britain, 17601800. Aldershot: Scolar Press, 1989.

Angas, George. Early Paintings of the Maori. Edited by A. W. Reed. Wellington: A. H. \& A. W. Reed, 1979.

Auerbach, Jeffrey. "The Picturesque and the Homongenisation of Empire." The British Art Journal 5, no. 1 (Spring/Summer 2004): 47-54.

Ballantyne, Tony, Orientalism and Race: Aryanism in the British Empire. Basingstoke: Palgrave Macmillan, 2002.

Ballantyne, Tony, Webs of Empire: Locating New Zealand's Colonial Past. Wellington: Bridget Williams Books, 2012.

Ballara, Angela. Iwi: the Dynamics of Maori Tribal Organisation from c.1769 to C.1945. Wellington: Victoria University Press, 1998.

Bayly, C. A. Empire and Information: Intelligence Gathering and Social Communication in India, 1780-1870. Cambridge and New York: Cambridge University Press, 1996.

Beaglehole, J.C. The Journals of Captain James Cook on His Voyages of Discovery. Vol. 2 'The Voyage of the Endevour, 1768-1771'. Cambridge: Cambridge University Press, 1955.

Belich, James. The New Zealand W ars and the Victorian Interpretation of Racial Conflict. Auckland: Penguin Books, 1988.

Bell, Leonard, Colonial Constructs: European Images of Maori, 1840-1914. Auckland: Auckland University Press, 1992.

Bell, Leonard, The Maori in European Art: a Survey of the Representation of the Maori by European Artists from the Time of Captain Cook to the Present Day. Wellington: A.H. \& A.W. Reed, 1980. 
Blackley, Roger, A Nation's Portraits. Art History Lecture Series 3. Wellington: School of Art History, Victoria University of Wellington, 2005.

Blythe, Martin. Naming the Other Images of the Maori in New Zealand Film and Television. Metuchen and London: The Scarecrow Press, 1994.

Bohan, Edmund. The House of Reed, 1907-1983: Great Days in New Zealand Publishing. Christchurch: Canterbury University Press, 2005.

Boon, James A. Affinities and Extremes: Crisscrossing the Bittersweet Ethnology of East Indies History, Hindu-Balinese Culture, and Indo-European Allure. Chicago: University of Chicago Press, 1990.

Briggs, Asa. The Age of Improvement, 1783-1867. London and New York: Longman, 1979.

Bright, Charles H. The Confidential Clerk: a Study of Charles Flaxman in South Australia and His Relationship with George Fife Angas. Adelaide: E.H. Bright, 1983.

Brown, Gordon H., and Hamish Keith. An Introduction to New Zealand Painting, 1839-1967. Auckland: David Bateman in association with Collins, 1969.

Byrnes, Giselle. Boundary Markers: Land Surveying and the Colonisation of New Zealand. Wellington: Bridget Williams Books, 2001.

Calefato, Patrizia. The Clothed Body. Oxford and New York.: Berg, 2004.

Chatterjee, Partha. The Nation and Its Fragments: Colonial and Postcolonial Histories. Princeton: Princeton University Press, 1993.

Clarke, Michael. The Tempting Prospect: a Social History of English Watercolours. London: Colonnade Books, British Museum Publications, 1981.

Cohn, Bernard. Colonialism and Its Forms of Knowledge: The British in India. Princeton: Princeton University Press, 1996.

Collingham, Elizabeth. Imperial Bodies: The Physical Experience of the Raj, c. 1800-1947. Cambridge: Polity, 2001.

Curtin, Philip D. The Image of Africa: British Ideas and Action, 1780-1850. London: Macmillan and Company Ltd, 1965.

Docking, Gil. Two Hundred Years of New Zealand Painting. Wellington: A.H. \& A.W. Reed, 1971.

Douglas, Bronwen, and Chris Ballard (eds). Foreign Bodies: Oceania and the Science of Race, 1750-1940. Canberra: ANU E Press, 2008.

Dunn, Michael. A Concise History of New Zealand Painting. Auckland: David Bateman, 1991.

Dutton, Geoffrey. White on Black: The Australian Aborigine Portrayed in Art. South Melbourne Vic.: Macmillan of Australia in association with the Art Gallery Board of South Australia, 1974.

Filer, David. Painting the Frontier: The Art of New Zealand's Pioneers. Auckland: David Bateman, 2009.

Fox, Aileen. Prehistoric Maori Fortifications in the North Island of New Zealand. Monograph - New Zealand Archaeological Association ; No. 6. Auckland: Longman Paul, 1976.

Grogan, Susan. Flora Tristan: Life Stories. London and New York: Routledge, 1998.

Hackforth-Jones, Jocelyn. Augustus Earle, Travel Artist: Paintings and Drawings in the Rex Nan Kivell Collection, National Library of Australia. London: Scolar Press, 1980.

Hall, Catherine. Civilising Subjects: Metropole and Colony in the English Imagination, 1830-1867. Cambridge: Polity, 2002.

Hayes, John. The Portrait in British Art. London: National Portrait Gallery, 1991.

Heartfield, James. The Aborigines' Protection Society: Humanitarian Imperialism in Australia, New Zealand, Fiji, Canada, South Africa, and the Congo, 1836-1909. New York: Columbia University Press, 2011.

Hilton, Boyd. The Age of Atonement: The Influence of Evangelicalism on Social and Economic Thought, 17951865. Oxford: Clarendon Press, 1988.

Hodder, Edwin. George Fife Angas: Father and Founder of South Australia. London: Hodder and Stoughton, 1891.

Howe, K.R. Nature, Culture, and History: The "Knowing" of Oceania. Honolulu: University of Hawaii Press, 2000.

Jones, Philip. Ocbre and Rust: Artefacts and Encounters on Australian Frontiers. Kent Town: Wakefield Press, 2007.

Keith, Hamish. The Big Picture: a History of New Zealand Art from 1642. Auckland: Godwit, 2007. King, Michael. The Penguin History of New Zealand: Illustrated. Auckland: Penguin, 2007.

Kisler, Mary. Angels and Aristocrats: Early European Art in New Zealand Public Collections. Auckland: Godwit, 2010.

Laidlaw, Zoe. Colonial Connections, 1815-45: Patronage, the Information Revolution and Colonial Government. Manchester and New York: Manchester University Press, 2005. 
Levine, Philippa. Prostitution, Race, and Politics: Policing Venereal Disease in the British Empire. New York: Routledge, 2003.

Lydon, Jane. Eye Contact: Photographing Indigenous Australians. Durham: Duke University Press, 2005.

McCarthy, Conal. Exhibiting Maori: a History of Colonial Cultures of Display. Oxford and New York: Berg, 2007.

Moon, Paul. The Newest Country in the World: a History of New Zealand in the Decade of the Treaty. Auckland: Penguin Books, 2007.

O’Brien, Patty. The Pacific Muse: Exotic Femininity and the Colonial Pacific. Seattle: University of Washington Press, 2006.

O’Malley, Vincent. The Meeting Place: Maori and Pakeha Encounters, 1642-1840. Auckland: Auckland University Press, 2012.

O’Neill, Sally. George Fife Angas. Melbourne: Oxford University Press, 1972.

Orange, Claudia. The Treaty of W aitangi. Wellington: Bridget Williams Books, 1992.

Pearl, Sharrona. About Faces: Physiognomy in Nineteenth-century Britain. Cambridge and London: Harvard University Press, 2010.

Pearson, David. A Dream Deferred: The Origins of Ethnic Conflict in New Zealand. Wellington: Allen \& Unwin, 1990.

Pointon, Marcia. Hanging the Head: Portraiture and Social Function in Eighteenth-century England. New Haven and London: Yale University Press, 1993.

Porter, Bernard. The Absent-minded Imperialists: Empire, Society, and Culture in Britain. Oxford and New York: Oxford University Press, 2004.

Pratt, Mary Louise. Imperial Eyes: Travel Writing and Transculturation. 2nd ed. London and New York: Routledge, 2008.

Reynolds, Henry. Dispossession: Black Australians and White Invaders. Sydney: Allen \& Unwin, 1989.

Robinson, Sidney K. Inquiry into the Picturesque. Chicago: University of Chicago Press, 1991.

Ross, Robert. Clothing: a Global History, or The Imperialists' New Clothes. Cambridge: Polity, 2008.

Salmond, Anne. Between Worlds: Early Exchanges Between Maori and Europeans, 1773-1815. Auckland: Viking, 1997.

Scott, Joan. Only Paradoxes to Offer: French Feminists and the Rights of Man. Cambridge: Harvard University Press, 1996.

Sharp, Iain. Heaphy. Auckland: Auckland University Press, 2008.

Smith, Bernard. European Vision and the South Pacific. 2nd ed. Melbourne: Oxford University Press, 1989.

Stoler, Ann Laura. Carnal Knowledge and Imperial Power: Race and the Intimate in Colonial Rule. Berkeley: University of California Press, 2002.

Tapsell, Paul. Maori Treasures of New Zealand: The Gilbert Mair Collection, Auckland War Memorial Museum Tamaki Paenga Hira. Auckland: David Bateman in association with Auckland War Memorial Museum Tamaki Paenga Hira, 2006.

Temple, Philip. A Sort of Conscience: The Wakefields. Auckland: Auckland University Press, 2002.

Thomas, Nicholas. Colonialism's Culture: Anthropology, Travel and Government. Cambridge: Polity Press, 1994.

Tobin, Beth Fowkes. Picturing Imperial Power: Colonial Subjects in Eighteenth-century British Painting. Durham: Duke University Press, 1999.

Tregenza, John. George French Angas: Artist, Traveller and Naturalist 1822-1886. Adelaide: Art Gallery Board of South Australia, 1980.

Walker, Ranginui. Ka Whawhai Tonu Matou, Struggle Without End. 2nd ed. Auckland: Penguin Books, 2004.

Wanhalla, Angela. In/visible Sight: The Mixed-descent Families of Southern New Zealand. Wellington: Bridget Williams Books, 2009.

West, Shearer. Portraiture. Oxford: Oxford University Press, 2004.

Wevers, Lydia. Country of Writing: Travel Writing and New Zealand, 1809-1900. Auckland: Auckland University Press, 2002.

White, Richard. The Middle Ground: Indians, Empires, and Republics in the Great Lakes Region, 1650 1815. Cambridge: Cambridge University Press, 1991.

Wilson, Kathleen. The Island Race: Englishness, Empire, and Gender in the Eighteenth Century. London and New York: Routledge, 2003.

Wolfe, Patrick. Settler Colonialism and the Transformation of Anthropology: The Politics and Poetics of an Ethnographic Event. London and New York: Cassell, 1999. 
Wolfe, Richard. New Zealand Portraits. Auckland: Viking, 2008.

Wood, John George. The Natural History of Man. London: George Routledge \& Sons, 1868.

\section{Chapters and articles}

Andrews, Jonathan. "The (Un)Dress of the Mad Poor in England, c.1650-1850. Part 1." History of Psychiatry 18, no. 5 (2007): 5-24.

Auerbach, Jeffrey. "The Picturesque and the Homongenisation of Empire." The British Art Journal 5, no. 1 (Spring/Summer 2004): 47-54.

Ballantyne, Tony. "Introduction." In Science, Empire and the European Exploration of the Pacific, edited by Tony Ballantyne, xv-xxxv. Aldershot: Ashgate, 2004.

Ballantyne, Tony, "The Changing Shape of the Modern British Empire and Its Historiography." The Historical Joumal 53, no. 2 (June 2010): 429-452.

Ballantyne, Tony, "What Difference Does Colonialism Make?: Reassessing Print and Social Change in an Age of Global Imperialism." In Agent of Change: Print Culture Studies after Elizabeth L. Eisenstein, edited by Sabrina Baron, Eric N. Lindquist, and Eleanor F. Shevlin, 342-352. Amherst and Washington D.C.: University of Massachusetts Press in association with the Center for the Book Library of Congress, 2007.

Ballantyne, Tony, and Antoinette Burton. "Introduction: The Politics of Intimacy in an Age of Empire." In Moving Subjects: Gender, Mobility, and Intimacy in an Age of Global Empire, edited by Tony Ballantyne and Antoinette Burton, 1-28. Urbana: University of Illinois Press, 2009.

Ballantyne, Tony, and Brian Moloughney. "Introduction: Angles of Vision." In Disputed Histories: Imagining New Zealand's Pasts, edited by Tony Ballantyne and Brian Moloughney, 9-24. Dunedin: Otago University Press, 2006.

Banivanua-Mar, Tracey, and Penelope Edmonds. "Introduction: Making Space in Settler Colonies." In Making Settler Colonial Space: Perspectives on Race, Place and Identity, edited by Tracey Banivanua Mar and Penelope Edmonds, 1-24. Basingstoke and New York: Palgrave Macmillan, 2010.

Barringer, Tim, Geoff Quilley, and Douglas Fordham. "Introduction." In Art and the British Empire, edited by Tim Barringer, Geoff Quilley, and Douglas Fordham. Manchester: Manchester University Press, 2007.

Bassett, Judith. "Impotent Autocrats: 1840-1860." In The People and the Land: An Illustrated History of New Zealand, 1820-1920: Te Tangata Me Te Whenua, edited by Judith Binney, Judith Bassett, and Erik Olssen, 57-76. Wellington: Bridget Williams Books, 1993.

Bell, Leonard. “Auckland's Centrepiece: Unsettled Identities, Unstable Monuments.” In Retbinking Settler Colonialism: History and Memory in Australia, Canada, Aotearoa New Zealand and South Africa, edited by Annie Coombes, 100-120. Manchester and New York: Manchester University Press, 2006.

Binney, Judith. "Kawanatanga and Rangatiratanga: 1840-1860." In The People and the Land: An Illustrated History of New Zealand, 1820-1920: Te Tangata Me Te Whenua, edited by Judith Binney, Judith Bassett, and Erik Olssen, 77-97. Wellington: Bridget Williams Books, 1993.

Blackley, Roger, "The Portraits of Joseph Merrett." Art New Zealand Number 56 (Spring 1990): 82-85, 111.

Byrnes, Giselle, "Introduction: Reframing New Zealand History." In The New Oxford History of New Zealand, edited by Giselle Byrnes, 1-18. South Melbourne: Oxford University Press, 2009.

Byrnes, Giselle, and Catharine Coleborne. "Editorial Introduction: The Utility and Futility of 'the Nation' in Histories of Aotearoa New Zealand." New Zealand Journal of History 45, no. 1 (April 2011): 1-14.

Callaway, Helen. "Dressing for Dinner in the Bush: Rituals of Self-Definition and British Imperial Authority." In Dress and Gender: Making and Meaning in Cultural Contexts, edited by Ruth Barnes and Joanne B. Eicher, 232-247. Paperback ed. Providence: Berg, 1997.

Clark, Steve. "Introduction." In Travel Writing and Empire: Postcolonial Theory in Transit, edited by Steve Clark, 1-28. London and New York: Zed Books, 1999. 
Cohn, Bernard S. "Cloth, Clothes and Colonialism: India in the Nineteenth Century." In Cloth and Human Experience, edited by Annette Weiner and Jane Schneider, 303-354. Washington: Smithsonian Institution Press, 1989.

Douglas, Bronwen. 'Science and the Art of Representing 'Savages': Reading 'Race' in Text and Image in South Seas Voyage Literature." History and Anthropology 11, no. 2-3 (1999): 157201.

Dunn, Michael, "Some Aspects of Portraiture of the Maori." In Face Value: A Study in Maori Portraiture, edited by L.C. Lloyd, no page numbers. Dunedin: Dunedin Public Art Gallery, 1975.

Gibbons, Peter. "Cultural Colonization and National Identity." New Zealand Journal of History 36, no. 1 (April 2002): 5-17.

Gibbons, Peter, "The Far Side of the Search for Identity." New Zealand Journal of History 37, no. 1 (April 2003): 38-49.

Mona Gordon, 'The Early Artists of New Zealand - Angas...The Man Who Was Just In Time - II,' The New Zealand Railways Magazine 15, no. 1 (April 1940): 21-23

Gruber, Jacob W. "Ethnographic Salvage and the Shaping of Anthropology." American Anthropologist 72, no. 6 (December 1970): 1289-1299.

Hall, Catherine, "Introduction: Thinking the Postcolonial, Thinking the Empire." In Cultures of Empire: Colonizers in Britain and the Empire in the Nineteenth and Twentieth Centuries: a Reader, edited by Catherine Hall, 1-33. New York: Routledge, 2000.

Hall, Catherine, "Of Gender and Empire: Reflections on the Nineteenth Century." In The Oxford History of the British Empire: Gender and Empire, edited by Philippa Levine, 46-76. Oxford: Oxford University Press, 2004.

Hosking, Rick. "The Privileges of Mobility: George French Angas's Representations of Indigenous People in Savage Life and Scenes and His Debt to 'Learned Friend' William Cawthorne." Studies in Travel Writing 11 (2007): 15-35.

Hulme, Peter, and Youngs. "Introduction." In The Cambridge Companion to Travel Writing, edited by Peter Hulme and Tim Youngs. Cambridge: Cambridge University Press, 2002.

Jones, Philip "George French Angas: Colonial Artist at Large." In Crossing Cultures: Conflict, Migration and Convergence: The Proceedings of the 32nd International Congress of the History of Art, edited by Jaynie Anderson and Comite international d'histoire de l'art., 322-327. Carlton: Miegunyah Press Melbourne University Publishing, 2009.

Klopper, Sandra. "A Man of Splendid Appearance: Angas' Utimuni, Nephew of Chaka the Late Zulu King." African Studies 53, no. 2 (1994): 2-24.

Lambert, David, and Alan Lester. "Imperial Spaces, Imperial Subjects." In Colonial Lives Across the British Empire: Imperial Careering in the Long Nineteenth Century, edited by David Lambert and Alan Lester, 1-31. Cambridge and New York: Cambridge University Press, 2006.

Lepore, Jill. "Historians Who Love Too Much: Reflections on Microhistory and Biography." The Journal of American History 88, no. 1 (June 2001): 129-144.

Levine, Philippa. "Introduction: Why Gender and Empire?" In The Oxford History of the British Empire: Gender and Empire, edited by Philippa Levine, 1-13. Oxford: Oxford University Press, 2004.

Levine, Philippa "States of Undress: Nakedness and the Colonial Imagination." Victorian Studies 50, no. 2 (Winter 2008): 189-219.

Liu, James H., Tim McCreanor, Tracey McIntosh, and Teresia Teaiwa, eds. "Introduction: Constructing New Zealand Identities." In New Zealand Identities: Departures and Destinations, 11-20. Wellington: Victoria University Press, 2005.

Macdonald, Charlotte. "Intimacy of the Envelope: Fiction, Commerce, and Empire in the Correspondence of Friends Mary Taylor and Charlotte Bronte, c. 1845-55." In Moving Subjects: Gender, Mobility, and Intimacy in an Age of Global Empire, edited by Tony Ballantyne and Antoinette Burton, 89-109. Urbana: University of Illinois Press, 2009.

Mahuika, Nepia. "'Closing the Gaps': From Postcolonialism to Kaupapa Maori and Beyond.” New Zealand Journal of History 45, no. 1 (2011): 15-32.

Minson, Marian. "Promotional Shots: The New Zealand Company's Paintings, Drawings and Prints of Wellington in the 1840s and Their Use in Selling the Colony." In Edward Gibbon Wakefield and the Colonial Dream: a Reconsideration., edited by The Friends of the Turnbull Library, 159-166. Wellington: Friends of the Turnbull Library and GP Publications, 1997. 
Peterson, G.C. "Preface." In Portraits of the New Zealand Maori Painted in 1844, edited by G.C. Petersen and S.M. Mead. Wellington: A. H. and A. W. Reed, 1972.

Rountree, Kathryn. "Re-Making the Maori Female Body: Marianne William's Mission in the Bay of Islands." The Journal of Pacific History 35, no. 1 (June 2000): 49-66.

Rubiés, Joan Pau. "Travel Writing and Ethnography." In The Cambridge Companion to Travel Writing, edited by Peter Hulme and Tim Youngs, 242-260. Cambridge: Cambridge University Press, 2002.

Secord, James A. "Knowledge in Transit." Isis no. 95 (2004): 654-672.

Sinclair, Keith. "Why Are Race Relations in New Zealand Better Than in South Africa, South Australia or South Dakota." New Zealand Journal of History (1971): 121-127.

Smith, Terry. "Visual Regimes of Colonization: Aboriginal Seeing and European Vision in Australia." In The Visual Culture Reader, edited by Nicholas Mirzoeff, 484-494. London and New York: Routledge, 2002.

Tapsell, Paul, "The Flight of Pareraututu: An Investigation of Taonga from a Tribal Perspective." The Journal of the Polynesian Society 106, no. 4 (December 1997): 323-374.

Thomas, Nicholas, "Melanesians and Polynesians: Ethnic Typifications Inside and Outside Anthropology." In Science, Empire and the European Exploration of the Pacific, edited by Tony Ballantyne, 297-319. Aldershot: Ashgate, 2004.

Turnbull, David. “(En)-Countering Knowledge Traditions: The Story of Cook and Tupaia." In Science, Empire and the European Exploration of the Pacific, edited by Tony Ballantyne, 225-246. Aldershot: Ashgate, 2004.

Unknown. "George French Angas, F.L.S." The Little Journal I, no. 3. Typed Transcript, Mitchell Library (May 1884): 230-234.

Viljoen, Russel. “'Sketching the Khoikhoi': George French Angas and His Depiction of the Genedendal Khoikhoi Characters at the Cape of Good Hope, c. 1847." South African Journal of Art History 22, no. 2 (2007): 277-290.

Wallis, Brian. "Black Bodies, White Science: Louis Agassiz's Slave Daguerreotypes." American Art 9, no. 2 (Summer 1995): 38-61.

Wanhalla, Angela. "Family, Community and Gender." In The New Oxford History of New Zealand, edited by Giselle Byrnes, 447-464. South Melbourne: Oxford University Press, 2009.

Wilson, Kathleen. "Empire, Gender and Modernity in the Eighteenth Century." In The Oxford History of the British Empire: Gender and Empire, edited by Philippa Levine, 14-45. Oxford: Oxford University Press, 2004.

Wilson, Kathleen. "Introduction: Histories, Empires and Modernities." In A New Imperial History: Culture, Identity, and Modernity in Britain and the Empire, 1660-1840, edited by Kathleen Wilson, 1-26. Cambridge and New York: Cambridge University Press, 2004.

Wolfe, Patrick. "History and Imperialism: A Century of Theory, from Marx to Postcolonialism." The American Historical Review 102, no. 2 (April 1997): 388-420.

Woodall, Joanna. "Introduction: Facing the Subject." In Portraiture: Facing the Subject, edited by Joanna Woodall, 1-25. Manchester and New York: Manchester University Press, 1997.

Theses

Campbell, Susan Mary. "George French Angas: 'Describing, Prescribing, Inscribing," MA, University of Auckland, 2000.

Pollock, Jacob. "From Colony to Culture: Historiographical Discourse and Historical Identity in Aotearoa/New Zealand, 1883-2003." MA, University of Auckland, 2005.

Salesa, Damon Ieremia. "Race Mixing: A Victorian Problem in Britain and New Zealand, 1830s1870.” PhD, Faculty of Modern History, University of Oxford, 2000. 